\title{
PALEOHYDROLOGY OF THE INCAMISANA WATERSHED AND MOUNTAIN CANAL SYSTEM AT OLLANTAYTAMBO, PERU
}

\author{
A Thesis \\ Presented to \\ The faculty of the School of Engineering and Applied Science \\ University of Virginia
}

\author{
in partial fulfillment \\ of the requirements for the degree \\ Master of Science
}

by

Jenna N. Sollner

December 2012 


\section{Approval Sheet}

This Thesis is submitted in partial fulfillment of the requirements for the degree of Master of Science (Civil Engineering)

Jenna N. Sollner

Author

This thesis has been read and approved by the examining committee:

Dr. Richard Miksad (Advisor)

Dr. Joanna C. Curran

Dr. Thomas T. Baber

Eliot Wong, E.I.T, CFM

Emily Becker, P.E.

Kenneth Wright, P.E.

Accepted for the School of Engineering and Applied Science:

Dr. James Aylor

Dean, School of Engineering and

Applied Science

December 2012 


\section{Additional Thesis Supervisor}

I would like to thank Dr. Arminda Gibaja Oviedo, the Chief Archaeologist, from the National Institute of Culture at Cuzco, or INC. She led excavations in the research area, specifically at the Incamisana at Ollantaytambo, Peru from 1980-1982, and rediscovered the Incamisana. She acted as a supervisor for this project. She was present for the field studies, and was the archaeological authority for this project. Her wisdom and expertise in the area of Ollantaytambo made this project a success. I cannot thank her enough for all of the time and effort she put into the field studies. 


\section{Acknowledgements}

I would first like to thank my advisor, Dr. Richard Miksad. Thank you for giving me the opportunity to earn my Master's Degree under your supervision, and for providing me with your infinite wisdom and encouragement along the way. You have been a wonderful mentor throughout this experience and your motivation has been a driving force.

Thanks to my committee members from the UVa Civil Engineering Department, Dr. Joanna Curran and Dr. Thomas Baber.

Special thanks also to my committee members from Wright Water Engineering, Eliot Wong and Emily Becker, as well as Ken Wright. You all went above and beyond to help with any problem I encountered along this journey, and I cannot thank you all enough for providing me with the tools I needed to complete this project.

Luke Wildfire, although you did not technically serve on the committee, your insight and suggestions were always valuable to me and this research project. I thank you for all the time you put in with technical aspects of the project as well as the fieldwork. And, to Luke, Tosh Bance, and Spencer Lacy, your mountain climbing skills made this project what it was. I am so grateful that you were all so willing to hike anywhere and everywhere.

I would also like to thank my parents and my brother, for always supporting me in everything that I do. You all have always encouraged me and had faith in me, for that I am ever thankful. I am also grateful for Jeff, my other half, who supported me and believed in me even when I didn't believe in myself. 


\section{Table of Contents}

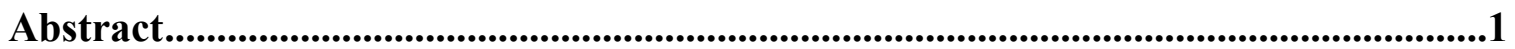

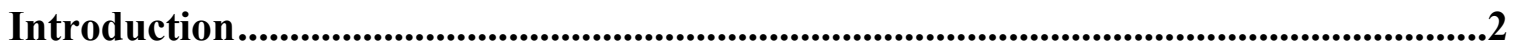

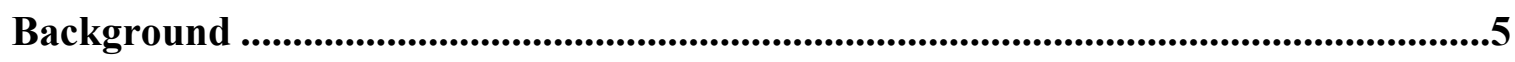

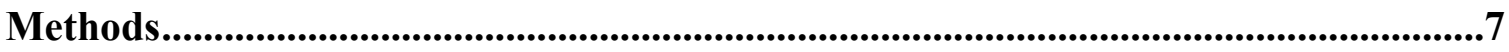

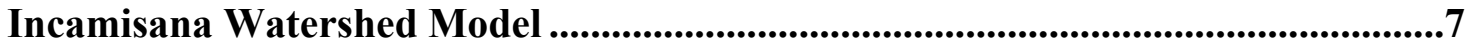

Mountain Canal System Model ...................................................................................13

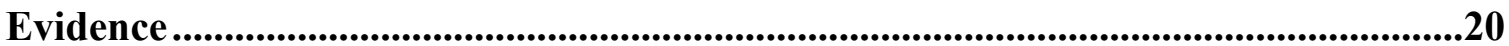

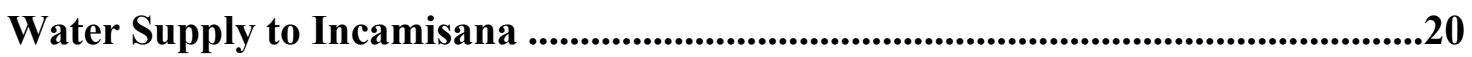

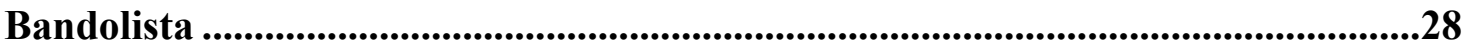

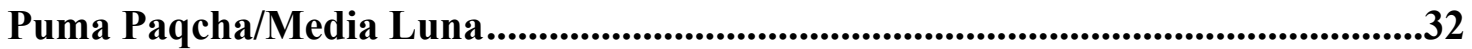

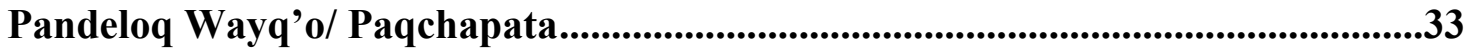

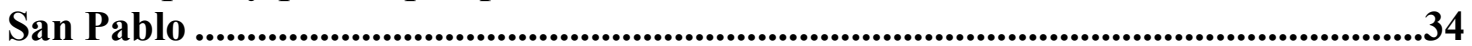

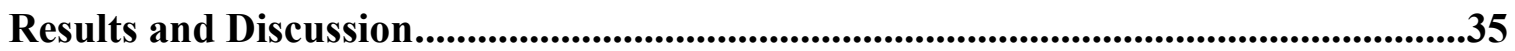

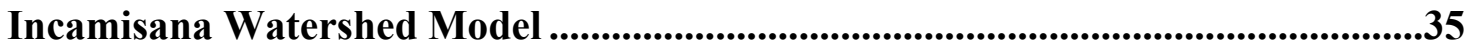

Mountain Canal System Model ..........................................................................44

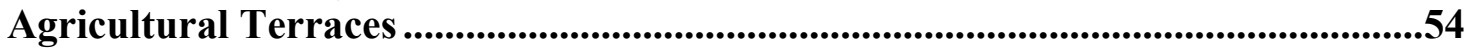

Conclusion

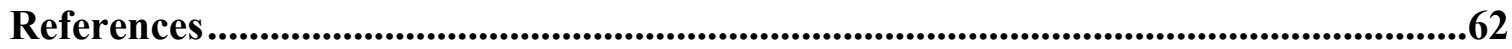

Appendix A: Step-by-Step ArcGIS Watershed Tutorial ..............................................64

Appendix B: Flow Rate Unit Conversions..........................................................................72

Appendix C: Full-Page Sized Maps............................................................................75 
List of Figures

Figure 1: Patachancha River Basin (National Institute of Civil Defense- Peru)..........3

Figure 2. General Site Overview. Site Layout Map Including Streams and Canals. 8

Figure 3. Incamisana Watershed. Sub-Basin Map with Basins Labeled. ....................9

Figure 4. Land Cover. Aerial Map Showing Landcover. ........................................12

Figure 5. Wetted Perimeter Diagram. Sketch of Typical Wetted Perimeter. .............14

Figure 6. Conjugate Depths Diagram. Illustrates the Concept of Conjugate Depths. Adapted from Civil Engineering Reference Manual for the PE Exam by $M$.

Lindeburg, 2003. Professional Publications.

Figure 7. Shield's Diagram for Sediment in Water. Illustrates Relationship Between Sediment Movement, Particle Reynolds Number, and Shield's Parameter. Adapted from The Hydraulics of Open Channel Flow by H. Chansen, 1999. John Wiley \& Sons.

Figure 8. Diagram of Fountains 5, 6, and 7. CAD Drawing Locating the Fountains With Respect to the Manyaraqui Canal. (Wright Paleohydrological Institute) ........21

Figure 9. Diagram of Fountains 5, 6, and 7, and the Manyaraqui Sector. CAD Drawing Locating the Fountains With Respect to the Manyaraqui Canal. (Wright Paleohydrological Institute)

Figure 10. Eight Terrace Complex. Photo of Eight Terrace Complex, Bifurcation Point, and the Incamisana. .23

Figure 11. The Bifurcation Point. Photo of the Bifurcation Feeding the Incamisana.

Figure 12. Notch Drop Structure. Photo of the Inca Drop Structure on Terrace Three.

Figure 13. Diagram of Fountains 1, 2, 3, and 4. CAD Drawing Locating the Fountains With Respect to the Bifurcation Point. (Wright Paleohydrological Institute)

Figure 14. Supply Canals to Incamisana. Map of the Three Water Supply Canals to the Incamisana.

Figure 15. Supply Canals to Incamisana. Photo of the Three Water Supply Canals as They Enter the Incamisana.

Figure 16. Unfinished Fountain 4. Photo of Fountains that were Unfinished. .28

Figure 17. Bandolista Canal Photo. Photo of the Bandolista Canal, the Existing Evidence is a Supporting Wall Along the Rock Face. 
Figure 18. End of Bandolista Canal to Top of Terrace Eight. Photo of the Last Point of Evidence of the Bandolista Canal to the Canal Above Terrace Eight. .30

Figure 19. Bandolista GPS Trek. Water Supply Map to the Incamisana Showing the GPS Points Taken During Fieldwork.

Figure 20. Media Luna Terraces with Pre-Inca Canal and Inca Twin Canal. Photo of the Media Luna Terraces with the Irrigation Canals Along Each Side. 32

Figure 21. Paqchapata/Chaqchapata Chute. Photo of the Paqchapata Chute. .33

Figure 22. Musk'a Pujiho Canal. Photo of The Musk'a Puijho Canal that is Still Flowing.

Figure 23. Canal Map. Map of the Canals Analyzed in Mountain Canal Model. ....35

Figure 24. Incamisana Watershed. Delineated Sub-Basin Map. ..............................36

Figure 25. Flow Direction Map. Flow Direction Raster Map.

Figure 26. Rainfall Data (Total and Days). Adapted from "Climate Sacred Valley/Urubamba" from http://www.zoover.co.uk/peru/peru/sacred-valleyurubamba/weather.

Figure 27. Canal Map. Map of the Canals Analyzed in Mountain Canal Model. ....45

Figure 28. Shield's Diagram for Sediment in Water Example. Illustrates

Relationship Between Sediment Movement, Particle Reynolds Number, and Shield's ParameterAdapted from The Hydraulics of Open Channel Flow by H. Chansen, 1999. John Wiley \& Sons. .54

Figure 29. Terrace Map. Map of the Terraces Investigated in the Study. .55 


\section{List of Tables}

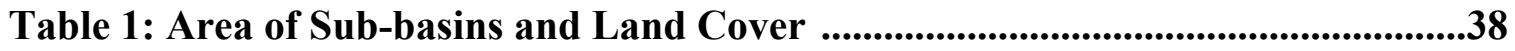

Table 2: Composite Curve Numbers ................................................................................39

Table 3: Lag Time and Time of Concentration ................................................................40

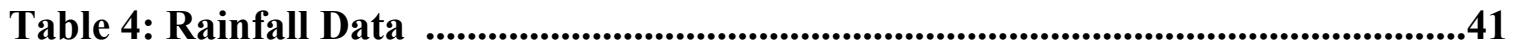

Table 5: Runoff Depth for Design Storm ..........................................................................43

Table 6: Volume of Runoff for Design Storm ....................................................................44

Table 7: Canal Specifications .............................................................................46

Table 8: Conjugate Depths ..............................................................................................47

Table 9: Canal Capacities in $\left(\mathrm{m}^{3} / \mathrm{s}\right) \quad$..........................................................................48

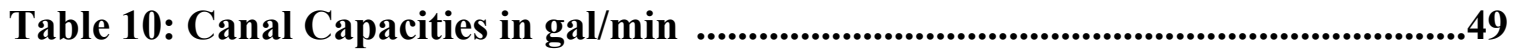

Table 11: Canal Velocities ...........................................................................................................50

Table 12: Canal Reynolds's Numbers .........................................................................51

Table 13: Canal Froude Numbers ....................................................................52

Table 14: Particle Reynolds Number, Shear Velocity, and Shield's Parameter........53

Table 15: Corn Crop Demand Data for Various Temperatures ...................................56

Table 16: Daily Rainfall and Daily Agricultural Demand .......................................57

Table 17: Area of Terraces by Sub-Basin ...................................................................57

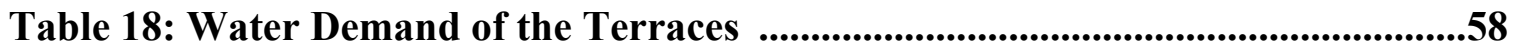

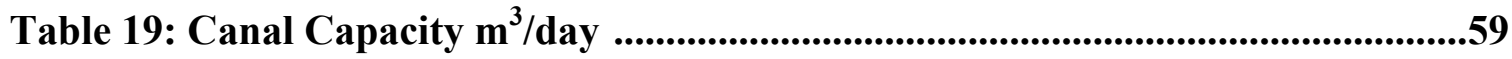




\begin{abstract}
The Incamisana, at Ollantaytambo Peru, is an ancient Inca water temple that exemplifies the high level of understanding the Inca engineers had for hydraulics and hydrology. The hydraulic engineering at this site extends up the mountainside in an extensive mountain canal system. The purpose of this study was to analyze the water supply to the Incamisana from a hydrologic point of view. The current sources for the Incamisana is the Rio Patacancha, and through field studies, a mountain stream has been identified as another potential source, via the Bandolista Canal, although the Inca may not have used it. There is no evidence that the Incamisana was fed by a spring source. There are consistencies in canal design; the canals typically have similar dimensions and 1.5 to $2 \%$ slope, which result in a subcritical flow, canals also had the ability to transport sediment. At $50 \%$ full, the canals had a capacity of about 5 million gal/day from the mountain streams, down to the valley where it was used. Fieldwork, flow calculations, and a watershed run-off analysis show that there is sustainable infrastructure and adequate water to supply the Incamisana, and also irrigate the agricultural terraces.
\end{abstract}




\section{Introduction}

The Incamisana is a ceremonial "water offering" built by the Inca for religious reasons. It is located in the Ollantaytambo complex in the Cusco Region of Peru. It is a water distribution network of canals, channels, and fountains. Ollantaytambo is in a valley of the Andes Mountains, alongside the Rio Patacancha. The city of

Ollanytaytambo is at an elevation of $2800 \mathrm{~m}(9186 \mathrm{ft})$, and is approximately $70 \mathrm{~km}$ (45 mi) from the city of Cusco, which served as the Inca Capitol during the Inca Empire. This site was developed in the $15^{\text {th }}$ Century as a royal estate for the Inca Ruler, Pachacuti. Ollantaytambo was an Inca city and ceremonial center for over 100 years. Multiple battles between the Inca and the Spaniards took place here, and it was used as a temporary capital during Manco Inca's reign as Inca ruler during the Spanish conquest (MacQuarrie, 2007). It is located in the mountainous Andes region in southern Peru, in an area called the "Sacred Valley of the Incas." The site includes extensive terraces and irrigation canals that have made it both a tourist attraction and archaeological site.

The Sacred Valley is also known as the Urubamba Valley, as the Urubamba River runs through the valley. The name of the Urubamba River is also called the Vilcanota River, and also the Wilcamayu River, depending on location. The exact location where the river changes its name is different depending on the source. On some maps, it is labeled as the Urubamba River at Ollantaytambo, but it is called the Vilcanota River at Ollantaytambo. The city is located where the Vilcanota River and the Patacancha River intersect. The valley that is investigated in this study is the Patacancha River Valley. This valley extends from Ollantaytambo and includes the towns Pumamarka, Pallata, Rucca, Yanamayo, and others. Ollantaytambo and the Patacancha River Basin are shown in Figure 1. 

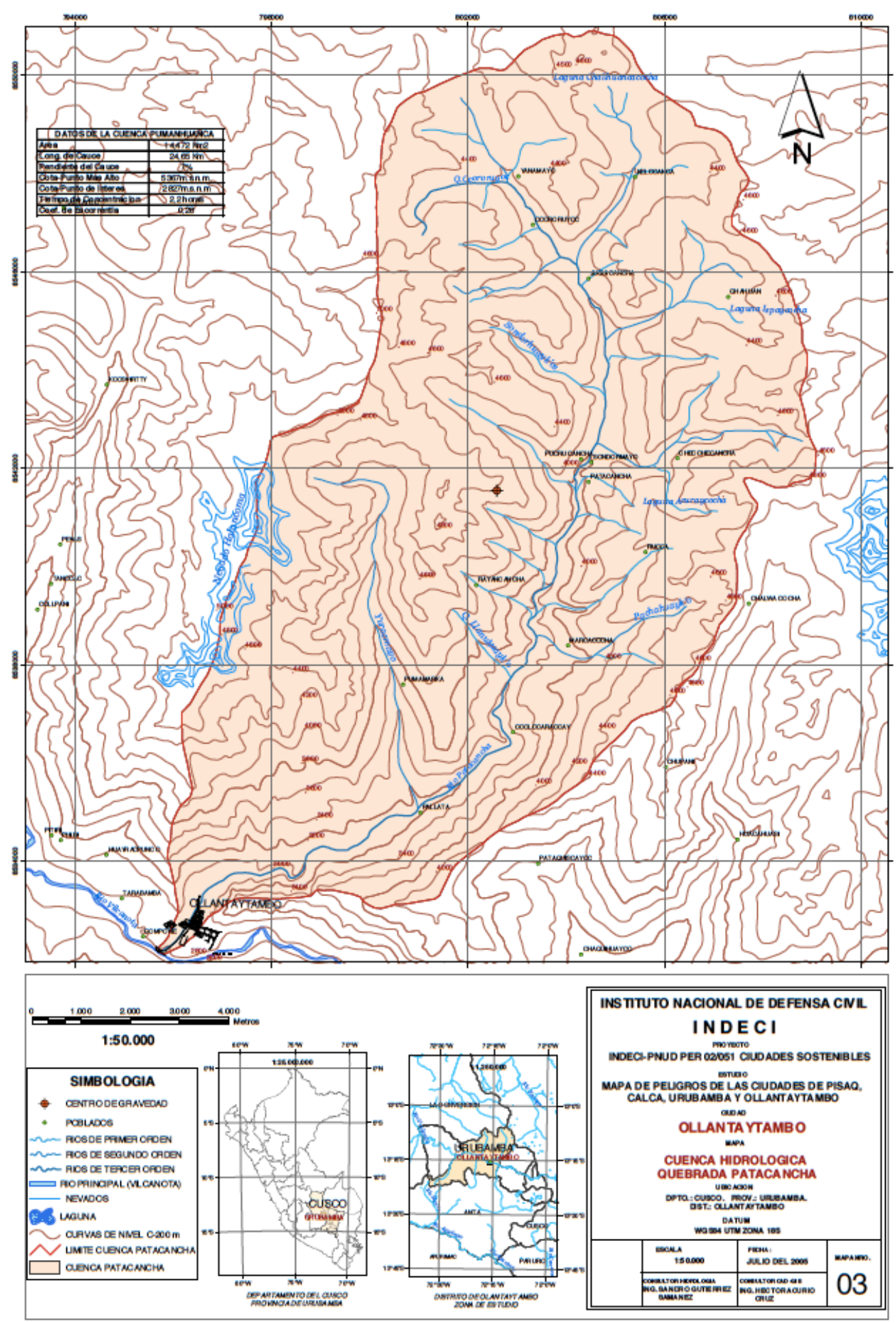

Figure 1: Patachancha River Basin (National Institute of Civil Defense- Peru)

Jean-Pierre Protzen has studied the Inca construction methods and history at Ollantaytambo in detail. In his book, titled Inca Architechture and Construction at Ollantaytambo, he provides a description of the buildings and temples. He focuses on the practicality of the design, the planning methods, and the design criteria that the Inca used 
to construct this site. Ann Kendall has studied many of the canals in this region, specifically the ones at Pumamarka and in the vicinity of the Rio Yuracmayo. She has studied the history and functionality of Inca canals, and works to restore them for use by the local people that currently reside in these areas.

Through field study at Ollantaytambo, three canals were identified as possible sources for the Incamisana. These canals are a part of the extensive mountain canal system that provided for the domestic and agricultural needs of the Inca city. The Incamisana Watershed is a water-rich valley along the Rio Patacancha, from the Incamisana, up to the Rio Yuracmayo. These canals effectively brought water from the tributaries downvalley to where it was needed. The canal infrastructure was adequate to meet the water demand of the valley. The canals of particular interest for this study are the ones that were able to feed the Incamisana water temple complex. Lake Yanacucha and a highelevation canal that likely fed the Incawitana are outside the scope of this project and are not discussed in this report. This study aims to uncover Peruvian and Inca history, specifically engineering and design practices, based on field evidence and engineering analysis. It also provides engineering insight to archaeologists that plan to do later excavations.

There is rich Inca history in Ollantaytambo, and some unsolved mysteries. There was an extensive flood in the area in the late 1600s, and the Incamisana was buried under the flood sediments until Dr. Arminda Gibaja Oviedo, the Chief Archaeologist, from the National Institute of Culture at Cuzco, or INC, excavated the area in 1980-1982, and rediscovered the Incamisana. She is the archaeological authority on the canals in the mountain canal system in the Incamisana Watershed, and she accompanied the research team during the fieldwork explorations at Ollantaytambo for this project.

The Inca were skilled hydrologists. They were masters of low-impact sustainable environmental design. This is consistent with all Inca sites. They built agricultural terraces into the Andes Mountains, extravagant complexes for their rulers, and extensive water distribution networks. Their understanding of structural mechanics, fluid mechanics, and hydrology continues to impress today's civil engineers. The Inca did not use iron or steel. They did not use the wheel, and they also had no written language. There were no engineering design manuals, but they were able to build infrastructure for their empire that still stands today, over 500 years later.

The Inca Empire lasted from the mid 1400s until 1533, when the Spanish Conquest began. The Inca Empire was the largest in pre-Columbian America (D'Altroy, 2002). Although the Spaniards began destroying Inca structures in the 1530s, and urbanization and development has been negatively affecting them ever since, many original Inca structures are still standing (Niles, 1987). This sparks an interest for architects, engineers, and archeologists.

Irrigation methods and Inca use of water are the most relevant aspects of Inca culture to the research at Ollantaytambo discussed in this thesis. Canals typically run from rivers down to the agricultural sector of the towns. Different tiers of channels were "drawn from the stream at different heights, often in pairs that are carried along the side wall of a canon toward the main valley" (Niles, 1987). This was useful because by 
drawing off water as much as possible, engineers could water many terraces at different elevations.

The Inca were aware of how impressive and valuable their systems of canals and channels were, and used them as a symbol of their power (Niles, 1987). When the Inca conquered new lands, they implemented their irrigation networks, not only to increase production, but also to impress the native people. Canals served as reminders of the "Inca presence and their domain of the social world and the world of nature in much the same way that roads and administrative centers must have functioned" (Niles, 1987).

The Inca typically used spring water for religious ceremonies and for domestic water use.

In the flood at Ollantaytambo, evidence was lost. Some canals, especially ones closest to the Incamisana have been destroyed and reconstructed. The Incamisana water complex is a ceremonial religious water offering; historical patterns suggest that the Inca used pure, spring water for ceremonial purposes. That being said, the current feed to the Incamisana is from the Rio Patacancha via the Huaca Canal. In this paper, there is no speculation as to what is original Inca and what is modern, but it identifies the field evidence and makes engineering conclusions.

In this study, the canals in the Incamisana Watershed are analyzed from a hydrologic point of view, and the possible water sources to the Incamisana are identified. Irrigation canals are also identified. The natural hydrology of the Peruvian watershed is analyzed, and this study may be used as a template for similar studies at different sites. Stormwater runoff peak flow rates are calculated for this watershed, as well as canal capacities, flow rates, and water demand of the crops grown on the agricultural terraces. The stormwater runoff calculations help to analyze the natural hydrology of the basins. The canal capacity calculations and the water demand of the crops show how much water was used.

\section{Background}

Paleohydrology is the study of the handling and use of water by ancient civilizations. Kenneth Wright, who founded the Wright Paleohydological Institute, and Richard Miksad from the Civil and Environmental Engineering Department at the University of Virginia have conducted several studies at different Inca sites in Peru, namely Machu Pichhu, Tipon, Moray, and Saqsaywaman. Each of the projects was unique, but basic engineering principals were used to model the hydrology and the hydraulics at each site.

Each Inca site had its own problem or mystery that needed to be solved, and with some engineering intuition and archaeological insight, it is possible to develop these theories beyond speculation. Wright's studies at Machu Picchu, Tipon and Moray differ from the study at Saqsaywaman. At Machu Picchu, the question was how the Inca delivered water to the city, which was located on the top of the mountain. In that study, engineers set out to determine if there was a suitable water supply and conduct water supply evaluations. The Machu Picchu study exposed a perennial spring to the north of Machu Picchu. The spring could supply water to the urban sector, carried by gravity, as long as the slope of the canal was carefully controlled. The canal brought water into the 
set of fountains that served as the domestic water supply. The Inca found and developed the spring, whose sources were rainfall and a tributary drainage basin. The drainage basins were determined by means of site observations and photographic interpretation. Machu Picchu Spring is a natural phenomenon; its reliable yield, which fluctuates between $23 \mathrm{~L} / \mathrm{min}$ and $125 \mathrm{~L} / \mathrm{min}$, is aided by a stone spring collection that still functions today (Wright and Megara, 2000).

At Moray, historically renown an agricultural center, research found that the water supply and infrastructure could not support agriculture (Wright et al., 2011). Its circular terraces, called muyus, characterize the site; the temperature change from the top to the bottom terrace is sometimes $15^{\circ} \mathrm{C}$, or $27^{\circ} \mathrm{F}$. For this reason, many have believed that it was an agricultural research center, where they could grow different crops at different climatic conditions. Site inspection, field research, and flow calculations provided contradictory evidence, showing that there was not proper irrigation infrastructure to support agriculture. The Inca planners developed a spring that could be tapped when needed, and moved downhill to the canals along the terraces. The Inca had problems stabilizing the land, and did not irrigate the terraces because irrigation would have added to the stability problems. The Moray study is an example of how a historical theory can be disproven with engineering evidence.

At Tipon, Wright and others modeled the hydraulics and hydrology of the site. This site is a great example of how Incas integrated function and aesthetics. The land at Tipon has been irrigated and farmed for over 450 years. Tipon is also a great example of how the Inca planners understood water supply so that is was always balanced and well managed (Wright, 2006). The spring and water supply aqueduct was identified and there was evidence that this site was carefully conceptualized, planned, designed, and built.

The Saqsaywaman study was slightly different; this was a project lead by Dr. Richard Miksad. The walls and terraces at Saqsaywaman, Cusco, Peru stood for over 500 years. Recently, some of the walls have collapsed due to structural instability. This study focuses on the increased rainfall runoff because of post-Inca changes in land use. The study includes a hydrologic rainfall-runoff analysis and identifies the impact of the changes in historic drainage basins. Soil types and land use data were taken during field observation, and drainage capacity of each basin was determined by the Rational Method and estimated historical rainfall intensity. It was found that at this site, the new impervious surfaces increased the rate, volume, and frequency of runoff in many of the basins. The rates and volumes have increased over 100\% since the Inca era, and drainage canals have been damaged (Wildfire et al., 2011). The project team recommended a master drainage study on the site, and a remedial action must be taken to address the hydrologic and hydraulic problems in the area.

These studies all exemplify the importance of paleohydrology, whether the goal is to uncover history, or to help to preserve the beauty of the Inca structures. The present study at Ollantaytambo uses many of the same methods that were used at other sites, but in the context of a different geographic location. It is amazing to witness first-hand the intellect and engineering intuition the Inca had. They were incredibly intelligent people 
with a deep connection to their environment that is admirable by today's engineers, archaeologists, and tourists alike.

\section{Methods}

There are two parts of this study, the watershed model, and the canal system model. They are integrated, but different methods were used for each. The watershed analysis was a combination of GIS and Natural Resources Conservation Services (NRCS) runoff analysis, using field observations to make appropriate assumptions. The canal investigation was a combination of field studies over two one-week intervals, one over the summer of 2011, and one in the summer of 2012. The field studies along with standard engineering flow calculations lead to conclusions about the possible sources of water for the Incamisana.

\section{Incamisana Watershed Model}

The GIS watershed analysis, which is thoroughly outlined in Appendix A, begins with defining the area of interest. The area defined is called the Incamisana Watershed, and, as shown in Figure 2 it includes the Incamisana, and the area to the northeast, up to the Rio Yuracmayo, along the Rio Patacancha. To explain the watershed characteristics, the site is described from the Incamisana, up-valley to the Rio Yuracmayo. As shown in Figure 3, the Incamisana Watershed consists of five main sub-basins from the Incamisana upstream: Bandolista, Puma Paqcha/Media Luna, Pandelayoq Wayq'o/ Paqchapata (or Chaqchapata), San Pablo, and Yuracmayo. Two of the sub-basins have multiple names, and both names are Quechuan and also used locally. Paqchapata and Chaqchapata are the local names for the same stream, one is for when the water level is high, and the other is for when water levels are low, respectively. Another note is that at the top of the Pandelayoq Wayq'o Stream, there is a "field of springs," called the Pandelayoq Wayq'o Field of Springs. At the bottom of this stream, is the Paqchapata Chute; the chute has a steep slope, high flow rate, and supercritical flow. 


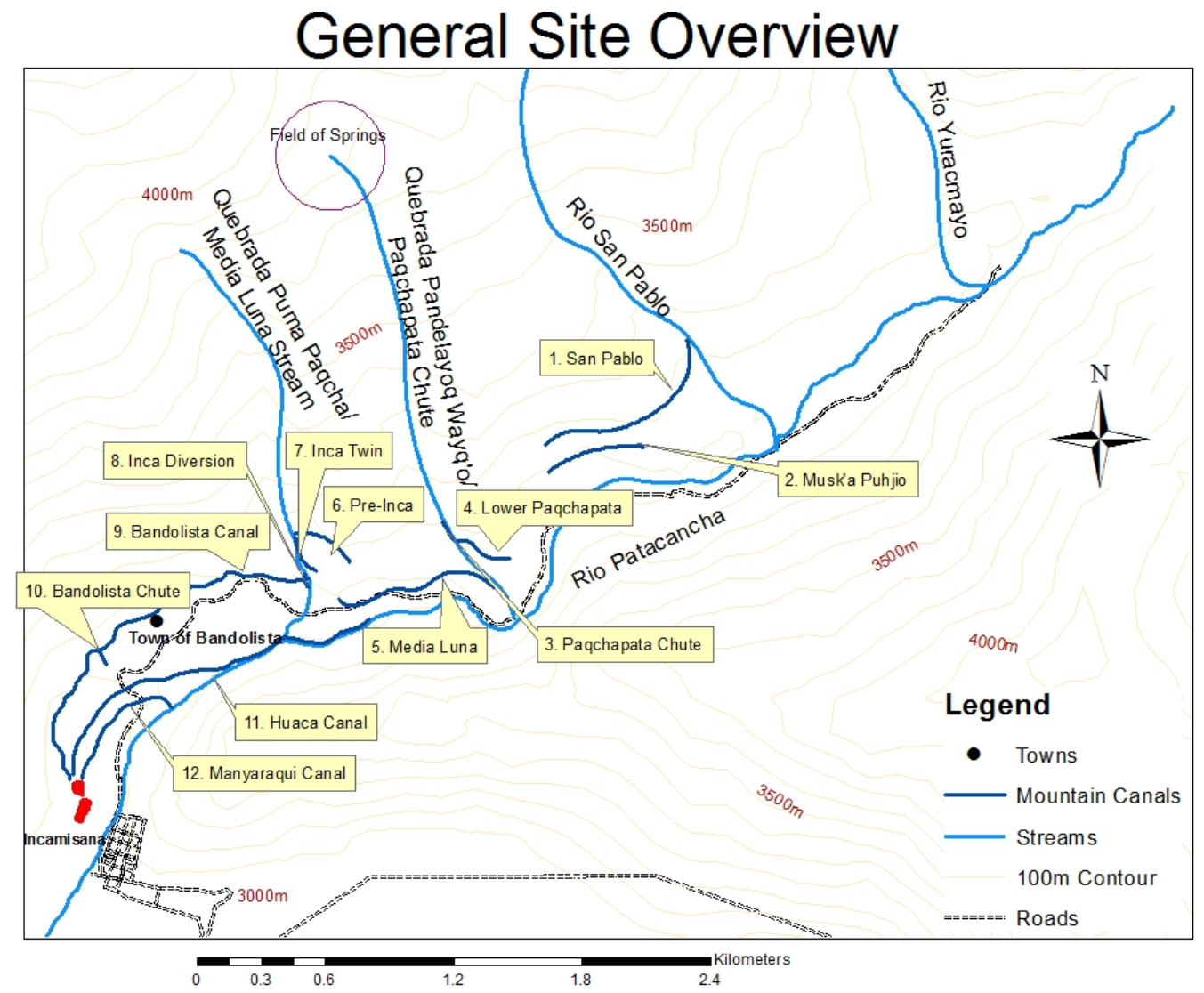

Figure 2. General Site Overview. Site Layout Map Including Streams and Canals. 


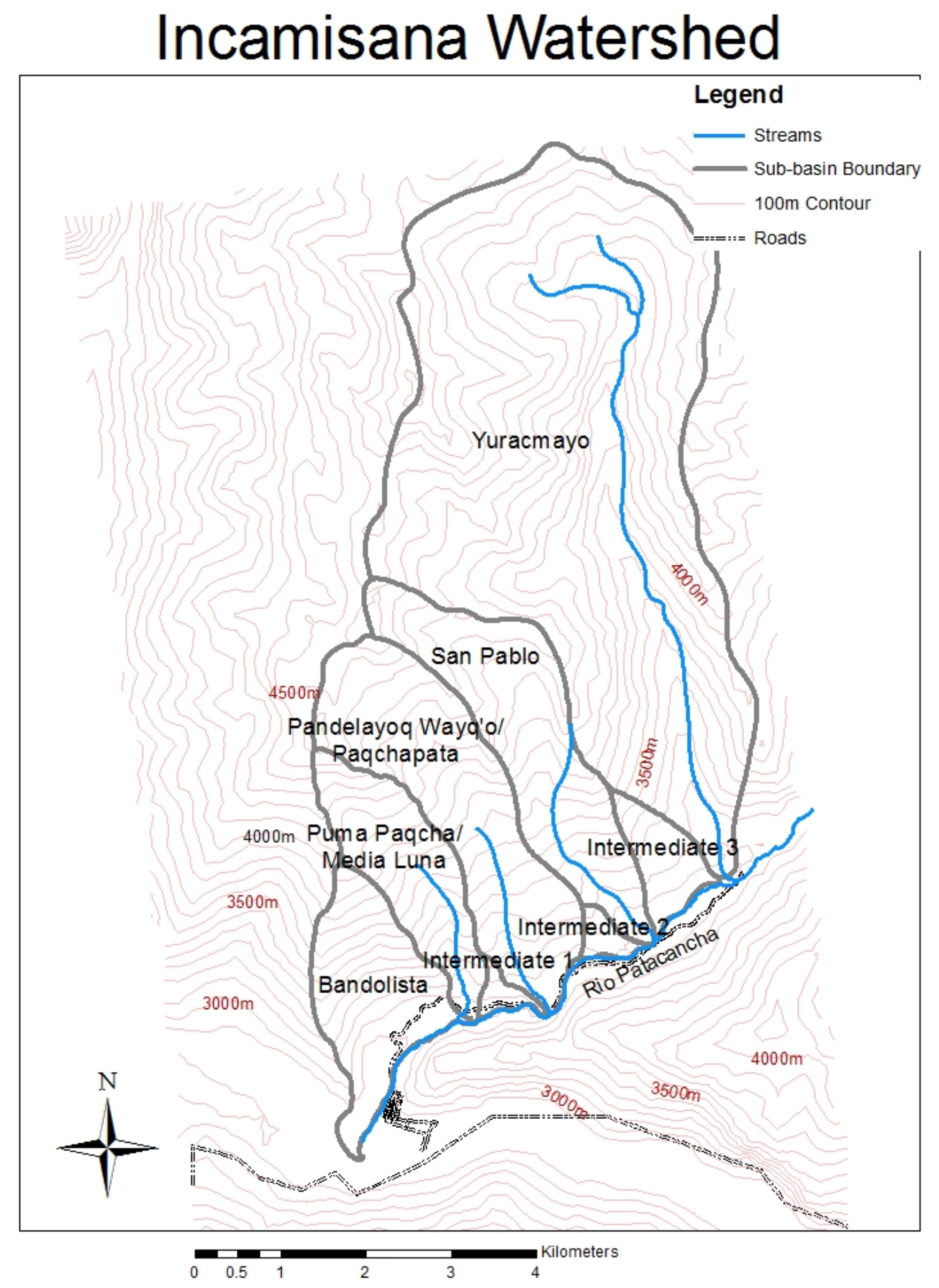

Figure 3. Incamisana Watershed. Sub-Basin Map with Basins Labeled. 
The Incamisana Watershed is defined by these sub-basins that are along the northeast side of the Patacancha Valley, the same side of the Rio Patacancha as the Incamisana. The south side was not studied because it is not directly relevant to the Incamisana. There are small sections of land that lie in between the main sub-basins that are not technically included in the large watersheds. These small plots of land are numbered, Intermediate 1, 2 , and 3, and calculations are used as a check, to make sure the analysis makes sense. For example, there is minimal runoff on these areas. Average monthly rainfall data is used to find monthly runoff rates. The results show that much of the water is infiltrated, and the runoff is minimal, especially in Bandolista, where there is not enough runoff to create a stream within the sub-basin. With the exception of Bandolista, all the sub-basins contain a mountain stream that is a tributary to the Rio Patacancha. The sub-basin names correlate with the stream within it.

A digital elevation model, or DEM, was used to create a topographic model of the Incamisana Watershed. The DEM is from the Advanced Spaceborne Thermal Emission and Reflection Radiometer, or ASTER, data set. ASTER data is $30 \mathrm{~m}$ by $30 \mathrm{~m}$ resolution elevation data. This data is also used to determine flow directions for runoff, and locate the streams or tributaries based on the flow accumulation. The DEM is also used to delineate the boundaries of each sub-basin based on the topography and location of the streams, and the program calculates the area of each sub-basin once they were defined.

The NRCS Curve Number Runoff method is used to determine runoff rates. This method is used to estimate runoff from storm rainfall, and is commonly used in engineering practice (USDA 1986). This method uses the runoff curve number $(C N)$, which depends on the soil and cover conditions, which the model represents as hydrologic soil group, land cover, and hydrologic condition (USDA, 1986). The runoff equation is:

$$
Q=\frac{\left(P-I_{a}\right)^{2}}{\left(P-I_{a}\right)+S}
$$

Where

$Q=$ Runoff (in or $\mathrm{mm}$ )

$P=$ Rainfall (in or $\mathrm{mm}$ )

$S=$ Surface storage before the onset of runoff (in or $\mathrm{mm}$ )

$I_{a}=$ Initial abstraction (in or $\mathrm{mm}$ )

The initial abstraction is all losses before the runoff starts, which includes water that is infiltrated, evaporated, intercepted by vegetation, and water that collects in surface depressions. It is approximated with an empirical equation:

$$
I_{a}=0.2 S
$$

Substituting Equation 2 into Equation 1 gives the following equation:

$$
Q=\frac{(P-0.2 S)^{2}}{(P+0.8 S)}
$$

Equation 3 is only valid when $P$ is greater than $0.2 S$ (USDA, 1986).

$S$ is surface storage before the onset of runoff, is related to the soil cover and land cover through the $C N$ by the following equation: 


$$
S=\frac{25400}{C N}-254
$$

Equation 4 is valid when $S$ is in $\mathrm{mm}$; the constants are different when the units are in inches. The Curve Number is a number between 0 and 100, based on the permeability of the soil type. Soil type $\mathrm{C}$ is used for the Incamisana Watershed, which is sandy clay loam; this assumption was based on field observation. The land cover is mostly shrub/scrub in steep slopes; the $C N$ for this type of land cover is 70 (USDA, 1986). It is assumed that $10 \%$ of each watershed is covered with trees, with a $C N$ of 76 , which was observed in the field. Today most of the trees are "eucalyptus globulus," commonly called eucalyptus trees. These trees are not native plants; they are from Australia and have been placed in the Andes Mountains as a result of reforestation efforts (Luzar, 2007). Deforestation has been taking place in Peru before, during, and after the Inca Empire. Researchers have found hundreds of "Prosopis pallida," commonly called huarango, stumps in the Lima area, and confirmed that trees had been cut down (Coghlan, 2009). It is assumed that if eucalyptus trees are there now, the huarango trees were likely there 500 years ago. The terraces are assigned a $C N$ of 79 . The land cover can be verified with Figure 4 below. These values for $C N$ are used to calculate the composite $C N$, sum each $C N$ value multiplied by its ratio of the total sub-basin area. The sum is then rounded to the nearest whole number; the rounded result is used for all other calculations (Wurbs and James, 2002). A composite $C N$ is calculated for each sub-basin, along with a corresponding surface storage, $S$, initial abstraction, $I_{a}$, and runoff, $Q$.

The value for $\mathrm{P}$, rainfall, which is used in this analysis, is an estimate of an extreme weather event in Ollantaytambo based on weather patterns in Cusco, and rain data from Urubamba. The closest rain gauge that was available to acquire data from was in Urubamba, which is at the same altitude as Ollantaytambo.

The NRCS Curve number runoff method an appropriate analysis for this project. It was especially easy to implement because of the lack of available data. The only parameters needed are the amount of precipitation and the Curve Number. Although the equation does not incorporate time, in practice, daily precipitation rates are generally used. This method is typically used in practice to calculate the runoff from agricultural basins. There are some limitations to the method, as time is not taken into account. If the rainfall were intermittent, there would be some recovery of infiltration rates during the time of no rain. The rainfall intensity is also not taken into account; for example, a quick downpour could result in more runoff than a drizzle over a longer period of time. The method is not used to calculate exact conditions for a specific storm, but more to make an estimate in an area where soils, vegetation, and other characteristics affecting runoff have not been evaluated experimentally (Woodward, 1998). Engineers and hydrologists interested in downstream impacts of different land cover and management alternatives typically use the method for design purposes. 


\section{Land Cover}

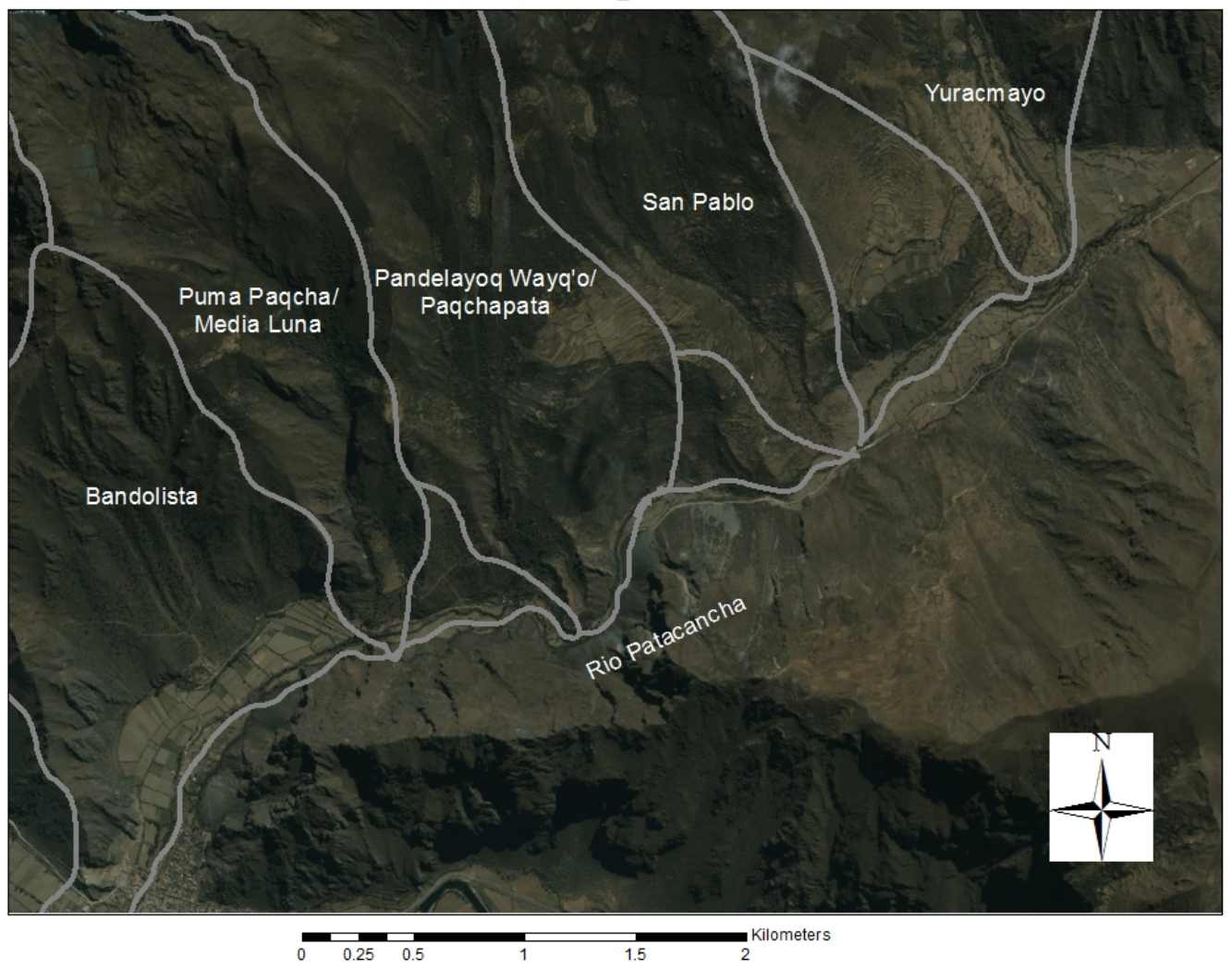

Figure 4. Land Cover. Aerial Map Showing Land cover. (Bing Maps)

The Length Tool within ArcGIS was used to measure the hydraulic lengths. The hydraulic length of a sub-basin is the length of the longest flow path within the sub-basin; in this case that is the flow path from the most distant point in the sub-basin to the Rio Patacancha. The hydraulic lengths are then be used to calculate the time of concentration, which is the time it takes for a water particle to travel along the entire hydraulic length. The time of concentration is calculated using the NRCS Equation for time to peak, which is:

$$
t_{L}=0.6 t_{C}
$$

And

$$
t_{L}=\frac{L^{0.8}(2540-22.86 C N)^{0.7}}{1410 C N^{0.7} Y^{0.5}}
$$

Where

$$
\begin{aligned}
& t_{L}=\text { Lag time (hours) } \\
& t_{C}=\text { Time of concentration (hours) }
\end{aligned}
$$


$L=$ hydraulic length (m)

$C N=$ Curve Number (dimensionless)

$Y$ is slope (\%)

Lag time is the time of delay between the time runoff begins until runoff reaches its maximum peak (Wurbs and James, 2002). The slopes are found by taking the elevation difference between the two ends of the overland flow path and dividing by the overland flow length.

There is a small area of terraces in each watershed. The area of the terraces play a very small role as far as the amount of runoff, because the area of terraces is so small compared to the size of the sub-basins, but these areas are important in calculating the agricultural water demand. The agricultural terraces are signature features of Inca landscaping. Their agricultural tactics allowed them to maximize the production of food to provide for a large number of people for export. The Inca did not have money, wheels, or work animals, but their terracing and irrigation methods allowed them to produce enough food for at least 15 million people (National Research Council Staff, 1989). The Inca's productivity and organizational skills even allowed them to store 3-7 years' supply of food. The Inca grew a variety of roots, grains, legumes, vegetables, fruits, and nuts (National Research Council Staff, 1989). For the sake of calculations, it is assumed that the agricultural terraces of Ollantaytambo were used to grow corn, as corn was the most abundant crop in this region (National Research Council Staff, 1989). Gross evapotranspiration rates are used to estimate water demand. The depth of water needed for corn to grow changes depending on the temperature and stage of growth. Depths of evapotraspiration per day along with the area of terraces for each sub-basin are used to determine a water demand per day in each basin in each of these circumstances.

\section{Mountain Canal System Model}

The report "The Pre-Hispanic Hydraulic System of the Ollantaytambo Archaeological Park Inkamisana and Manyaraqui Sectors," by Dr. Arminda Gibaja Oviedo, of the INC, and the accompanied maps, lay out her archaeological hypothesis of the locations of each canal. After the Summer 2011 trip, the field study resulted in a map that did not agree completely with the maps that accompany this paper. Using these differences as a starting point for the Summer 2012 trip, Dr. Gibaja Oviedo was asked to show the canals that had undocumented evidence. The mountain research team consisted of two engineers from Wright Water Engineering, two engineers from the University of Virginia, Dr. Arminda Gibaja Oviedo, and her colleague Emilio Alvarez, INC Assistant. After hiking for four days, the majority of Dr. Gibaja Oviedo's map was verified. At least three days were spent looking at where a pre-Inca canal ran from the town of Bandolista to the Incamisana, this Killke canal is referred to as the Bandolista canal. The Paqchapata Chute feeds the Media Luna Canal but there is no evidence that this canal feeds the Incamisana. This is an important finding, because the Field of Springs is the only spring source that feeds a canal that could conceivably be a source to the Incamisana. This suggests that the ancient source of the Incamisana was not a pure spring source. 
As evidence of canals was found, waypoints were taken on GPS units so that the location could be mapped. The field evidence observed was different for each canal, in some cases there is an existing canal, sometimes there are obvious cross-sections, and in other cases there is only a supporting wall. Depth, width, and slope measurements were taken at points where distinct canal sections could be identified. A two-foot level and a tape measure were used to get the measurements. The canal dimensions were averaged along its length for each canal, and used to calculate flow rate capacities for each canal. For each canal, the cross sectional areas that were recorded in the are within $1-5 \%$ of each other, so using average measurements for each canal was reasonable.

The dimensions recorded in the field were used to calculate a hydraulic radius, $R$, is a measure of efficiency of a channel. The larger the hydraulic radius, the more efficient the channel is, or more volume it can move. It is defined as:

$$
R_{H}=\frac{A}{P}
$$

Where

$$
\begin{aligned}
& R_{H}=\text { Hydraulic radius }(\mathrm{m} \text { or } \mathrm{ft}) \\
& A=\text { Cross-sectional area of the channel }\left(\mathrm{m}^{2} \text { or } \mathrm{ft}^{2}\right) \\
& P=\text { Wetted perimeter }(\mathrm{m} \text { or } \mathrm{ft})
\end{aligned}
$$

The wetted perimeter is the perimeter of the cross-sectional area that is wet, as seen in Figure 5.

\section{Rectangular Channel Cross Section}

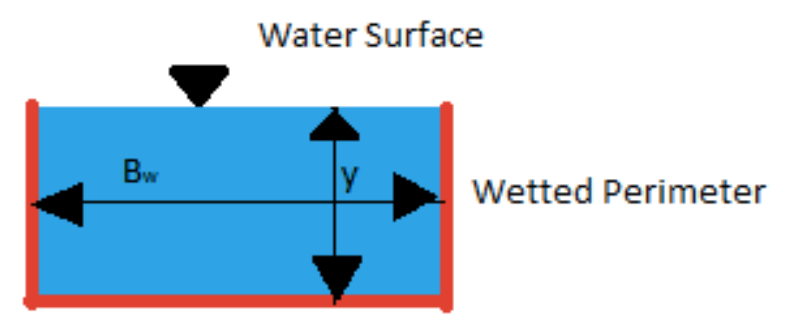

1

Figure 5. Wetted Perimeter Diagram. Sketch of Typical Wetted Perimeter.

For the rectangular channels use the following equation is used for hydraulic radius:

$$
R_{H}=\frac{B_{w} y}{B_{w}+2 y}
$$

Where 


$$
\begin{aligned}
& R_{H}=\text { Hydraulic radius }(\mathrm{m} \text { or } \mathrm{ft}) \\
& B_{w}=\text { Width of the channel }(\mathrm{m} \text { or } \mathrm{ft}) \\
& y=\text { Depth of flow }(\mathrm{m} \text { or } \mathrm{ft})
\end{aligned}
$$

This hydraulic radius is then used to calculate the volumetric flow rate of the canals. The flow rates are calculated with Manning's Equation:

$$
Q=\frac{1}{n} A R_{H}^{3 / 2} S_{0}^{1 / 2}
$$

Where

$$
\begin{aligned}
& Q=\text { Volumetric flow rate }\left(\mathrm{m}^{3} / \mathrm{s}\right) \\
& n=\text { Manning coefficient } \\
& A=\text { Cross-sectional area of the channel }\left(\mathrm{m}^{2} \text { or } \mathrm{ft}^{2}\right) \\
& \left.R_{H}=\text { Hydraulic radius (m or } \mathrm{ft}\right) \\
& S_{0}=\text { Slope of channel }(\mathrm{m} / \mathrm{m} \text { or } \mathrm{ft} / \mathrm{ft})
\end{aligned}
$$

The Manning coefficient, $n$, is a constant that is determined by the material of the channel. Values of $n$ used were 0.035 for winding (not straight) channels constructed with smooth uniform stones, and 0.04 for winding channels constructed with of jagged and irregular stones (Mays, 2010). Most of the canals were made of smooth and uniform stones, with the exception of the agricultural canals Musk'a Pujiho, San Pablo, and Lower Paqchapata, which were constructed with jagged and irregular stones. All other canals were assumed to be composed of smooth and uniform stones.

The water supply for the canals, with an exception of the Huaca Canal, is the mountain streams. The Huaca Canal is named this because as the canal enters the Eight Terrace Complex, it passes a Huaca, which is a very large stone with religious or symbolic significance to the Inca. The seasonal variability of the streams is unknown, but it is assumed that there is more flow in the summer and less in the winter. For this reason, a sensitivity analysis was done, and the capacities were calculated at $100 \%$ full, $80 \%$ full, $50 \%$ full, and $30 \%$ full. That is, using the entire depth of the channel, 0.8 of the depth of the channel, 0.5 of the depth of the channel, and 0.3 of the depth of the channel, as the value of $y$ for all calculations.

Then, the velocity of the water can be calculated using the relationship:

$$
V=\frac{Q}{A}
$$

Where

$V=\operatorname{Velocity}(\mathrm{m} / \mathrm{s})$ 
$Q=$ Volumetric flow rate $\left(\mathrm{m}^{3} / \mathrm{s}\right)$

$A=$ Cross-sectional area $\left(\mathrm{m}^{2}\right)$

The velocity is used to compute Reynolds Numbers. The key assumption for using the Manning's Equation is that there is rough turbulent flow. This means that the inertia forces are greater than viscous forces. Turbulent flows produce vortices and other flow instabilities. This is calculated by using Reynolds number. Reynolds number, $R e$ is the dimensionless ratio of gravity forces to inertia forces. At Reynolds number higher than 2000, flows are considered turbulent (Mays, 2010). The Reynolds number is computed with the following equation:

$$
\operatorname{Re}=\frac{V R_{H}}{v}
$$

Where

$$
\begin{aligned}
& R e=\text { Reynolds number (dimensionless) } \\
& V=\text { Channel velocity }(\mathrm{m} / \mathrm{s} \text { or } \mathrm{ft} / \mathrm{s}) \\
& R_{H}=\text { Hydraulic radius of the channel }(\mathrm{m} \text { or } \mathrm{ft}) \\
& v=\text { Kinematic viscosity in }\left(\mathrm{m}^{2} / \mathrm{s} \text { or } \mathrm{ft}^{2} / \mathrm{s}\right)
\end{aligned}
$$

The kinematic viscosity is assumed to be $1\left(10^{-6}\right) \mathrm{m}^{2} / \mathrm{s}$.

Another important characteristic of uniform channels is whether they have subcritical or supercritical flows. A general rule of thumb is that supercritical flows are shallow and fast, while subcritical flows are deep and slow tranquil flows. This is calculated with the Froude number, which is the ratio of gravity to inertia.

$$
F r=\frac{V}{\sqrt{y g}}
$$

Where

$$
\begin{aligned}
& F r=\text { Froude number } \\
& V=\text { Velocity of uniform channel }(\mathrm{m} / \mathrm{s} \text { or } \mathrm{ft} / \mathrm{s}) \\
& y=\text { Depth of uniform channel }(\mathrm{m} \text { or } \mathrm{ft}) \\
& g=\text { Acceleration due to gravity }\left(9.81 \mathrm{~m} / \mathrm{s}^{2} \text { or } 32.2 \mathrm{ft} / \mathrm{s}^{2}\right)
\end{aligned}
$$

A Froude number less than one represents subcritical flow, while a Froude number greater than one indicates supercritical flow. This concept is noteworthy because the majority of Inca canals have subcritical flows. If the canals carried supercritical flows for long periods of time, then the canals would have eroded long ago, which means the Inca understood this concept. This is important for the chutes and steep canals because using just Equation 9, Manning's Equation, to calculate the flow rates for the San Pablo 
Canal, Paqchapata Chute, Inca Diversion, Bandolista Chute, and the Manyaraqui Canal, results in extremely high and unrealistic velocities. This was used for these canals because they have Froude Numbers larger than 1 when calculated using Equation 9 with these steep slopes.

The Inca used hydraulic jumps to dissipate the energy of the flow, and "slows down" the flow. A hydraulic jump is a rise in the water surface from a supercritical depth to a subcritical depth, or a water depth that results in a supercritical or subcritical flow, respectively. The depths on each side of the hydraulic jump are conjugate depths (Lindeburg, 2003). Equation 13 below was used to calculate the conjugate depth:

$$
d_{2}=-\frac{1}{2} d_{1}+\sqrt{\frac{2 V_{1}^{2} d_{1}}{g}+\frac{d_{1}^{2}}{4}}
$$

Where

$$
\begin{aligned}
& d_{l}=\text { Upstream supercritical depth }(\mathrm{m}) \\
& V_{l}=\text { Velocity calculated with Manning's Equation }(\mathrm{m} / \mathrm{s}) \\
& d_{2}=\text { Downstream subcritical depth }(\mathrm{m}) \\
& g=\text { Acceleration due to gravity }\left(\mathrm{m}^{2} / \mathrm{s}\right)
\end{aligned}
$$

These variables are illustrated in Figure 6, below.

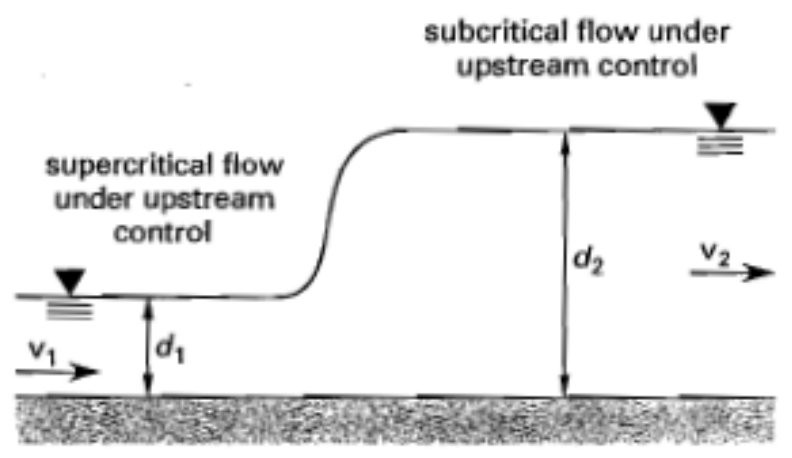

Figure 6. Conjugate Depths Diagram. Illustrates the Concept of Conjugate Depths. Adapted from Civil Engineering Reference Manual for the PE Exam by M. Lindeburg, 2003. Professional Publications.

Equation 13 was used with a trial and error method to find the maximum value of the upstream supercritical depth, $\mathrm{d}_{1}$, which results in a downstream subcritical depth, $\mathrm{d}_{2}$, which is less than the measured channel depth. If the conjugate depth were greater than the channel depth, the channel could not contain the flow. These maximum values for the upstream supercritical depth were the depths used to calculate the maximum velocities and flow rates. 
It is apparent by observation of the Inca canals that are still functioning, that the Inca designed and built their canals with the ability to transport sediment. This means that the velocity of the water and the sediment particles is fast enough to prevent substantial build-up of sediment within the canals. This can be shown by calculating a Shield's Parameter, $\tau_{*}$, which is a function of the particle Reynolds number, and the shear velocity. The particle Reynolds number is similar to the Reynolds number that was previously calculated, but it is the ratio of the viscous forces to the gravity forces of the particle of sediment. Shear velocity is sometimes referred to as friction velocity, and is not truly a velocity, but it is the frictional forces due to the walls of the channel expressed in dimensions of velocity (Hubert, 1999). The equations used to calculate these parameters are Equations 14, 15, and 16, presented below.

$$
\operatorname{Re}_{*}=\frac{V_{*} d_{s}}{v}
$$

Where

$$
\begin{aligned}
& R e_{*}=\text { Particle Reynolds Number } \\
& V_{*}=\text { Shear Velocity }(\mathrm{m} / \mathrm{s}) \\
& d_{s}=\text { Average particle size }(\mathrm{m}) \\
& v=\text { Kinematic viscosity in }\left(\mathrm{m}^{2} / \mathrm{s} \text { or } \mathrm{ft}^{2} / \mathrm{s}\right)
\end{aligned}
$$

The kinematic viscosity is assumed to be $1\left(10^{-6}\right) \mathrm{m}^{2} / \mathrm{s}$. The average particle size is the size of the sediment. The sediment at Ollantaytambo has been assumed to be Type C, which is sandy clay loam, for these calculations, the particle size of sand is used. The canals are fed from mountain streams and rivers, so it is likely that rocks and pebbles are in the water, which are larger than sand, but the clay and silt particles are smaller than sand, so this is a good approximation. The particle size of course sand is $1 \mathrm{~mm}$, about 0.04 in (Williams et al., 2006).

The shear velocity can be expressed as:

$$
V_{*}=\sqrt{g R_{H} \sin \vartheta}
$$

Where

$V *=$ Shear velocity $(\mathrm{m} / \mathrm{s})$

$g=$ Acceleration due to gravity $\left(\mathrm{m} / \mathrm{s}^{2}\right)$

$R_{H}=$ Hydraulic radius of the channel (m or $\left.\mathrm{ft}\right)$

$\theta=$ Slope of the channel

The Shield's Parameter can be expressed as: 


$$
\tau_{*}=\frac{V_{*}^{2}}{(s-1) g d_{s}}
$$

Where

$$
\begin{aligned}
& \tau^{*}=\text { Shield's Parameter } \\
& V_{*}=\text { Shear velocity }(\mathrm{m} / \mathrm{s}) \\
& \mathrm{s}=\text { Specific gravity of sediment particle } \\
& g=\text { Acceleration due to gravity }\left(\mathrm{m} / \mathrm{s}^{2}\right) \\
& d_{s}=\text { Average particle size }(\mathrm{m})
\end{aligned}
$$

The specific gravity is the ratio of the density of a substance to the density of water. The specific gravity of sand is assumed to be 2.6; this means that sand is 2.6 times more dense than water (Williams et al., 2006).

Once the values for shear velocity, particle Reynolds number, and Shield's parameter are calculated for each canal, they are compared to the values on the Shield's Diagram for Sediment in Water, shown in Figure 7.

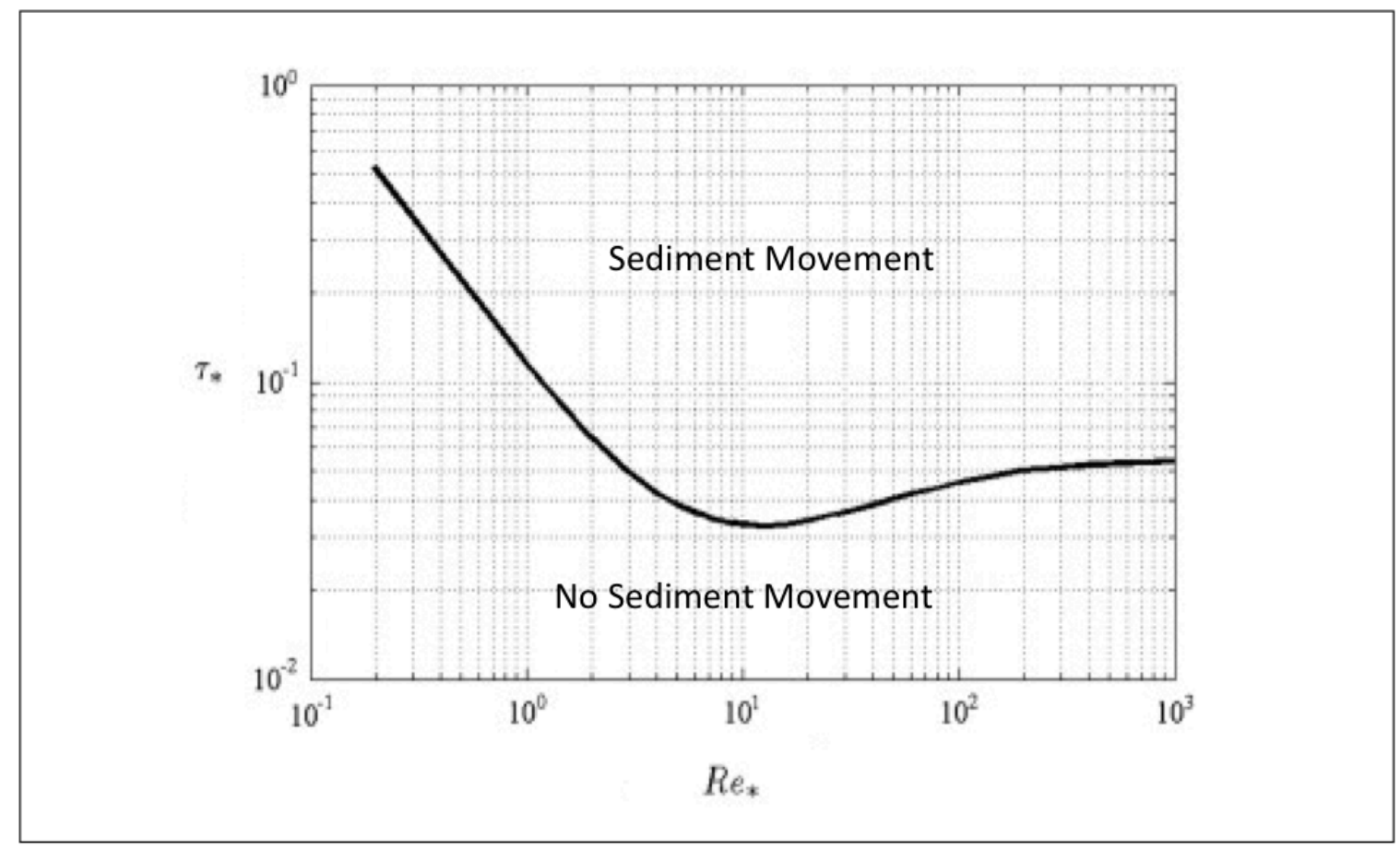

Figure 7. Shield's Diagram for Sediment in Water. Illustrates Relationship Between Sediment Movement, Particle Reynolds Number, and Shield's Parameter. Adapted from The Hydraulics of Open Channel Flow by H. Chansen, 1999. John Wiley \& Sons. 


\section{Evidence}

The fieldwork findings are explained in detail and the evidence found in each region of the Incamisana Watershed is introduced.

\section{Water Supply To Incamisana}

The Eight Terrace Complex is northwest and directly adjacent to the Incamisana. The Eight Terrace Complex is an important puzzle piece to this project. The walls on the Eight Terrace Complex have been reconstructed, along with canals that run along the base of the second and third terrace walls. The Inca did not finish the fourth terrace. One can see the construction line along the terrace; about halfway across the top terrace wall, there is a small step in the rock level, by a few inches, which shows us that the Inca were not done constructing the terrace, and had actually stopped in the middle of construction. The fifth through the eighth terraces are almost completely post-Inca, as these terraces may not have ever been finished in Inca times. Because of the reconstruction, it is assumed that the drains in the terrace walls are modern. While the team was collecting field data, Peruvian workers were reconstructing canals along the terraces; they added a catchment basin under the drop structure on Terrace Three, which was not there before reconstruction. This is an example of how modern reconstruction can cause evidence to be lost.

The Incamisana water complex is ceremonial religious water offering; historical patterns suggest that the Inca used pure, spring water for ceremonial purposes (Niles, 1987). That being said, the current feed to the Incamisana is from the Rio Patacancha via the Huaca Canal. From the Incamisana, the canal was explored about 0.5 kilometers up to where the canal meets the road. Farmers that use the canal water to irrigate their farms currently maintain this canal. The Manyaraqui Canal is the other modern supply canal, which diverts water into the Incamisana via a diversion after Fountain 4. The Manyaraqui Canal is named such because it runs to the Manyaraqui Sector, and alongside of it. This canal helps supply water to Fountains 5, 6, and 7, and the Manyaraqui Sector, and is currently the sole water source for the Princess Fountain. The Manyaraqui Sector and Princess Fountain are located at the south end of the Incamisana. These Fountains and Manyaraqui Sector can be seen in Figures 8 and 9. The location, aesthetics, and dimensions of the Manyaraqui Canal in Inca times are unknown, and it is impossible to determine whether it supplied water to the Incamisana or Manyaraqui Sector during Inca times. 


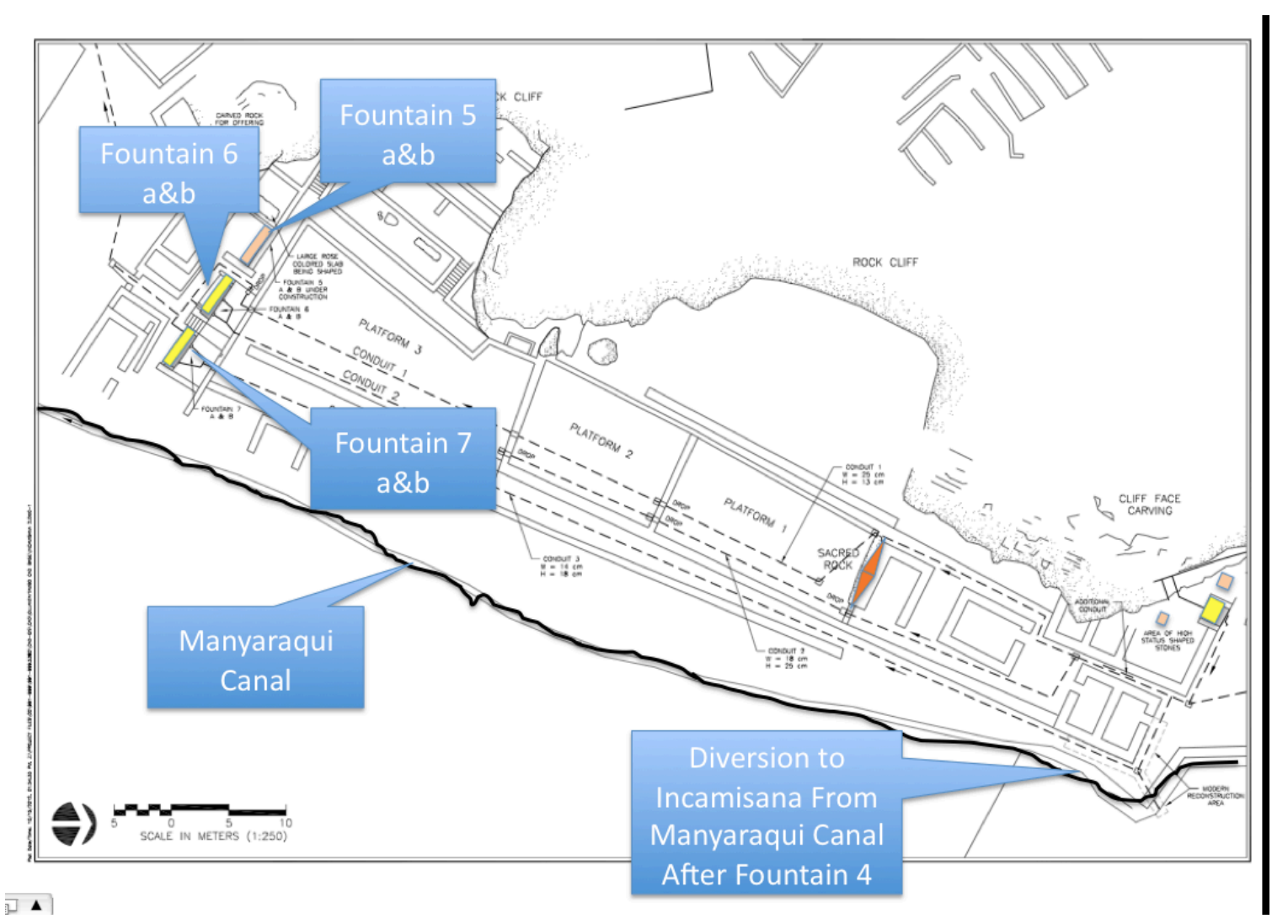

Figure 8. Diagram of Fountains 5, 6, and 7. CAD Drawing Locating the Fountains With Respect to the Manyaraqui Canal. (Wright Paleohydrological Institute) 


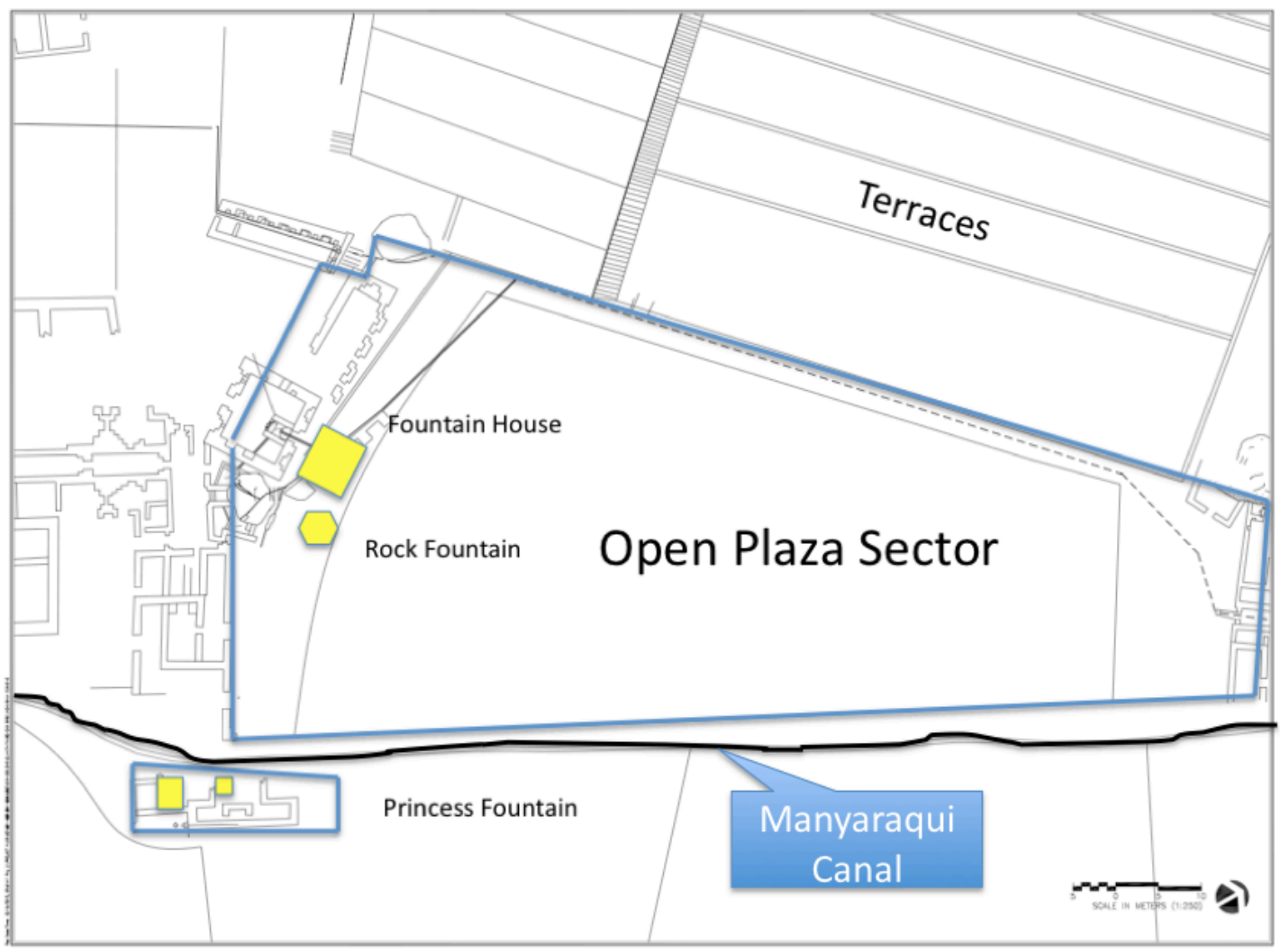

Figure 9. Diagram of the Manyaraqui Sector. CAD Drawing Locating the Manyaraqui Canal. (Wright Paleohydrological Institute)

The Huaca Canal is an ancient water supply to the Incamisana, and it runs from the Rio Patacancha, past the Huaca Stone at the north end of the terrace walls, to the third terrace where there is an original carved Inca drop structure at the top of the terrace. This suggests that the Inca did intend for water to flow to this drop structure, although there is no evidence of an ancient canal at the base of Terrace Three or Terrace Four. It is known that all the canals on the Eight Terrace Complex are modern, except the pre-Inca canal on the top of Terrace Eight, and the only piece of Inca canal is the drop structure on Terrace Three. The Terrace Complex can be seen in Figure 10. 


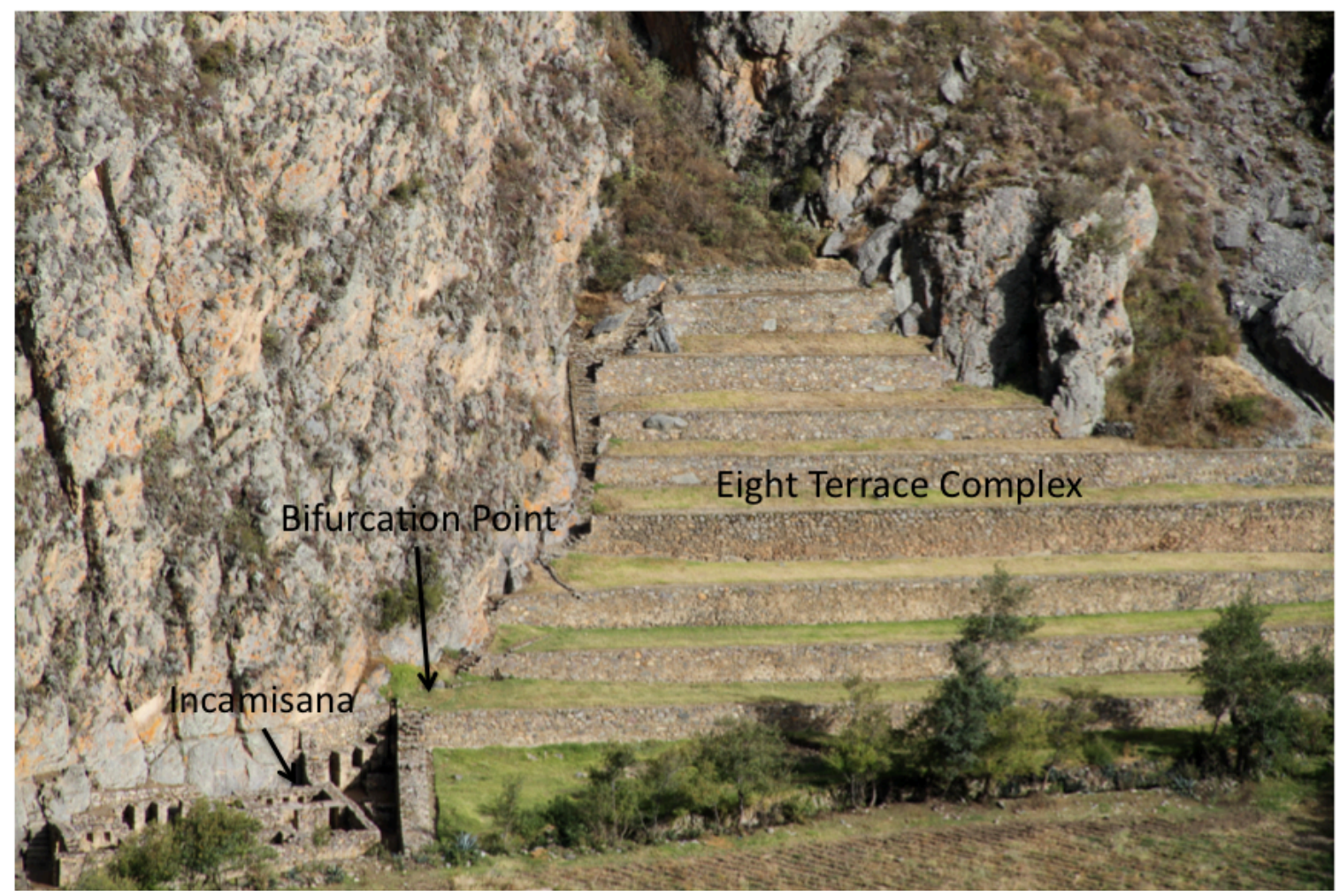

Figure 10. Eight Terrace Complex. Photo of Eight Terrace Complex, Bifurcation Point, and the Incamisana.

The water then runs along the Terrace Two, to the Bifurcation Point, which then directs the water into the Incamisana. This Bifurcation Point can be seen in Figure 11.

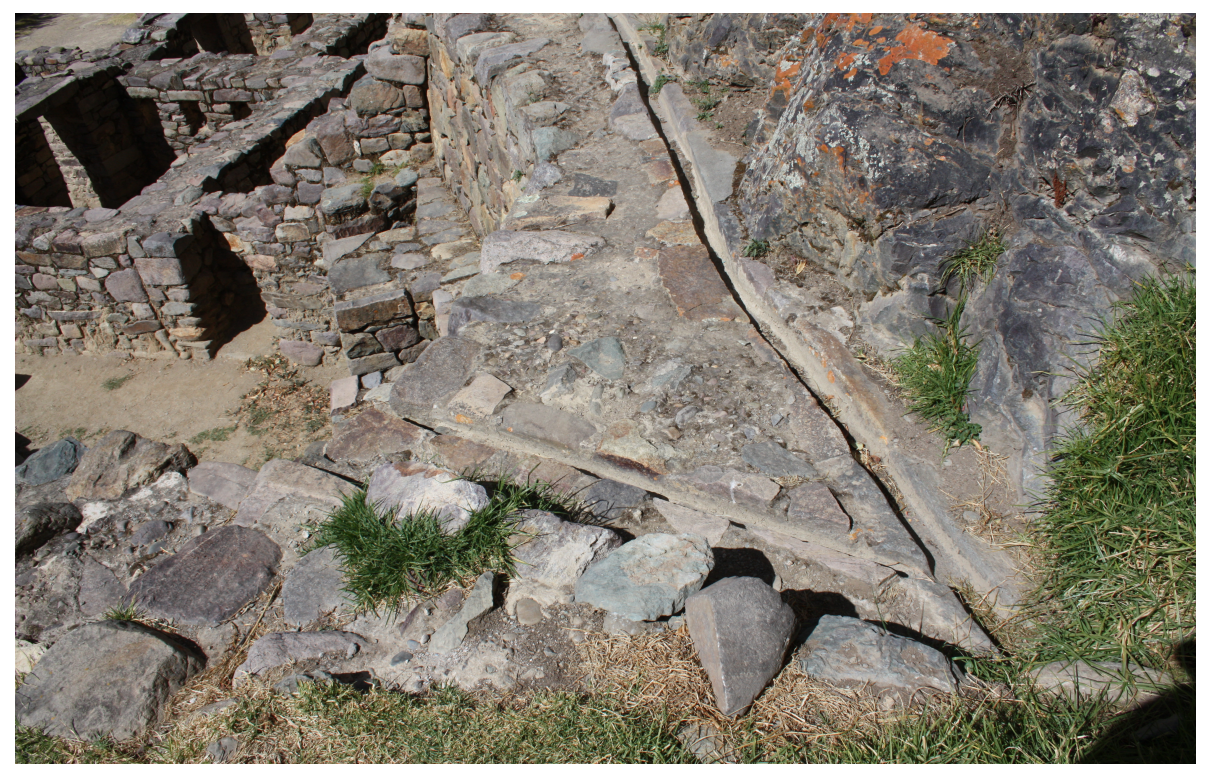

Figure 11. The Bifurcation Point. Photo of the Bifurcation Feeding the Incamisana. 
This modern Huaca Canal comes into the Eight Terrace Complex at a perfect grade to have used the drop structure, which is the only original drop structure on the Eight Terrace Complex, seen in Figure 12.

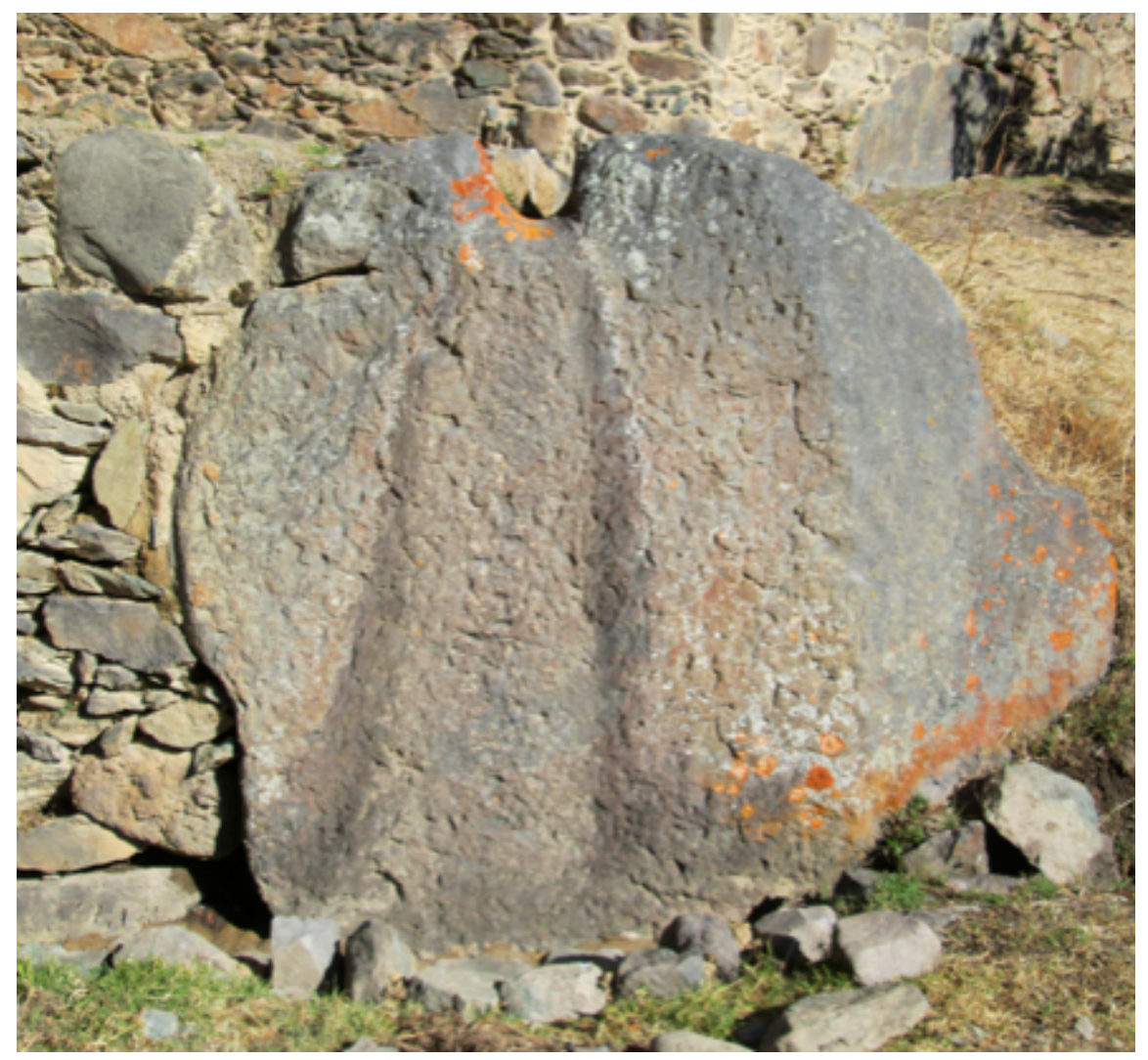

Figure 12. Notch Drop Structure. Photo of the Inca Drop Structure on Terrace Three.

The Huaca Canal is currently the sole water source of Fountains 1, 2, 3, and 4. These fountains along with the Bifurcation Point can bee seen in Figure 13. 


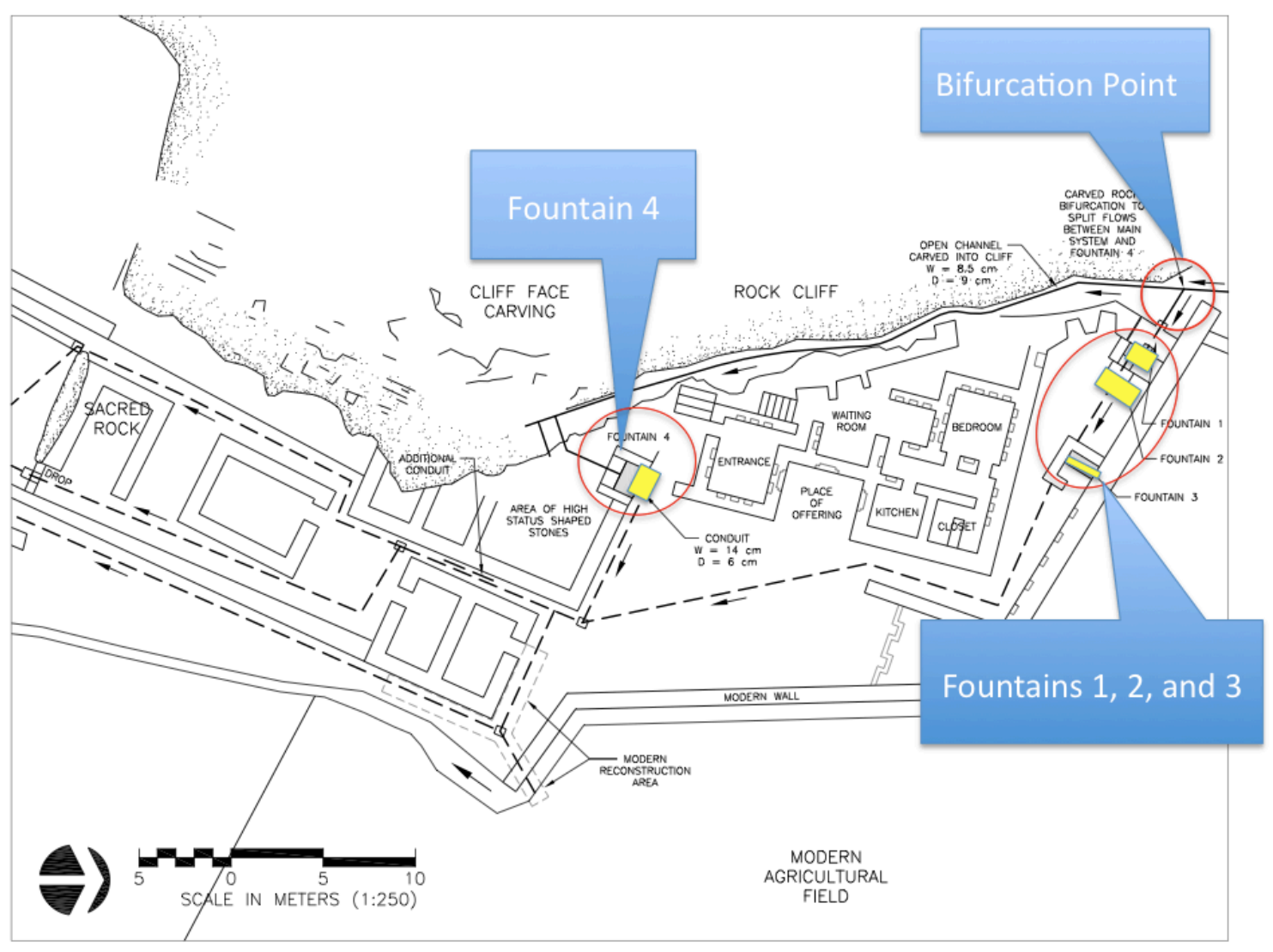

Figure 13. Diagram of Fountains 1, 2, 3, and 4. CAD Drawing Locating the Fountains With Respect to the Bifurcation Point. (Wright Paleohydrological Institute)

A key finding was that there is field evidence for a source that could have carried the water for the Incamisana from more than $2 \mathrm{~km}$ away via the Bandolista Canal, down to the Eight Terrace Complex. There is a pre-Inca, Killke, canal above of the eighth terrace, and the water was brought into it by means of the pre-Inca Bandolista Canal. At the northern end of the seventh terrace there is an original Inca canal piece carved into the stone, this piece of canal directs the water from the terraces, across the terrace stairway to the rock-face along the side of the mountain. It appears that the water was intended to flow along a canal running along the stairway on the south side of the Eight Terrace Complex to the Bifurcation Point, where it enters the Incamisana.

The Bandolista Canal, the Huaca Canal, and the Manyaraqui Canal as seen in Figures 14 and 15, Incamisana Supply Canal Map and Photo. 


\section{Supply Canals to Incamisana}

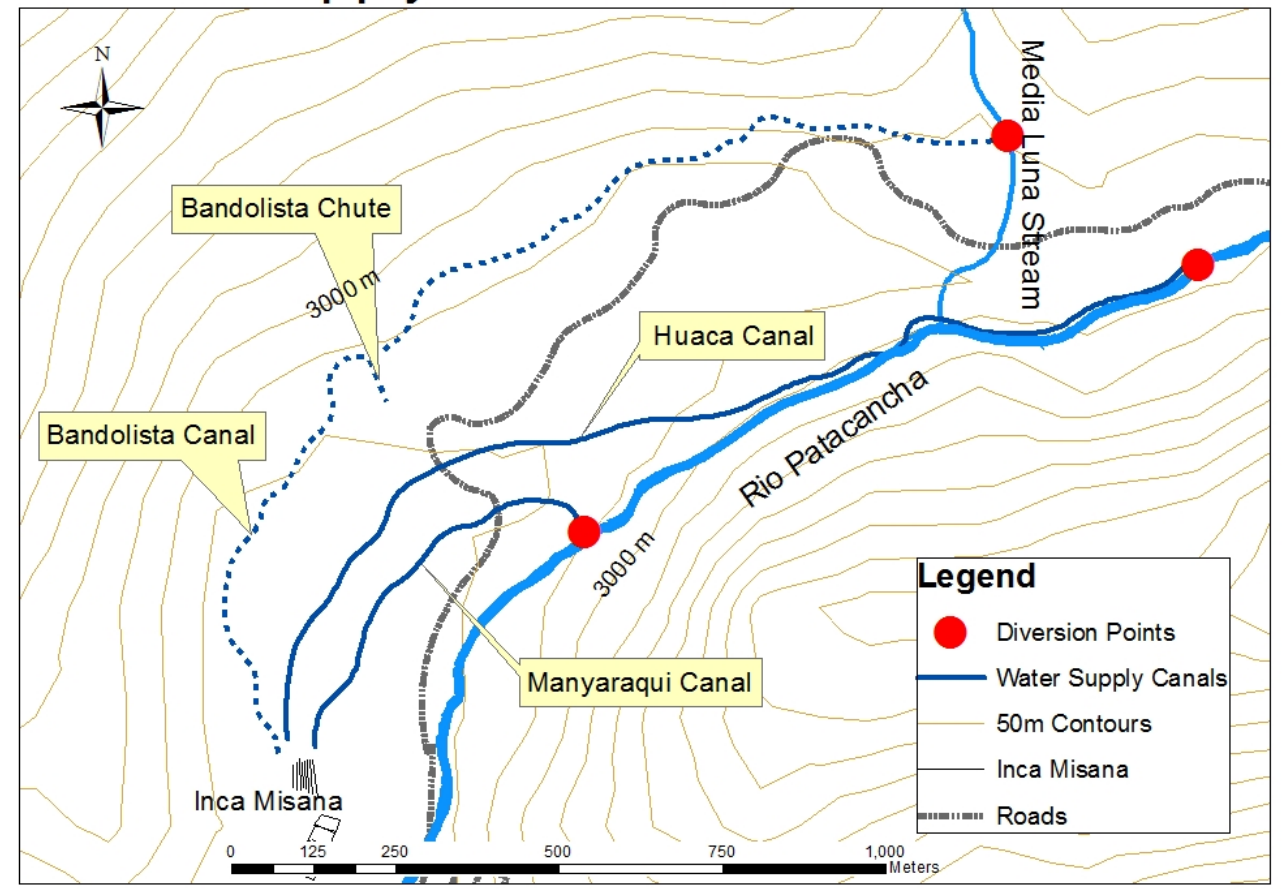

Figure 14. Supply Canals to Incamisana. Map of the Three Water Supply Canals to the Incamisana. 


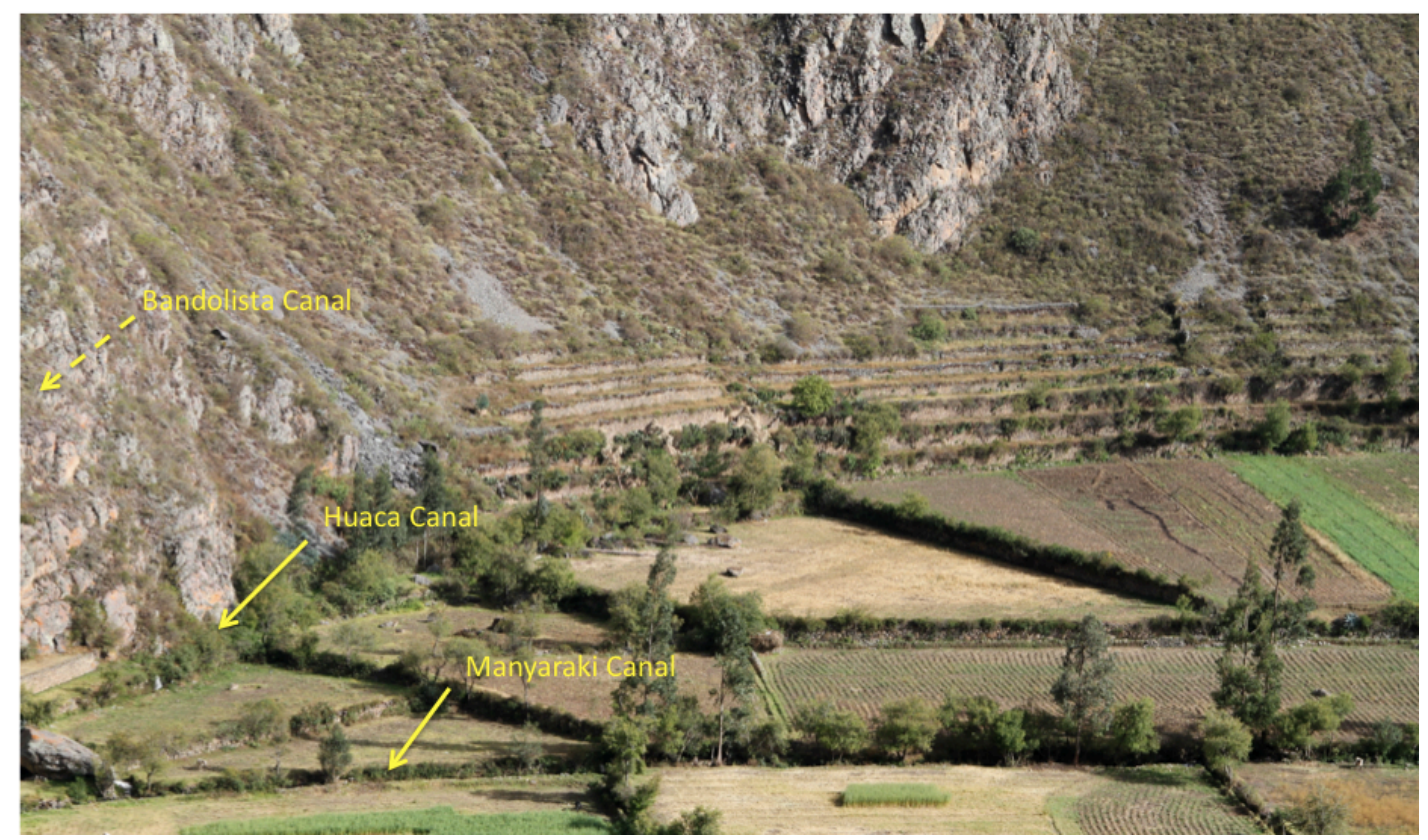

Figure 15. Supply Canals to Incamisana. Photo of the Three Water Supply Canals as They Enter the Incamisana.

Evidence suggests that the Incamisana Complex was not completed during Inca times. Although the Incamisana was not completed, field evidence indicates that the buildings on the northern portion of the temple had been plastered and that the water temple infrastructure was in place. Additionally, artifacts such as plates and cookware have been found in this area. Directly below the carved channel, Bifurcation Point. Fountain $4 \mathrm{a}$ and $4 \mathrm{~b}$ especially, show archaeological evidence of being unfinished, as can be seen in Figure 16. 


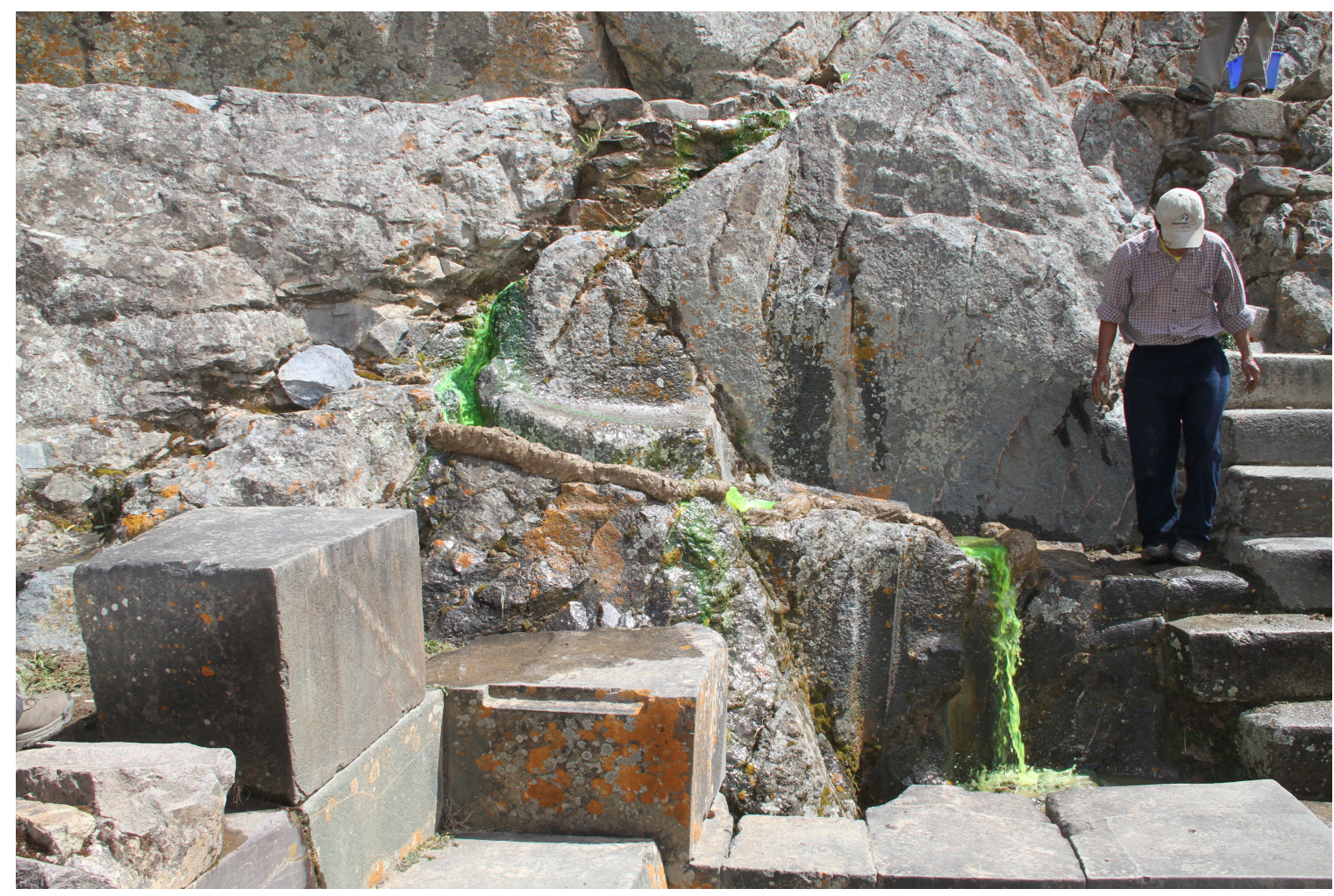

Figure 16. Unfinished Fountain 4. Photo of Fountains that were Unfinished.

Dr. Gibaja Oviedo, the resident archaeologist from the INC, can point out the stones in this area are misplaced, and one can tell by how the rocks fit together. The rocks have construction lines carved into them where other rocks were meant to fit, and by looking at these lines she could determine that many rocks are out of place. Directly next to Fountain 4 is a building with an unusual doorway for the Inca because upon entering the building, one is facing a wall and must take an immediate 90 -degree turn to the left. A design such as this one is not typical among Inca buildings. This is again due to the fact that the Incamisana was not completed, and this building was actually not a building at all, but a construction area for carving and storing stones. It was possible to conclude that the fountains and water systems of the Incamisana, and at least four additional fountains, were operational at the time of abandonment.

\section{Bandolista}

A substantial amount of time in the field was spent investigating the Bandolista canal. The first day of fieldwork led to us to a vertical canal stemming from the known Bandolista Canal that the research team had not seen in 2011, although Dr. Gibaja Oviedo knew of it. This chute is referred to as the Bandolista Chute. The Bandolista Chute appears to be constructed by the Inca. The pieces of the Bandolista Canal that are up-valley from the chute also have evidence of being constructed by the Inca, this is the section between the Bandolista Chute and the Media Luna Stream. The section of the Bandolista Canal that is down-valley from the chute, between the chute and the Incamisana appears to be pre-Inca, with no evidence of Inca reconstruction. 
One of the most exciting experience at Ollantaytambo was following pieces of this canal that once ran from the Media Luna Terraces to a close proximity of the Incamisana, and may have fed, or been intended to feed the Incamisana. The canal is fed from a Bocatoma, or Inca Diversion, from the Puma Paqcha River, or Media Luna Stream. This diversion is located at the bottom of the Media Luna terraces. The diversion feeds a canal that has evidence of existing from the Puma Paqcha, or Media Luna Stream and extends through Bandolista, to just above the Eight Terrace Complex. This is the canal that has been identified as the Bandolista Canal, and its current state can be seen in Figure 17.

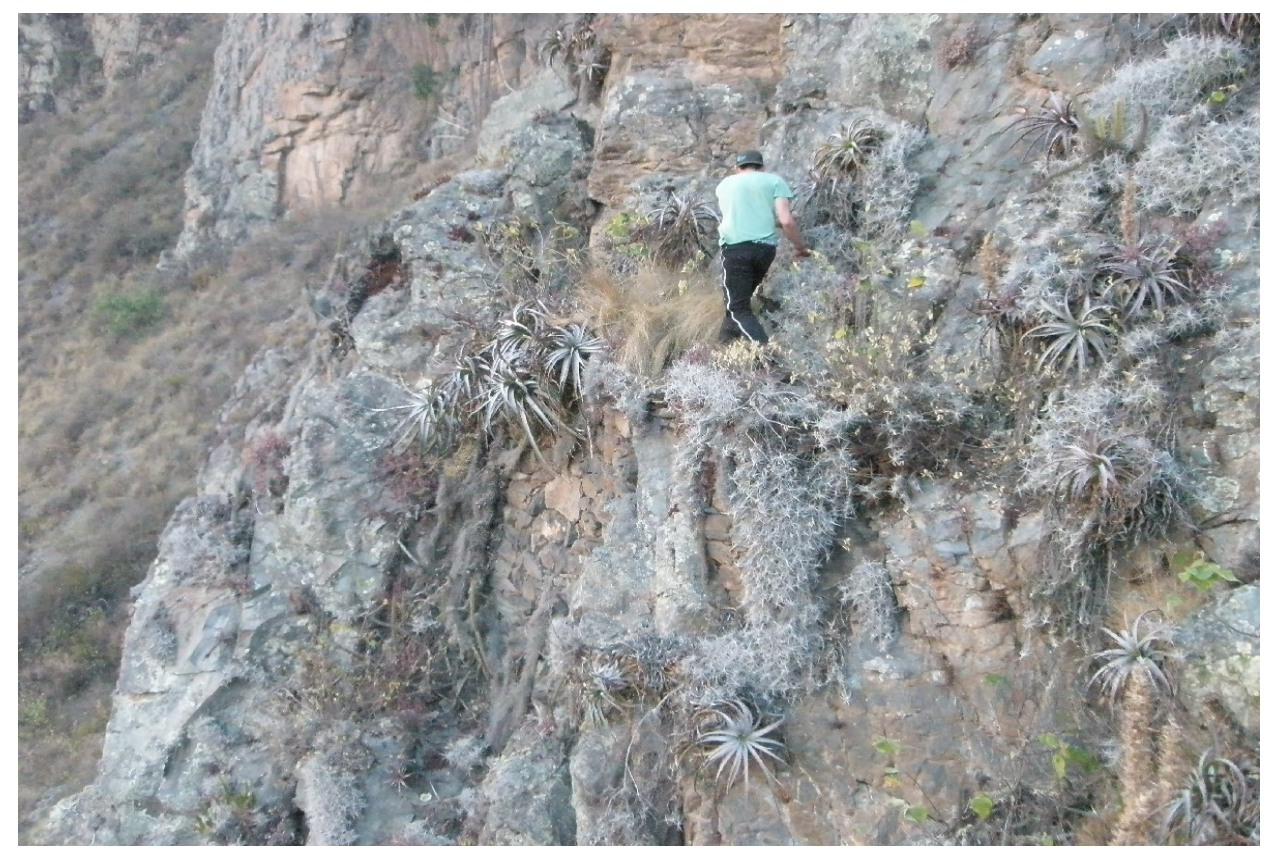

Figure 17. Bandolista Canal Photo. Photo of the Bandolista Canal, the Existing Evidence is a Supporting Wall Along the Rock Face.

The Bandolista Chute, which comes down off the Bandolista Canal can be seen from the road in the town of Bandolista. Upon further inspection, it was found that it was fed from the Bandolista Canal, its purpose is unknown, but it could have been a diversion for when water was not needed down-valley. Segments of this canal can be followed towards the Incamisana; landslides break the segments. There is evidence of this canal along the mountainside almost directly to the Incamisana, where it became too dangerous to follow it because of the topography. From this point, the Bandolista canal continues in sections around two mountain faces towards the Incamisana. Along the second rock face north of the Incamisana, evidence was found of two pieces of canal that once carried water down the mountain towards the Eight Terrace Complex. The first section is straight but the second resembles a triangular piece of canal used to lower the grade of the canal at a slow rate to keep the water from reaching critical velocity. After these two points the canal disappears for about 100m towards the Incamisana. From there, a few pieces can be found until the last rock face before the Incamisana. The last major piece of the canal is located on the last rock face before the Eight Terrace Complex. Around this rock face there are intact portions of a canal that run to the top of Terrace Eight. 
At the top of the Terrace Eight, there is a natural indention in the rock face that could have been used to transport water from the last part of the canal down to the top of the terraces. The last part of the canal is about $6.5 \mathrm{~m}$ higher than the top of Terrace Eight. The original Inca canal on the top of Terrace Eight suggests that water was intended to be there. The natural rock face that leads the last part of the Bandolista Canal down the 6.5 $\mathrm{m}$ drop ends in the middle of the canal at the top of Terrace Eight, which can be seen in Figure 18.

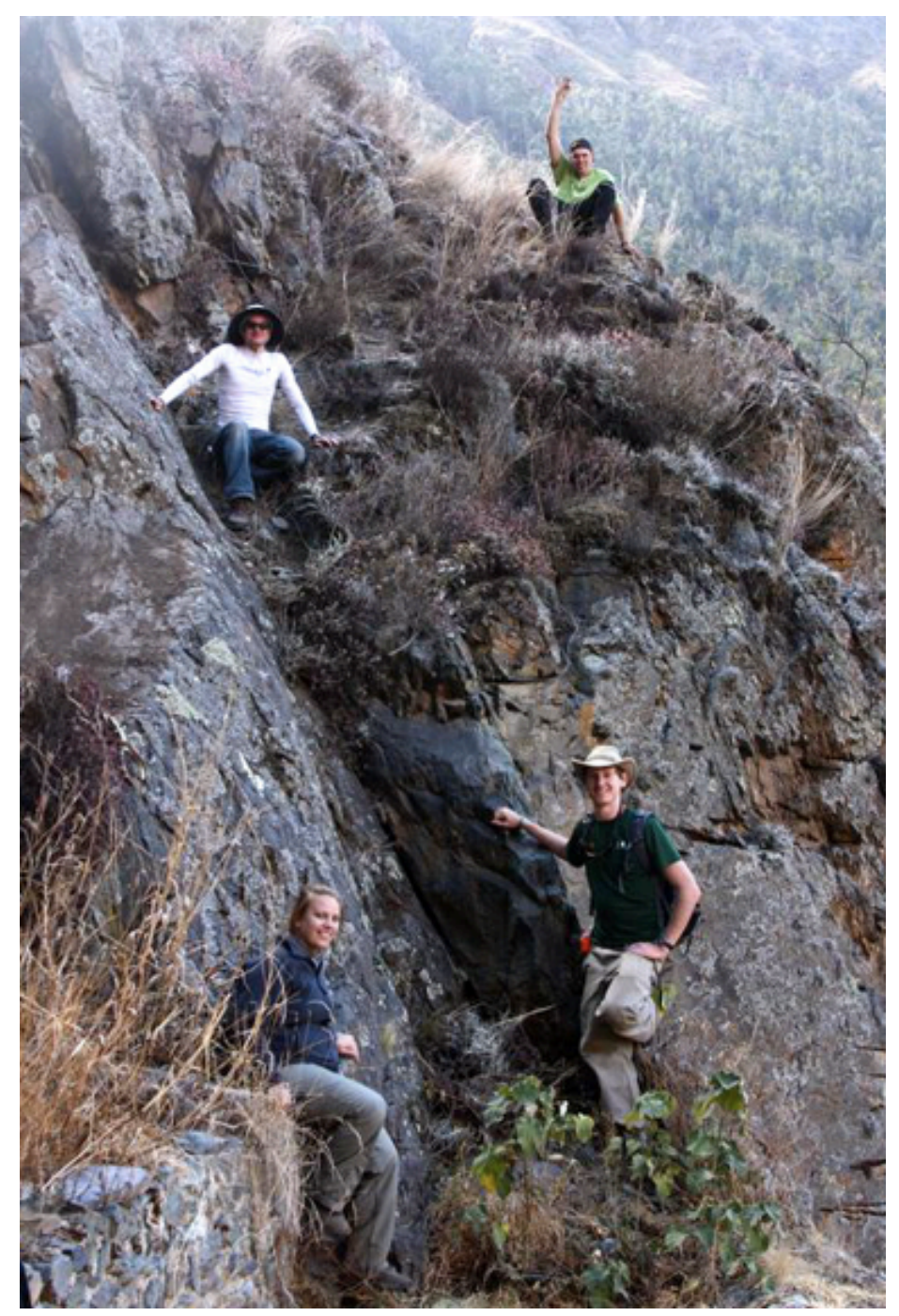

Figure 18. End of Bandolista Canal to Top of Terrace Eight. Photo of the Last Point of Evidence of the Bandolista Canal to the Canal Above Terrace Eight. (Where the man is raising his hand is the last piece of evidence of the Bandolista Canal, and the man and woman at the bottom are standing on the top of Terrace Eight.)

From this natural rock face, the canal continues across to the other side where it begins to drop down the side of the stairway to the Incamisana Bifurcation Point. 
Upstream of the Bandolista Chute, the Bandolista Canal was traced through the town of Bandolista to Media Luna. The canal above Bandolista is severely damaged but evidence still exists. From Bandolista to Media Luna, the canal slopes slightly upward at all times and is mostly located on the side of cliff faces. Many pieces of the canal are well preserved are used a base to hold a pipe which currently carries domestic water to Bandolista. The canal exists from the Bocatoma and downstream for a good $50 \mathrm{~m}$, where evidence becomes discontinuous all the way to Bandolista due to landslides. The Bocatoma is still intact and looks as if it may be used today for agricultural purposes. The likely canal route was documented with GPS waypoints that are plotted in Figure 19.

\section{Supply Canals to Incamisana}

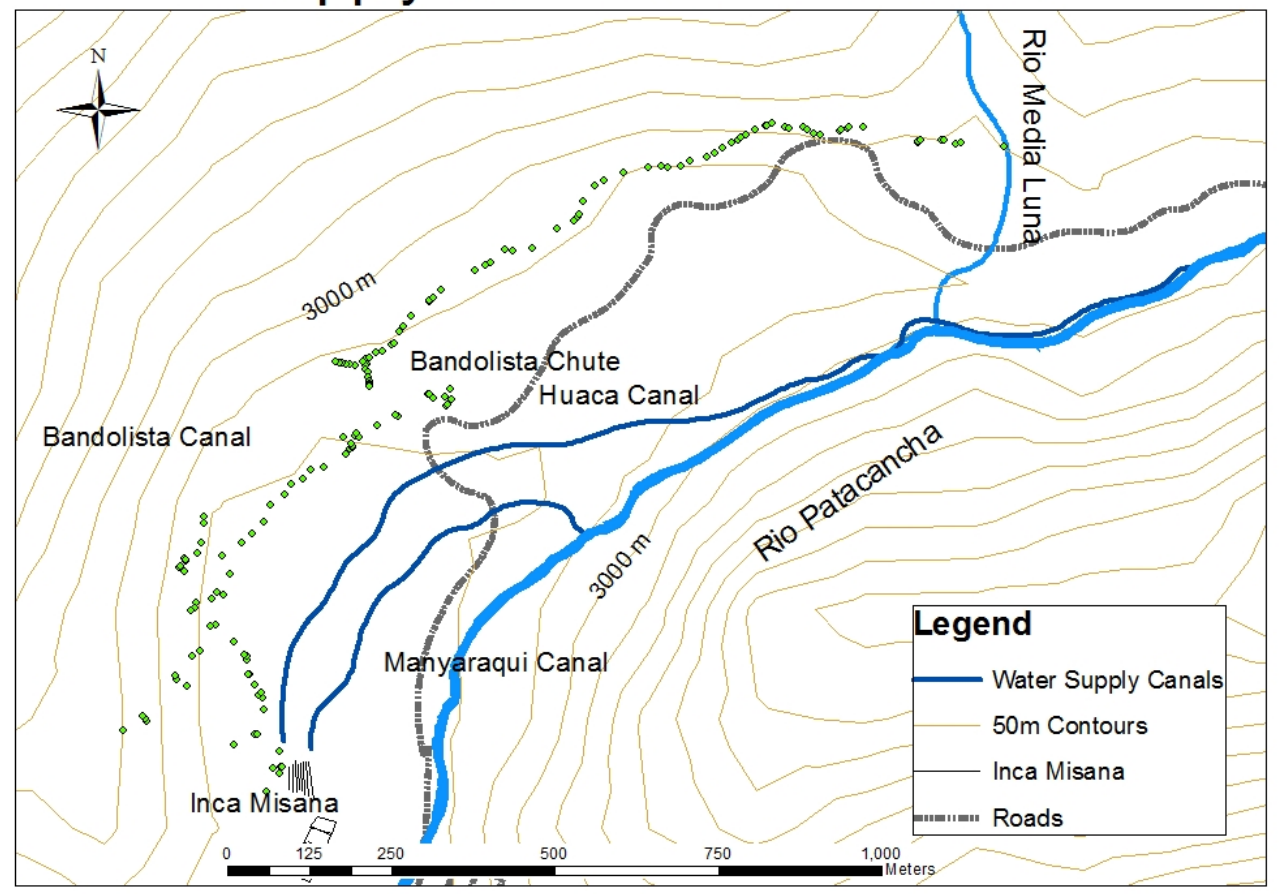

Figure 19. Bandolista GPS Trek. Water Supply Map to the Incamisana Showing the GPS Points Taken During Fieldwork.

The Bandolista Canal is a key finding in the field research, because it shows us another possible source, besides the Huaca Canal, to the Incamisana. There is significant evidence that water was brought from the Media Luna Stream almost all the way to the Incamisana. The Bandolista Canal was likely Killke, therefore, the location of Incamisana could have been chosen because of the existing canal.

There are agricultural terraces along the valley in Bandolista, from the Incamisana, all the way to the Puma Paqcha or Media Luna Stream. These are beautiful agricultural terraces that the Inca likely used to grow corn. These terraces have flying 
stairs, and they may have been built in this location to stabilize the mountain below the Bandolista Canal in order to support the canal.

\section{Puma Paqcha/Media Luna}

The first mountain stream up-valley from the Incamisana is locally known as the Media Luna Stream, also known as the Puma Paqcha. The Inca Diversion at Media Luna Stream is on the down-valley side of the creek, and it works as an input to the Bandolista Canal, and the water that does not divert to the Bandolista canal comes back down into the Media Luna Stream. This is a true Inca diversion, and the evidence is that the diversion is completely intact, and as previously stated, water still runs through it.

Just up-valley from the Puma Paqcha or Media Luna Stream, there is a set of Terrace Canals. There are clear canals on either side of the terraces, and also canals that run down the terraces from one canal to the other. Looking at the terraces, the canal on the right of the terraces is pre-Inca, and the one on the left side is Inca. These can be seen in Figure 20.

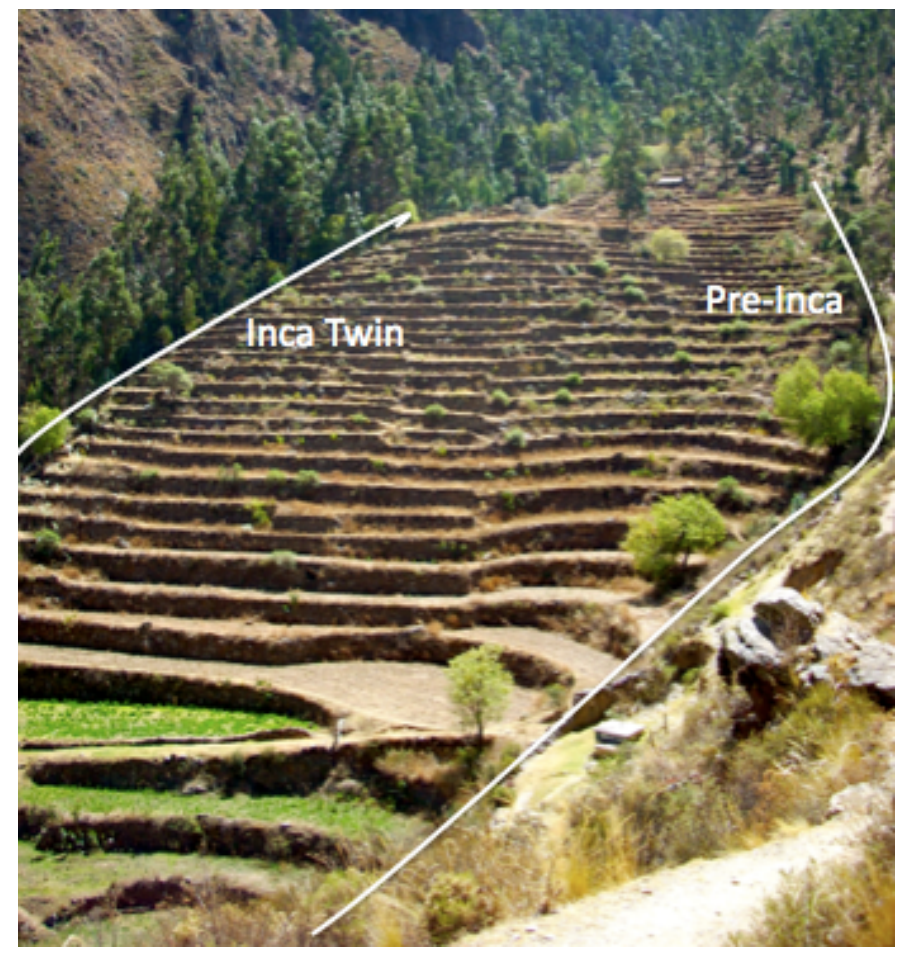

Figure 20. Media Luna Terraces with Pre-Inca Canal and Inca Twin Canal. Photo of the Media Luna Terraces with the Irrigation Canals Along Each Side.

There is a drop structure on each terrace, and then a slight slope on each of the terraces. This means that the canals are vertical, run along the edge of the terraces, and never have super-critical flow. The Media Luna Terraces are quite high, and were also likely to have been used to grow corn. These terraces were most likely not built for stability, but solely for agricultural purposes. The canals are clearly for irrigation. 


\section{Pandeloq Wayq'o/ Paqchapata}

The Media Luna Canal extends from the Pandeloq Wayq'o or Paqchapata Chute, and ends abruptly at a road crossing. It does not cross the Media Luna Terraces. The evidence of this canal is a supporting wall. There is sporadic evidence of the actual canal, and eventually all evidence is lost to landslides.

The Pandeloq Wayq'o, as it runs into the Rio Patacancha, eventually becomes the Paqchapata (or Chaqchapata) Chute. The Chute is extremely vertical, and has a high flow rate. The flow is supercritical, and one can tell by observation, as seen in Figure 21.

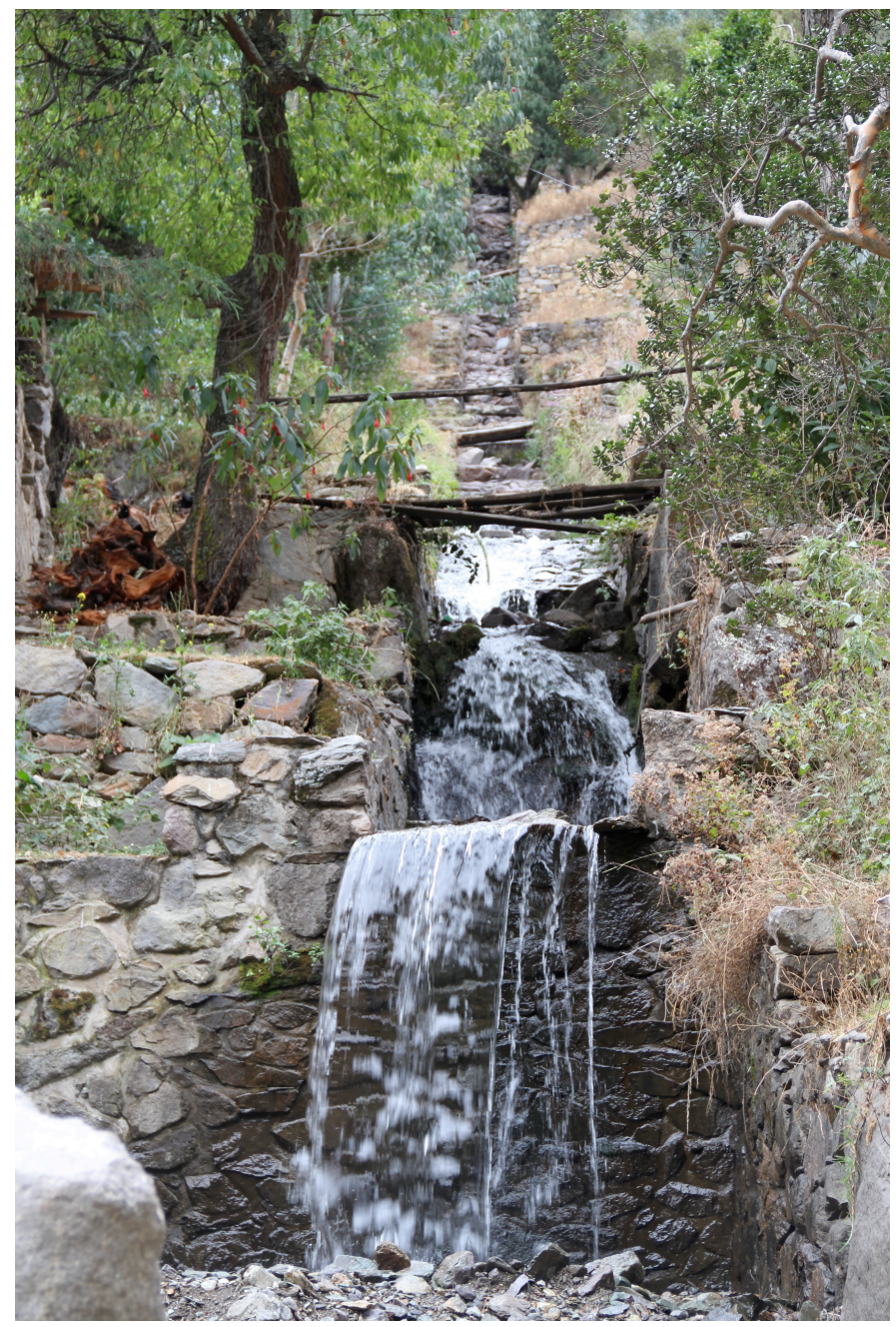

Figure 21. Paqchapata/Chaqchapata Chute. Photo of the Paqchapata Chute.

Lower Paqchapata Canal is the next canal upstream. The evidence is the canal that is still intact and carrying water. This canal runs up-valley, and ends at an agricultural terrace, where the slope breaks, so it can no longer run up-valley. 


\section{San Pablo}

The Musk'a Pujhio region is just downstream of the Rio San Pablo. The area is characterized by the Andenes Grandes, or Large Terraces. There are 645 steps from the road, up the side of the terraces, to the San Pablo Canal. This canal runs from the Rio San Pablo, down-valley to the edge of the large terraces. The terraces extend further up the mountain, but this is the extent of the investigation. The San Pablo Canal was flowing when we saw it, and it is defined with an obvious cross-section. The canal is currently used for irrigation, but it was diverted out before reaching the Andenes Grandes.

Another canal runs parallel to the San Pablo Canal and is located about halfway up the terraces, it is called the Musk'a Puijho Canal. This canal runs up-valley to the edge of the Andenes Grandes. This Inca canal is also still flowing, even during the dry season. The Musk'a Puijho Canal can be seen in Figure 22.

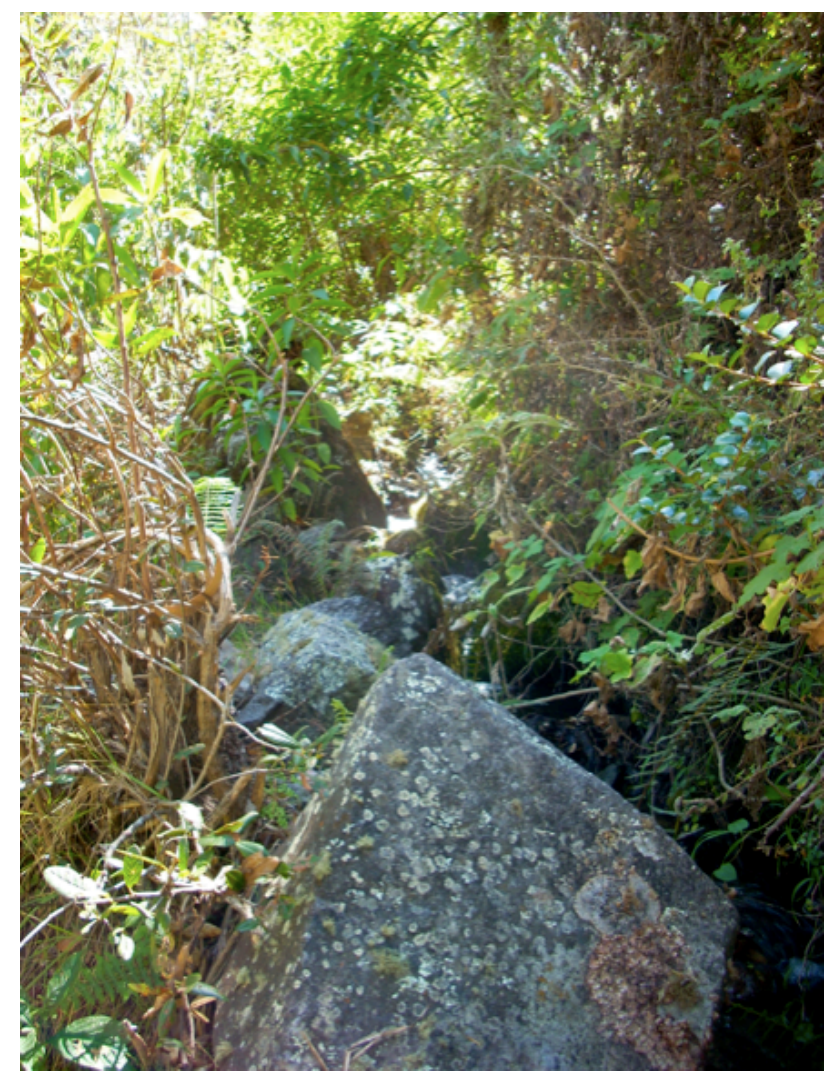

Figure 22. Musk'a Pujiho Canal. Photo of The Musk'a Puijho Canal that is Still Flowing.

Each of the mentioned Canals is located in the Canals map in Figure 23. 


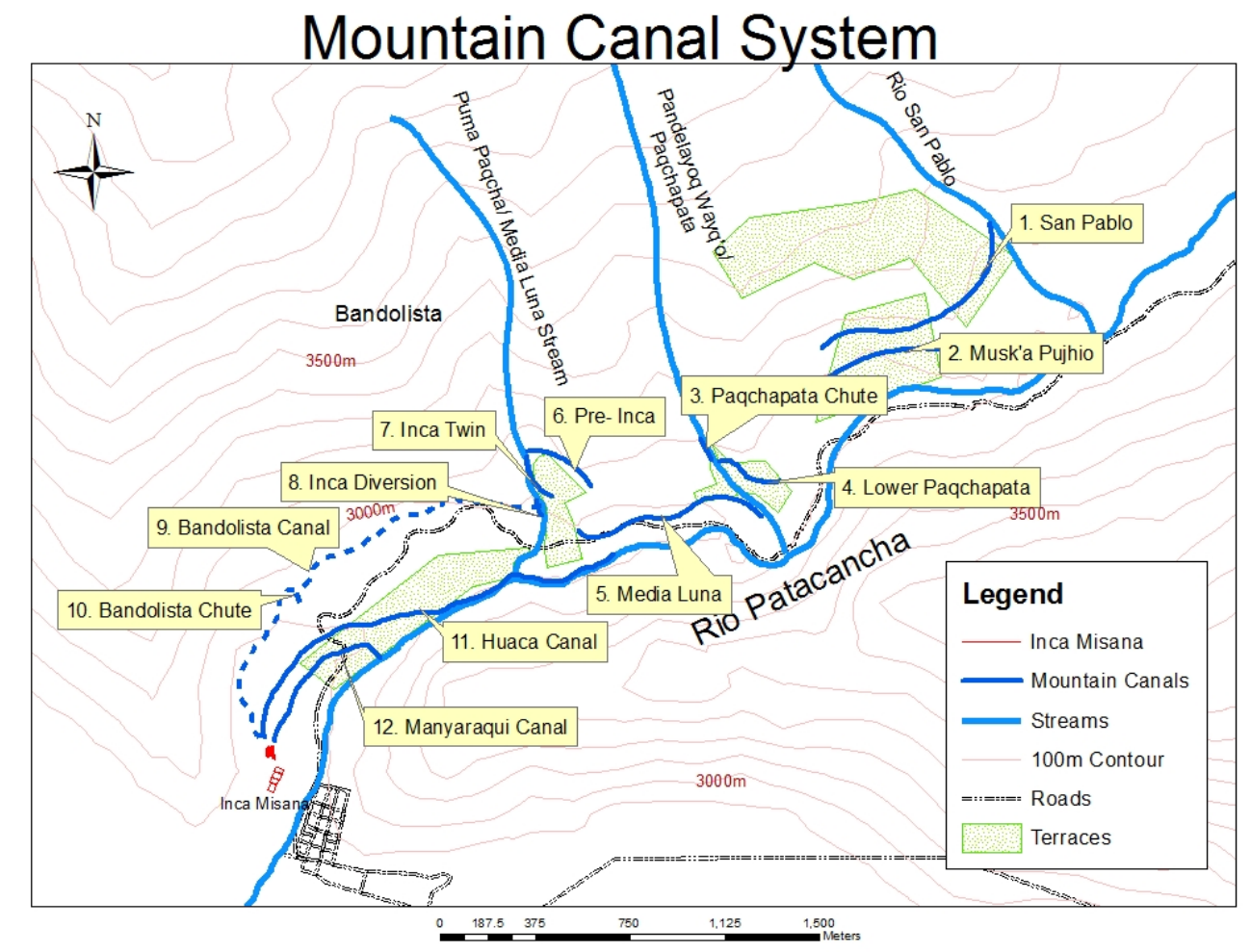

Figure 23. Canal Map. Map of the Canals Analyzed in Mountain Canal Model.

\section{Results and Discussion}

\section{Incamisana Watershed Model}

The Incamisana Watershed Model requires delineation of drainage basins, or watershed sub-basins. As previously mentioned, five basins were identified using a digital elevation model, or DEM, and the Spatial Analyst Toolbar in ArcGIS. More information about elevation data and the method to making the watershed model are outlined in a step-by-step tutorial in Appendix A. With adequate elevation data, which was $30 \mathrm{~m}$ by $30 \mathrm{~m}$, a map defining each of the watershed sub-basins could be created. It is shown in the Figure 24 below. 


\section{Incamisana Watershed}

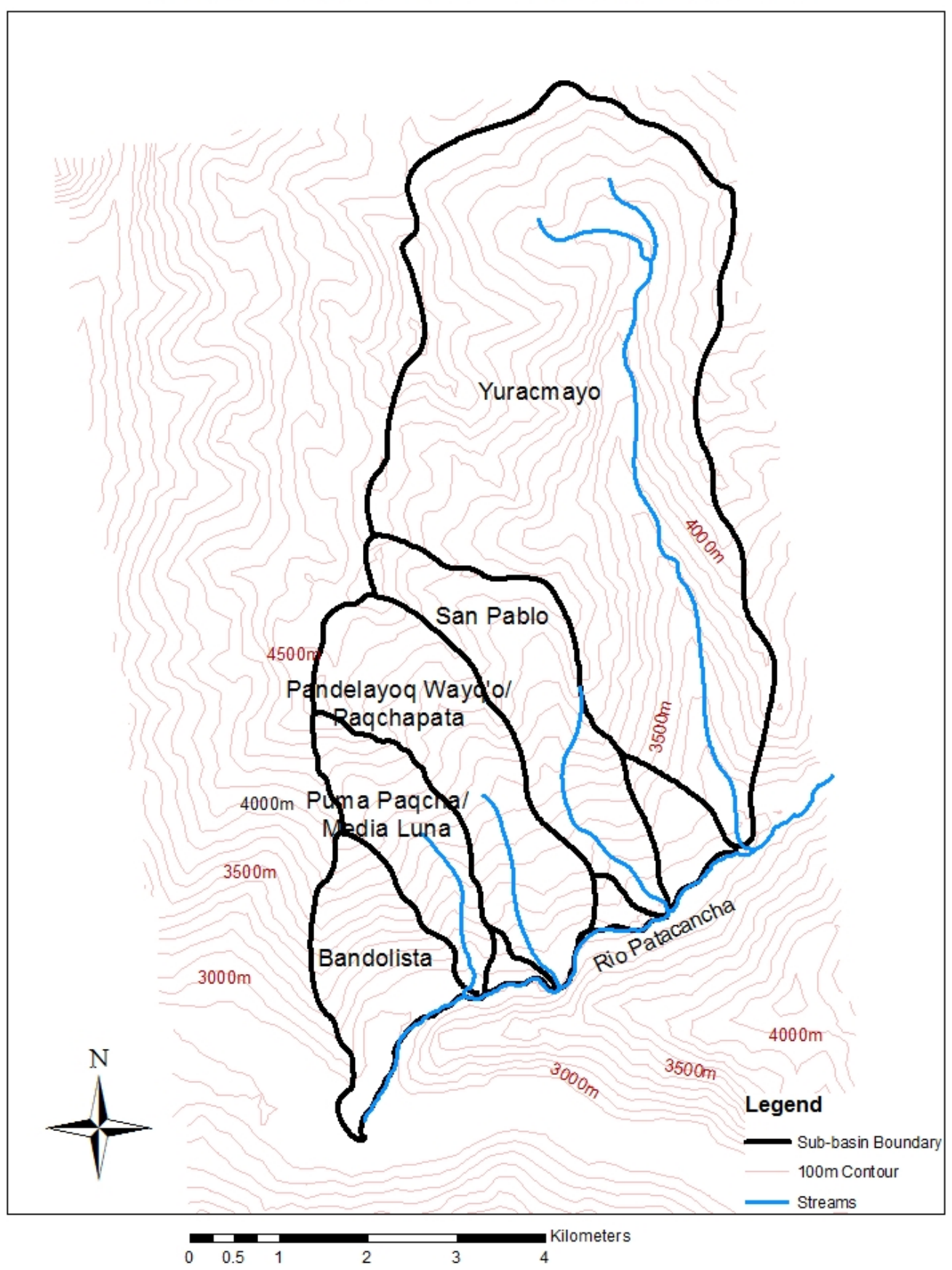

Figure 24. Incamisana Watershed. Delineated Sub-Basin Map.

This map in Figure 1 shows the sub-basins, Bandolista, Puma Paqcha/Media Luna, Pandelayoq Wayq'o/ Paqchapata San Pablo, and Yuracmayo. For reference, the Incamisana water offering is located in the Bandolista Basin. A flow direction map, 
which can be seen in Figure 25 below, was also created in ArcGIS 10. The stromwater within each sub-basin drains to one point, and this is illustrated in the Flow Direction Map.

\section{Incamisana Watershed}

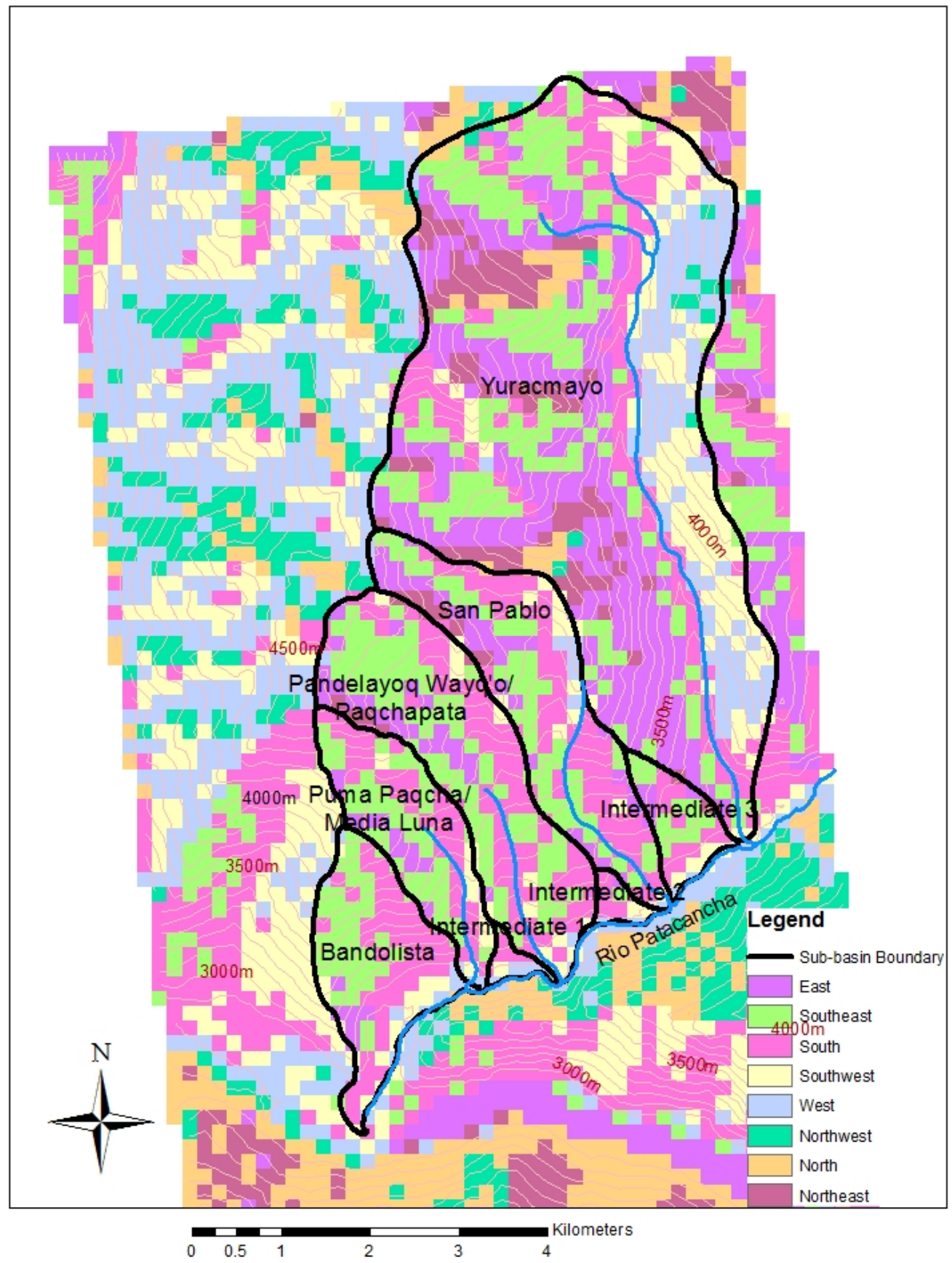

Figure 25. Flow Direction Map. Flow Direction Raster Map. 
The Flow Direction map shows the flow direction in each basin. It illustrates how the flow on each side of the watershed boundaries are flowing in different directions, and always flowing downhill into the streams of the Rio Patacancha.

Table 1 shows the area of each basin and the land cover for each basin, again the aerial photo Figure 2 can verify this.

\begin{tabular}{|c|c|c|c|c|c|c|c|}
\hline Sub-Basin & $\begin{array}{c}\text { Area } \\
\text { (hectares) }\end{array}$ & $\begin{array}{c}\text { Ratio of } \\
\text { Terraces }\end{array}$ & $\begin{array}{c}\text { Ratio of } \\
\text { Shrub/Scrub }\end{array}$ & $\begin{array}{c}\text { Ratio of } \\
\text { Trees }\end{array}$ & $\begin{array}{c}\text { Area of } \\
\text { Terraces } \\
\text { (hectares) }\end{array}$ & $\begin{array}{c}\text { Area of } \\
\text { Shrub/Scrub } \\
\text { (hectares) }\end{array}$ & $\begin{array}{c}\text { Area of } \\
\text { Trees } \\
\text { (hectares) }\end{array}$ \\
\hline Bandolista & 308 & 0.02 & 0.88 & 0.1 & 6.2 & 271 & 30.8 \\
\hline Puma Paqcha & 268 & 0.01 & 0.89 & 0.1 & 2.7 & 239 & 26.8 \\
\hline $\begin{array}{c}\text { Intermediate } \\
1\end{array}$ & 24 & 0.025 & 0.875 & 0.1 & 0.6 & 21 & 2.4 \\
\hline $\begin{array}{c}\text { Pandelayoq } \\
\text { Wayq'o }\end{array}$ & 508 & 0.01 & 0.89 & 0.1 & 5.1 & 452 & 50.8 \\
\hline $\begin{array}{c}\text { Intermediate } \\
2\end{array}$ & 46 & 0.1 & 0.8 & 0.1 & 4.6 & 37 & 4.6 \\
\hline $\begin{array}{c}\text { San Pablo } \\
\text { Sntermediate } \\
3\end{array}$ & 106 & 0.01 & 0.89 & 0.1 & 1.1 & 94 & 49.9 \\
\hline \begin{tabular}{c} 
Yuracmayo \\
\hline
\end{tabular} & 2280 & 0.002 & 0.898 & 0.1 & 4.6 & 2050 & 228 \\
\hline
\end{tabular}

Table 1: Area of Sub-basins and Land Cover

Table 1 shows that the "Intermediate basins" are much smaller than the subbasins, and the Yuracmayo Basin is much larger than any of the others. The Bandolista Basin has the greatest area of terraces, which is consistent with what was observed in the field. These ratios were those used to calculate the composite Curve Number for each sub-basin. The only land cover categories considered for this model are terraces, shrub/scrub, and trees. There are some residential areas, in the Town of Bandolista, and at the base of the Paqchapata Chute. These were not accounted for in the model because it is unclear how much of this land was used for residential purposes in ancient times, and the area is so small that it would have little impact on the runoff analysis.

Each sub-basin is characterized by it's own composite Curve Number, $C N$, Surface Storage, $S$, and Initial Abstraction, $I_{a}$. Once the composite Curve Numbers were calculated, Equation 4 was used to calculate Surface Storage, and Equation 2 was used to calculate the Initial Abstraction. The results are in Table 2 below. 


\begin{tabular}{|l|r|rr|rr|}
\hline Sub-Basin & \multicolumn{1}{|l|}{ CN } & \multicolumn{2}{|l|}{$S \mathrm{~mm}$ (in) } & $I_{a} \mathrm{~mm}$ (in) \\
\hline Bandolista & 71 & 104 & $(4)$ & 21 & $(0.8)$ \\
\hline Puma Paqcha & 71 & 104 & $(4)$ & 21 & $(0.8)$ \\
\hline Intermediate 1 & 71 & 104 & $(4)$ & 21 & $(0.8)$ \\
\hline $\begin{array}{l}\text { Pandelayoq } \\
\text { Wayq'o }\end{array}$ & 71 & 104 & $(4)$ & 21 & $(0.8)$ \\
\hline Intermediate 2 & 71 & 104 & $(4)$ & 21 & $(0.8)$ \\
\hline San Pablo & 71 & 104 & $(4)$ & 21 & $(0.8)$ \\
\hline Intermediate 3 & 71 & 104 & $(4)$ & 21 & $(0.8)$ \\
\hline Yuracmayo & 71 & 104 & $(4)$ & 21 & $(0.8)$ \\
\hline
\end{tabular}

Table 2: Composite Curve Numbers

Although the area of each sub-basin and the ratios for each land cover were very different, the composite Curve Numbers were all 71. This means that the depth of runoff, depth of Surface Storage, and depth of Initial Abstraction are approximately the same across the entire Incamisana Watershed. The Surface Storage is $104 \mathrm{~mm}$, which is about $4 \mathrm{in}$, and that is the depth of water the soil can absorb before rain accumulates on top of the soil surface as runoff. The Initial Abstraction is calculated to be $21 \mathrm{~mm}$, or $0.8 \mathrm{in}$. This is the depth of water that includes precipitation that is infiltrated, evaporated, intercepted by vegetation, and water that collects in surface depressions.

Another characteristic of each sub-basin is its time of concentration, or time it takes for the runoff to reach a maximum. Equations 5 and 6 were used to calculate the time of concentration, which is a function of the hydraulic length, $L$, slope of the terrain, $Y$, and the Curve Number, $C N$. The results are shown in Table 3. 


\begin{tabular}{|l|r|r|r|r|r|}
\hline \multicolumn{1}{|c|}{ Sub-Basin } & \multicolumn{1}{|l|}{$\mathrm{L}(\mathrm{m})$} & $\mathrm{CN}$ & $\mathrm{t}_{\mathrm{L}}$ (minutes) & $\mathrm{t}_{\mathrm{C}}$ (minutes) \\
\hline Bandolista & 2310 & 51.95 & 71 & 17 & 29 \\
\hline Puma Paqcha & 3775 & 46.36 & 71 & 27 & 45 \\
\hline Intermediate 1 & 715 & 27.97 & 71 & 9 & 15 \\
\hline $\begin{array}{l}\text { Pandelayoq } \\
\text { Wayq'o }\end{array}$ & 4975 & 39.20 & 71 & 37 & 62 \\
\hline Intermediate 2 & 690 & 43.48 & 71 & 7 & 12 \\
\hline San Pablo & 5665 & 31.77 & 71 & 46 & 76 \\
\hline Intermediate 3 & 1615 & 43.34 & 71 & 14 & 24 \\
\hline Yuracmayo & 9200 & 21.74 & 71 & 81 & 135 \\
\hline
\end{tabular}

Table 3: Lag Time and Time of Concentration

The area of the sub-basin is directly proportional to its hydraulic length, and since the $C N$ was the same for all the sub-basins, the hydraulic length is in turn directly proportional to the time of concentration. The larger the sub-basin, the longer it takes to reach its maximum runoff, and the longer it takes a raindrop to travel to the drain point of the watershed.

The available weather data for this model was limited. There has not bee a significant climate change in Peru since the time of the Inca, and the rainfall patters today are similar to what is was during Inca times (Wright, 2000).Urubamba and Cusco are the only big cities close to Ollantaytambo that collect rainfall data. Urubamba is $20 \mathrm{~km}$ from Ollantaytambo, and has the same elevation. Cusco is $60 \mathrm{~km}$ from Ollantaytambo, and is located at an elevation about $600 \mathrm{~m}$ higher than Ollantaytambo. That being said, historical monthly and annual precipitation data from Cusco and Urubamba was the only data available. The precipitation in Ollantaytambo is assumed to be similar to that at Urubamba and Cusco. Data from individual storms in Urubamba or Cusco was unavailable, so historical data was used to determine a design storm for Ollantaytambo.

Cusco rainfall data annual average and maximum annual rainfall from Pumayalli's paper on watershed modeling in Cusco were used. The maximum annual precipitation in Cusco is approximately $1020 \mathrm{~mm}$, and the average is $647 \mathrm{~mm}$ (2008). To approximate an average storm in Ollantaytambo, historical monthly precipitation from Urubamba is used. To calculate an average storm at Ollantaytambo, the monthly average rainfall data for Urubamba was used; the total monthly rainfall depth was divided by the days in that month with rainfall. Because of the pattern in the Cusco data, the average storm was multiplied by two, and this was assumed to be the extreme weather event. The runoff analysis results were invalid with this storm because the depth of initial abstraction was greater than the depth of the rainfall. 
It is then reasonable to assume there are some weather differences between Urubamba, Cusco, and Ollantaytambo. This may be due to the fact that each city is located in a different river valley, and there are mountains separating the cities. It is reasonable to conclude that the weather patterns may differ. This presents a limitation of this project. The lack of rainfall data in Ollantaytambo requires assumptions to be made. If actual rainfall data were available, it would improve the analysis.

The next step was to multiply the average storm by 3 . The analysis was run, and the results were reasonable. The rainfall data, as well as the average storm calculations and design storm calculations are shown in Table 4.

\begin{tabular}{|l|rr|r|rr|rr|}
\hline & \multicolumn{2}{|l|}{$\begin{array}{l}\text { Total } \\
\text { Rainfall } \\
\text { Month (in) }\end{array}$} & $\begin{array}{l}\text { Days } \\
\text { with } \\
\text { Rainfall }\end{array}$ & $\begin{array}{l}\text { Average } \\
\text { Storm } \\
\text { mm (in) }\end{array}$ & $\begin{array}{l}\text { Design } \\
\text { Storm } \\
\text { Rainfall } \\
\text { mm (in) }\end{array}$ \\
\hline Jan & 152 & $(6)$ & 18 & 8 & $(0.3)$ & 25 & $(1)$ \\
\hline Feb & 111 & $(4.4)$ & 14 & 8 & $(0.3)$ & 24 & $(0.9)$ \\
\hline Mar & 96 & $(3.8)$ & 15 & 6 & $(0.2)$ & 19 & $(0.7)$ \\
\hline Apr & 37 & $(1.5)$ & 6 & $6(0.2)$ & 19 & $(0.7)$ \\
\hline May & 7 & $(0.3)$ & 2 & $4(0.15)$ & 11 & $(0.4)$ \\
\hline Jun & 2 & $(0.1)$ & 1 & 2 & $(0.08)$ & 6 & $(0.2)$ \\
\hline Jul & 3 & $(0.11)$ & 3 & 1 & $(0.04)$ & 3 & $(0.11)$ \\
\hline Aug & 7 & $(0.3)$ & 3 & 2 & $(0.08)$ & 7 & $(0.3)$ \\
\hline Sep & 22 & $(0.9)$ & 5 & 4 & $(0.15)$ & 13 & $(0.5)$ \\
\hline Oct & 46 & $(1.8)$ & 9 & 5 & $(0.2)$ & 15 & $(0.6)$ \\
\hline Nov & 68 & $(2.7)$ & 11 & 6 & $(0.2)$ & 19 & $(0.75)$ \\
\hline Dec & 110 & $(4.3)$ & 16 & 7 & $(0.3)$ & 21 & $(0.8)$ \\
\hline
\end{tabular}

Table 4. Urubamba Rainfall Data (Total and Days). Adapted from "Climate Sacred Valley/Urubamba" from http://www.zoover.co.uk/peru/peru/sacred-valleyurubamba/weather.

This shows that a design storm is $25 \mathrm{~mm}$ of precipitation. Average storms generate little to no runoff, as the initial soil abstraction is approximately $21 \mathrm{~mm}$. Since the depth of precipitation for average monthly storms are well below the depth of initial soil abstraction, this indicates that under normal circumstances, there is little to no runoff, since most of the precipitation is infiltrated or intercepted by vegetation. 
Figure 25 illustrates the yearly variability of precipitation. This again shows how the minor the average storm in Ollantaytambo produces very little runoff, since an average storm is so small compared to the infiltration. The rainfall data shows that Ollantaytambo has a fairly arid climate. This being the case, it makes sense why the Inca and pre-Inca people developed such an extensive canal system.

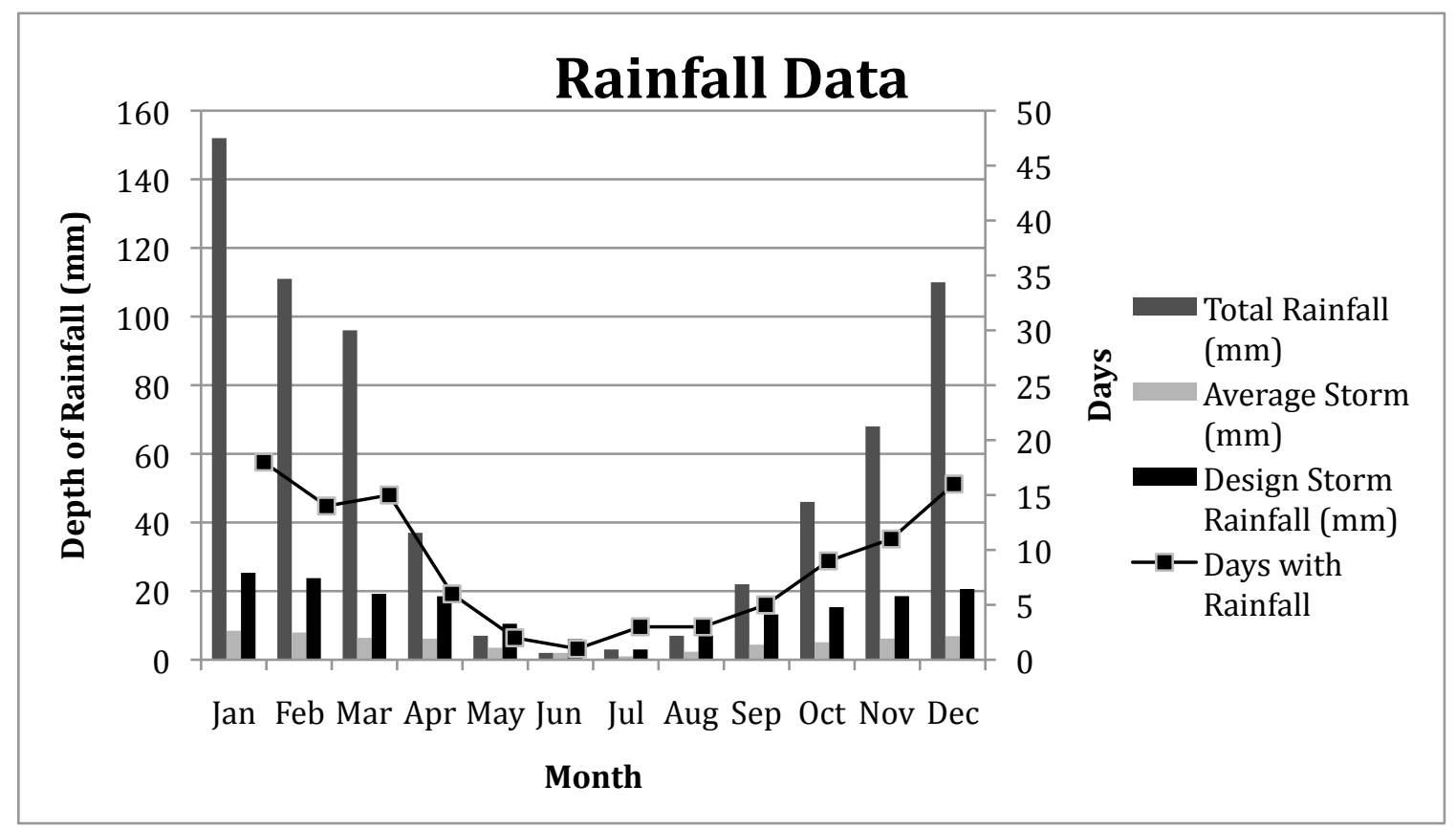

Figure 26. Urubamba Rainfall Data (Total and Days). Adapted from "Climate Sacred Valley/Urubamba" from http://www.zoover.co.uk/peru/peru/sacred-valleyurubamba/weather.

The peak runoff was computed using Technical Release (TR-55) Method. The depth of runoff, $Q$, was computed using Equation 3, and the results are shown in Table 5. 


\begin{tabular}{|l|r|rr|rr|r|l|}
\hline Sub-Basin & \multicolumn{1}{l|}{ CN } & \multicolumn{2}{|l|}{$S \mathrm{~mm}$ (in) } & $I_{a} \mathrm{~mm}$ (in) & P mm (in) & Q mm (in) \\
\hline Bandolista & 71 & 104 & $(4)$ & 21 & $(0.8)$ & $25(1)$ & $0.163(0.006)$ \\
\hline Puma Paqcha & 71 & 104 & $(4)$ & 21 & $(0.8)$ & $25(1)$ & $0.163(0.006)$ \\
\hline Intermediate 1 & 71 & 104 & $(4)$ & 21 & $(0.8)$ & $25(1)$ & $0.163(0.006)$ \\
\hline $\begin{array}{l}\text { Pandelayoq } \\
\text { Wayq'o }\end{array}$ & 71 & 104 & $(4)$ & 21 & $(0.8)$ & $25(1)$ & $0.163(0.006)$ \\
\hline Intermediate 2 & 71 & 104 & $(4)$ & 21 & $(0.8)$ & $25(1)$ & $0.163(0.006)$ \\
\hline San Pablo & 71 & 104 & $(4)$ & 21 & $(0.8)$ & $25(1)$ & $0.163(0.006)$ \\
\hline Intermediate 3 & 71 & 104 & $(4)$ & 21 & $(0.8)$ & $25(1)$ & $0.163(0.006)$ \\
\hline Yuracmayo & 71 & 104 & $(4)$ & 21 & $(0.8)$ & $25(1)$ & $0.163(0.006)$ \\
\hline
\end{tabular}

\section{Table 5: Runoff Depth for Design Storm}

Table 5 reiterates that the depth of runoff is a function of the $C N, S$, and $P$, and the depth of runoff, $Q$, is the same throughout the entire Incamisana Watershed. The depth of runoff is $0.163 \mathrm{~mm}$, or $0.006 \mathrm{in}$, which is very little. The soil in the watershed is pervious enough to minimize the runoff from the rainfall in the region.

The volume of runoff can be computed by multiplying the depth of runoff by the area of each sub-basin. We can also compute the total runoff for the entire Incamisana Watershed. The results are recorded in Table 6. 


\begin{tabular}{|l|r|r|r|r|r|}
\hline \multicolumn{1}{|c|}{ Sub-Basin } & Area (hectares) & Area $\left(\mathrm{mi}^{2}\right)$ & Area $\left(\mathrm{m}^{2}\right)$ & Q (m $\mathrm{m}^{3} /$ day $)$ & Q (gal/min) \\
\hline Bandolista & 308 & 1.19 & 3080000 & 502 & 92 \\
\hline Puma Paqcha & 268 & 1.03 & 2680000 & 437 & 80 \\
\hline Intermediate 1 & 24 & 0.09 & 240000 & 39 & 7 \\
\hline $\begin{array}{l}\text { Pandelayoq } \\
\text { Wayq'o }\end{array}$ & 508 & 1.96 & 5080000 & 828 & 152 \\
\hline Intermediate 2 & 46 & 0.18 & 460000 & 75 & 14 \\
\hline San Pablo & 499 & 1.93 & 4990000 & 814 & 149 \\
\hline Intermediate 3 & 106 & 0.41 & 1060000 & 173 & 32 \\
\hline Yuracmayo & 2280 & 8.80 & 22800000 & 3720 & 682 \\
\hline $\begin{array}{l}\text { Total } \\
\text { Watershed }\end{array}$ & $\mathbf{4 0 4 0}$ & $\mathbf{1 5 . 6}$ & $\mathbf{4 0 3 9 0 0 0 0}$ & $\mathbf{6 5 9 0}$ & $\mathbf{1 2 1 0}$ \\
\hline
\end{tabular}

Table 6: Volume of Runoff for Design Storm

The cumulative watershed runoff, $6590 \mathrm{~m}^{3} /$ day or $1210 \mathrm{gal} / \mathrm{min}$, is not significant for such a big area for an extreme weather event. The total area of the Incamisana Watershed is 4040 hectares, almost $16 \mathrm{mi}^{2}$. There is not a significant amount of rainfall in this area, and when there is, much of it is infiltrated.

\section{Mountain Canal System Model}

The data for canal dimensions are the averages of all the measurements taken during both field studies. These canals are labeled on the Canal Map in Figure 27. 


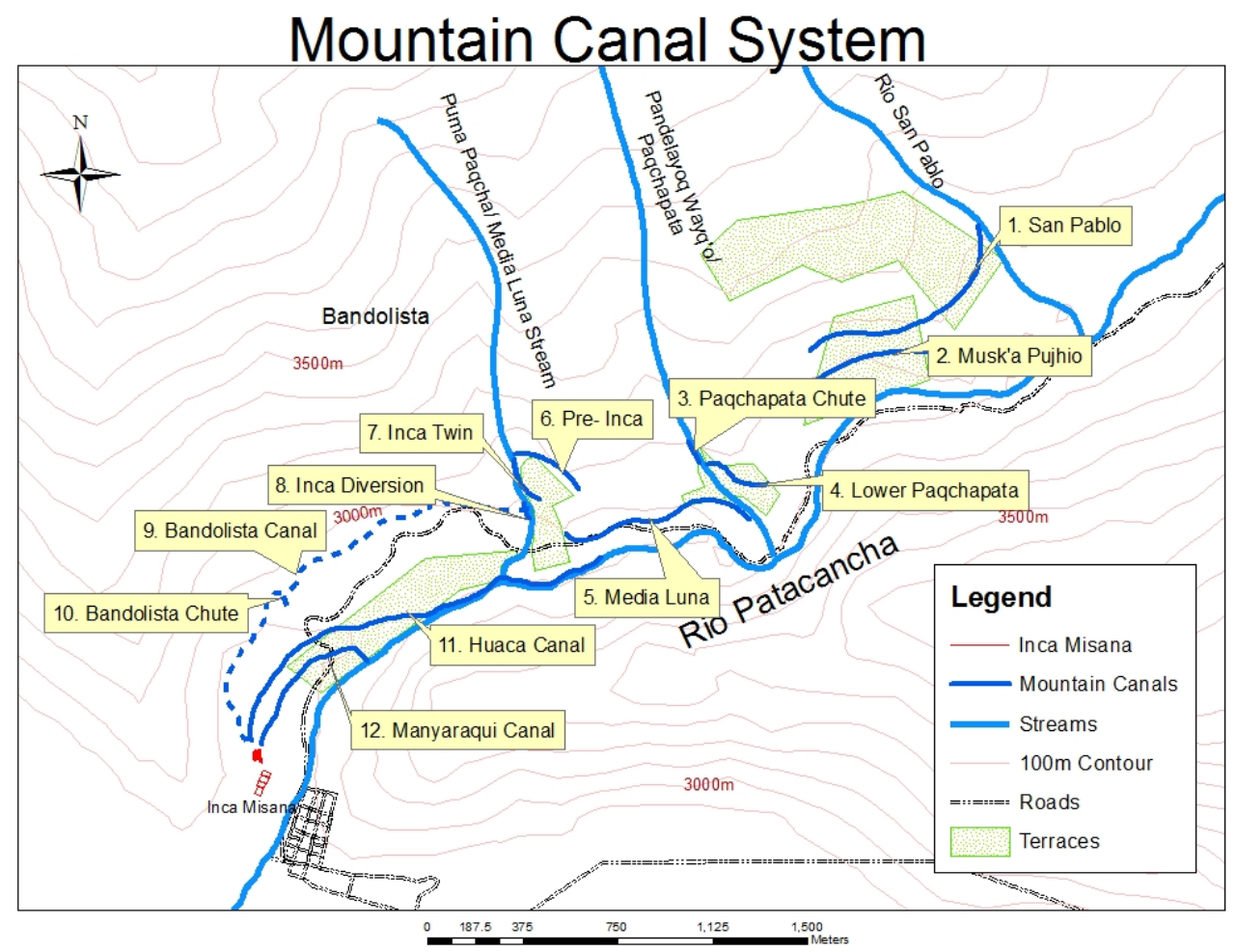

Figure 27. Canal Map. Map of the Canals Analyzed in Mountain Canal Model. 


\begin{tabular}{|l|r|r|r|r|r|}
\hline Canals & $B_{w}(\mathrm{~m})$ & $y(\mathrm{~m})$ & $A\left(\mathrm{~m}^{2}\right)$ & $R(\mathrm{~m})$ & \multicolumn{1}{l}{$S_{0}$} \\
\hline 1. Musk'a Pujhio & 0.45 & 0.3 & 0.14 & 0.13 & 0.07 \\
\hline 2. San Pablo & 0.3 & 0.24 & 0.07 & 0.09 & 0.01 \\
\hline 3.Paqchapata Chute & 2 & 1 & 2.00 & 0.50 & 0.5 \\
\hline 4. Lower Paqchapata & 0.45 & 0.25 & 0.11 & 0.12 & 0.02 \\
\hline 5. Media Luna & 0.35 & 0.25 & 0.09 & 0.10 & 0.015 \\
\hline 6. Pre-Inca & 0.4 & 0.25 & 0.10 & 0.11 & 0.02 \\
\hline 7. Inca Twin & 0.4 & 0.25 & 0.10 & 0.11 & 0.02 \\
\hline 8. Inca Diversion & 0.4 & 0.25 & 0.10 & 0.11 & 0.6 \\
\hline 9. Bandolista Canal & 0.29 & 0.3 & 0.09 & 0.10 & 0.02 \\
\hline 10. Bandolista Chute & 0.36 & 0.19 & 0.07 & 0.09 & 0.53 \\
\hline 11. Huaca Canal & 0.66 & 0.39 & 0.26 & 0.18 & 0.02 \\
\hline 12. Manyaraqui Canal & 2 & 0.5 & 1 & 0.21 & 0.07 \\
\hline
\end{tabular}

Table 7: Canal Specifications

There are several consistencies apparent in the design of the Inca canals. The Huaca Canal and the Manyaraqui Canal are modern, and the dimensions of these canals during Inca times are unknown. The other channels have similar features. The Bandolista Chute, Paqchapata Chute, and the Inca Diversion have steep slopes, at 50-60\%. The chutes were likely in place to dissipate energy, and the diversion was built to divert water into the Bandolista Canal. Looking at the remaining canals, there are some consistencies that could suggest design parameters for the construction of the canals. They have widths between 29 and $45 \mathrm{~cm}$, and over half of them are between 35 and $40 \mathrm{~cm}$. The hydraulic radius for these canals, which is a measure of flow efficiency, is between 9 and $13 \mathrm{~cm}$. The slopes are between $1 \%$ and $2 \%$, with only one exception. The similarities are interesting, and are possible design parameters for Inca canals.

The canal specifications in Table 7 were used to calculate flow rates with Equation 9, through each canal. For the canals, the value used for the depth of flow is the depth of the channel, $y$, except for the San Pablo Canal, Paqchapata Chute, Inca Diversion, Bandolista Chute, and the Manyaraqui Canal. For these canals, Equation 13 was used to calculate conjugate depths, which results in a downstream subcritical depth, which is before the hydraulic jump, and an upstream supercritical depth. The upstream supercritical depth was used as the maximum channel depth to calculate flow rates, because otherwise there would be spillage at hydraulic jumps. These calculations have to be done for these canals only, because the Froude Number is greater than 1. Those calculations are shown later. 


\begin{tabular}{|c|c|c|c|c|c|c|c|c|c|c|c|}
\hline & $\begin{array}{l}B_{w} \\
(m)\end{array}$ & $\begin{array}{l}\mathrm{d}_{1} \\
(\mathrm{~m})\end{array}$ & $\begin{array}{l}\mathrm{R}_{1} \\
(\mathrm{~m})\end{array}$ & $\begin{array}{l}\mathrm{S}_{0} \\
(\mathrm{~m} / \mathrm{m})\end{array}$ & $\begin{array}{l}\text { Q } \\
\left(\mathrm{m}^{3} / \mathrm{s}\right)\end{array}$ & $\begin{array}{l}\mathrm{V}_{1} \\
(\mathrm{~m} / \mathrm{s})\end{array}$ & $\mathrm{Fr}_{1}$ & $\begin{array}{l}\mathrm{d}_{2} \\
(\mathrm{~m})\end{array}$ & $\begin{array}{l}\text { Channel } \\
\text { depth (m) }\end{array}$ & $\begin{array}{l}\mathrm{V}_{2} \\
(\mathrm{~m} / \mathrm{s})\end{array}$ & $\mathrm{Fr}_{2}$ \\
\hline 1. San Pablo & 0.45 & 0.27 & 0.12 & 0.07 & 0.20 & 1.63 & 1.00 & 0.27 & 0.3 & 1.63 & 0.996 \\
\hline 3.PaqchapataChute & 2 & 0.17 & 0.145 & 0.5 & 1.66 & 4.89 & 3.78 & 0.83 & 1 & 1.00 & 0.352 \\
\hline 8. Inca Diversion & 0.4 & 0.05 & 0.040 & 0.6 & 0.05 & 2.59 & 3.70 & 0.24 & 0.25 & 0.54 & 0.357 \\
\hline 10. Bandolista Chute & 0.36 & 0.04 & 0.033 & 0.53 & 0.03 & 2.13 & 3.40 & 0.17 & 0.19 & 0.49 & 0.377 \\
\hline $\begin{array}{l}\text { 12. Manyaraqui } \\
\text { Canal }\end{array}$ & 2 & 0.26 & 0.206 & 0.07 & 1.37 & 2.64 & 1.65 & 0.49 & 0.5 & 1.40 & 0.636 \\
\hline
\end{tabular}

Table 8: Conjugate Depths

The water supply for the canals, with an exception of the Huaca Canal, is the mountain streams. The exact seasonal variability of the streams is unknown, but there is likely to be more flow in the summer and less in the winter. For this reason, I have done a sensitivity analysis for the canal capacities, at $100 \%$ full, $80 \%$ full, $50 \%$ full, and $30 \%$ full. This means the flow rate was calculated with the maximum channel depth $(y$ in Equation 9), then 0.8 times maximum channel depth, etc., this is not the same as $80 \%$ of the maximum flow. The results are in Table $9 \mathrm{in} \mathrm{m}^{3} / \mathrm{s}$, and Table $10 \mathrm{in} \mathrm{L/s.} \mathrm{Appendix} \mathrm{B}$ contains these flow rates in units of $\mathrm{L} / \mathrm{min}, \mathrm{ft}^{3} / \mathrm{s}$, and $\mathrm{gal} / \mathrm{min}$. 


\begin{tabular}{|c|c|c|c|c|}
\hline & $100 \%$ full & $80 \%$ full & $50 \%$ full & $30 \%$ full \\
\hline Canals & $\mathrm{Q}\left(\mathrm{m}^{3} / \mathrm{s}\right)$ & $\mathrm{Q}\left(\mathrm{m}^{3} / \mathrm{s}\right)$ & $\mathrm{Q}\left(\mathrm{m}^{3} / \mathrm{s}\right)$ & $\mathrm{Q}\left(\mathrm{m}^{3} / \mathrm{s}\right)$ \\
\hline 1. San Pablo & 0.20 & 0.15 & 0.08 & 0.04 \\
\hline 2. Musk'a Pujhio & 0.04 & 0.03 & 0.01 & 0.01 \\
\hline 3.PaqchapataChute & 1.66 & 1.17 & 0.55 & 0.27 \\
\hline 4. Lower Paqchapata & 0.10 & 0.07 & 0.04 & 0.02 \\
\hline 5. Media Luna & 0.07 & 0.05 & 0.03 & 0.01 \\
\hline 6. Pre-Inca & 0.09 & 0.07 & 0.04 & 0.02 \\
\hline 7. Inca Twin & 0.09 & 0.07 & 0.04 & 0.02 \\
\hline 8. Inca Diversion & 0.05 & 0.04 & 0.02 & 0.01 \\
\hline 9. Bandolista Canal & 0.07 & 0.06 & 0.03 & 0.02 \\
\hline 10. Bandolista Chute & 0.03 & 0.02 & 0.01 & 0.00 \\
\hline 11. Huaca Canal & 0.33 & 0.25 & 0.13 & 0.06 \\
\hline 12. Manyaraqui Canal & 1.37 & 0.97 & 0.46 & 0.20 \\
\hline
\end{tabular}

Table 9: Canal Capacities in $\left(\mathrm{m}^{3} / \mathrm{s}\right)$ 


\begin{tabular}{|l|r|r|r|r|}
\hline & $100 \%$ full & \multicolumn{1}{l|}{$80 \%$ full } & \multicolumn{1}{l|}{ ( $\%$ full } & \multicolumn{1}{l|}{ full } \\
\hline Canals & Q (gal/min) & Q (gal/min) & Q (gal/min) & Q (gal/min) \\
\hline 1. San Pablo & 3150 & 2340 & 1230 & 580 \\
\hline 2. Musk'a Pujhio & 580 & 440 & 240 & 110 \\
\hline 3.PaqchapataChute & 26300 & 18500 & 8720 & 4350 \\
\hline 4. Lower Paqchapata & 1520 & 1130 & 590 & 280 \\
\hline 5. Media Luna & 1070 & 800 & 420 & 200 \\
\hline 6. Pre-Inca & 1480 & 1100 & 580 & 280 \\
\hline 7. Inca Twin & 1480 & 1100 & 580 & 280 \\
\hline 8. Inca Diversion & 820 & 580 & 280 & 120 \\
\hline 9. Bandolista Canal & 1180 & 900 & 490 & 240 \\
\hline 10. Bandolista Chute & 490 & 340 & 160 & 70 \\
\hline 11. Huaca Canal & 5230 & 3890 & 2030 & 970 \\
\hline $\begin{array}{l}\text { 12. Manyaraqui } \\
\text { Canal }\end{array}$ & 21760 & 15400 & 7370 & 3170 \\
\hline
\end{tabular}

Table 10: Canal Capacities in gal $/ \mathrm{min}$

The water velocity of each canal is also calculated using Equation 10, and the values are recorded in Table 11. 


\begin{tabular}{|c|c|c|c|c|}
\hline & $100 \%$ full & $80 \%$ full & $50 \%$ full & $30 \%$ full \\
\hline Canals & $\mathrm{V}(\mathrm{m} / \mathrm{s})$ & $\mathrm{V}(\mathrm{m} / \mathrm{s})$ & $\mathrm{V}(\mathrm{m} / \mathrm{s})$ & $\mathrm{V}(\mathrm{m} / \mathrm{s})$ \\
\hline 1. San Pablo & 1.63 & 1.52 & 1.27 & 1.01 \\
\hline 2. Musk'a Pujhio & 0.51 & 0.48 & 0.41 & 0.33 \\
\hline 3.PaqchapataChute & 4.89 & 4.29 & 3.24 & 2.69 \\
\hline 4. Lower Paqchapata & 0.85 & 0.79 & 0.66 & 0.52 \\
\hline 5. Media Luna & 0.77 & 0.72 & 0.61 & 0.49 \\
\hline 6. Pre-Inca & 0.93 & 0.87 & 0.73 & 0.58 \\
\hline 7. Inca Twin & 0.93 & 0.87 & 0.73 & 0.58 \\
\hline 8. Inca Diversion & 2.59 & 2.29 & 1.75 & 1.28 \\
\hline 9. Bandolista Canal & 0.86 & 0.81 & 0.71 & 0.59 \\
\hline 10. Bandolista Chute & 2.13 & 1.88 & 1.43 & 1.04 \\
\hline 11. Huaca Canal & 1.28 & 1.19 & 1.00 & 0.79 \\
\hline 12. Manyaraqui Canal & 2.64 & 2.34 & 1.79 & 1.31 \\
\hline
\end{tabular}

\section{Table 11: Canal Velocities}

In order to use Equation 9, the Manning's Equation, it must be rough turbulent flow. Most open channels have rough turbulent flow, but to validate these flow rate estimates, the turbulence of the flow is verified. Turbulent flow can be identified by calculating Reynolds number for each canal, using Equation 11. The results are in Table 12 . 


\begin{tabular}{|c|c|c|c|c|}
\hline & $100 \%$ full & $80 \%$ full & $50 \%$ full & $30 \%$ full \\
\hline Canals & Re Number & Re Number & Re Number & Re Number \\
\hline 1. San Pablo & 200500 & 167500 & 107400 & 60100 \\
\hline 2. Musk'a Pujhio & 47100 & 40400 & 27400 & 16200 \\
\hline 3.PaqchapataChute & 710000 & 514000 & 253600 & 130400 \\
\hline 4. Lower Paqchapata & 101000 & 83800 & 52900 & 292003 \\
\hline 5. Media Luna & 80000 & 67200 & 44500 & 25800 \\
\hline 6. Pre-Inca & 104000 & 87100 & 56200 & 31700 \\
\hline 7. Inca Twin & 104000 & 87100 & 56200 & 31700 \\
\hline 8. Inca Diversion & 104000 & 76400 & 38900 & 17900 \\
\hline 9. Bandolista Canal & 84000 & 73600 & 52400 & 32700 \\
\hline 10. Bandolista Chute & 70000 & 51100 & 25700 & 11700 \\
\hline 11. Huaca Canal & 229000 & 191300 & 122200 & 68200 \\
\hline 12. Manyaraqui Canal & 545000 & 402900 & 205700 & 95000 \\
\hline
\end{tabular}

Table 12: Canal Reynolds's Numbers

A Reynolds number larger than 2000 indicates a turbulent flow, the values in Table 12 are much larger than 2000. This means that the flows in the canals are turbulent, and Manning's Equation is valid.

It seems clear that the Inca knew about hydraulic jumps and tractive force because their canals endured. Most Inca canals have a consistent gradual grade, and so the flow is slow, tranquil, and more manageable. Some of the steeper and larger canals have water moving through them pretty quickly. These canals are San Pablo Canal, Paqchapata Chute, Inca Diversion, Bandolista Chute, and the Manyaraqui Canal, the same canals that utilize hydraulic jumps, in this case the conjugate depths were calculated. Looking back at Table 11, one can see that the water is moving faster through these canals, as the water velocities in these canals are noticeably higher than the others. In a supercritical flow, the high energy levels are a result of the high velocities. The Froude Number is calculated with Equation 12, and the results are shown in Table 13. 


\begin{tabular}{|c|c|c|c|c|}
\hline & $100 \%$ full & $80 \%$ full & $50 \%$ full & $30 \%$ full \\
\hline Canals & Fr Number & Fr Number & Fr Number & Fr Number \\
\hline 1. San Pablo & 1.00 & 1.03 & 1.11 & 1.13 \\
\hline 2. Musk'a Pujhio & 0.33 & 0.35 & 0.38 & 0.40 \\
\hline 3.Paqchapata Chute & 3.78 & 3.72 & 3.54 & 3.80 \\
\hline 4. Lower Paqchapata & 0.54 & 0.56 & 0.59 & 0.61 \\
\hline 5. Media Luna & 0.49 & 0.51 & 0.55 & 0.57 \\
\hline 6. Pre-Inca & 0.60 & 0.62 & 0.66 & 0.68 \\
\hline 7. Inca Twin & 0.60 & 0.62 & 0.66 & 0.68 \\
\hline 8. Inca Diversion & 3.70 & 3.66 & 3.53 & 3.34 \\
\hline 9. Bandolista Canal & 0.50 & 0.53 & 0.59 & 0.63 \\
\hline 10. Bandolista Chute & 3.40 & 3.36 & 3.23 & 3.04 \\
\hline 11. Huaca Canal & 0.66 & 0.68 & 0.72 & 0.74 \\
\hline 12. Manyaraqui Canal & 1.65 & 1.64 & 1.58 & 1.50 \\
\hline
\end{tabular}

Table 13: Canal Froude Numbers

Table 13 proves that the Inca understood this concept of supercritical and subcritical flows. As previously mentioned, the Manyaraqui Canal is modern. It is known that the Inca had a canal somewhere in the same general area, but it was not this canal. Therefore, the only Inca canals that contained supercritical flow were San Pablo Canal, Paqchapata Chute, Inca Diversion, and Bandolista Chute. The San Pablo Canal is just barely supercritical, and this likely means that it had a consistent flow rate between $80 \%$ and $100 \%$ full. The Paqchapata Chute, Inca Diversion, and Bandolista Chute have slopes of $50 \%$ or greater, which means they are very steep. Hydraulic jumps were likely used in these canals, and the conjugate depths and subcritical Froude Numbers were shown previously in Table 8, while the ones reported in Table 13 are the supercritical Froude Numbers.

The canals in the Incamisana Watershed that are currently flowing have minimal sediment build-up, which suggests that they have the ability transport sediment. This was shown with Equations 14, 15, and 16 and the Shield's Diagram. The value for hydraulic radius, $R_{H}$, that was used to calculate shear velocity in Equation 15 is the hydraulic radius at $30 \%$ capacity, to be conservative. The parameters that were calculated were the particle Reynolds number, $R e_{*}$, the shear velocity, $V_{*}$, and the Shield's parameter. These values are shown in Table 14. 


\begin{tabular}{|l|r|r|r|}
\hline Canals & \multicolumn{1}{|l|}{$V^{*}(\mathrm{~m} / \mathrm{s})$} & \multicolumn{1}{|l|}{$e^{*}$} & \\
\hline 1. San Pablo & 0.20 & 202 & 2.60 \\
\hline 2. Musk'a Pujhio & 0.07 & 69 & 0.30 \\
\hline 3.Paqchapata Chute & 0.48 & 478 & 14.54 \\
\hline 4. Lower Paqchapata & 0.11 & 105 & 0.70 \\
\hline 5. Media Luna & 0.09 & 88 & 0.49 \\
\hline 6. Pre-Inca & 0.10 & 103 & 0.68 \\
\hline 7. Inca Twin & 0.10 & 103 & 0.68 \\
\hline 8. Inca Diversion & 0.28 & 278 & 4.92 \\
\hline 9. Bandolista Canal & 0.10 & 104 & 0.69 \\
\hline 10. Bandolista Chute & 0.24 & 236 & 3.55 \\
\hline 11. Huaca Canal & 0.13 & 130 & 1.08 \\
\hline 12. Manyaraqui Canal & 0.22 & 223 & 3.16 \\
\hline
\end{tabular}

Table 14: Particle Reynolds Number, Shear Velocity, and Shield's Parameter

The Shield's parameter and particle Reynolds number are then plotted on the Shield's Diagram on Figure 28. The particle Reynolds number is on the X-axis, and the Shield's parameter is on the y-axis, the point on the graph where the two values meet, in relation to the line on the diagram determines whether there is sediment movement or not. 


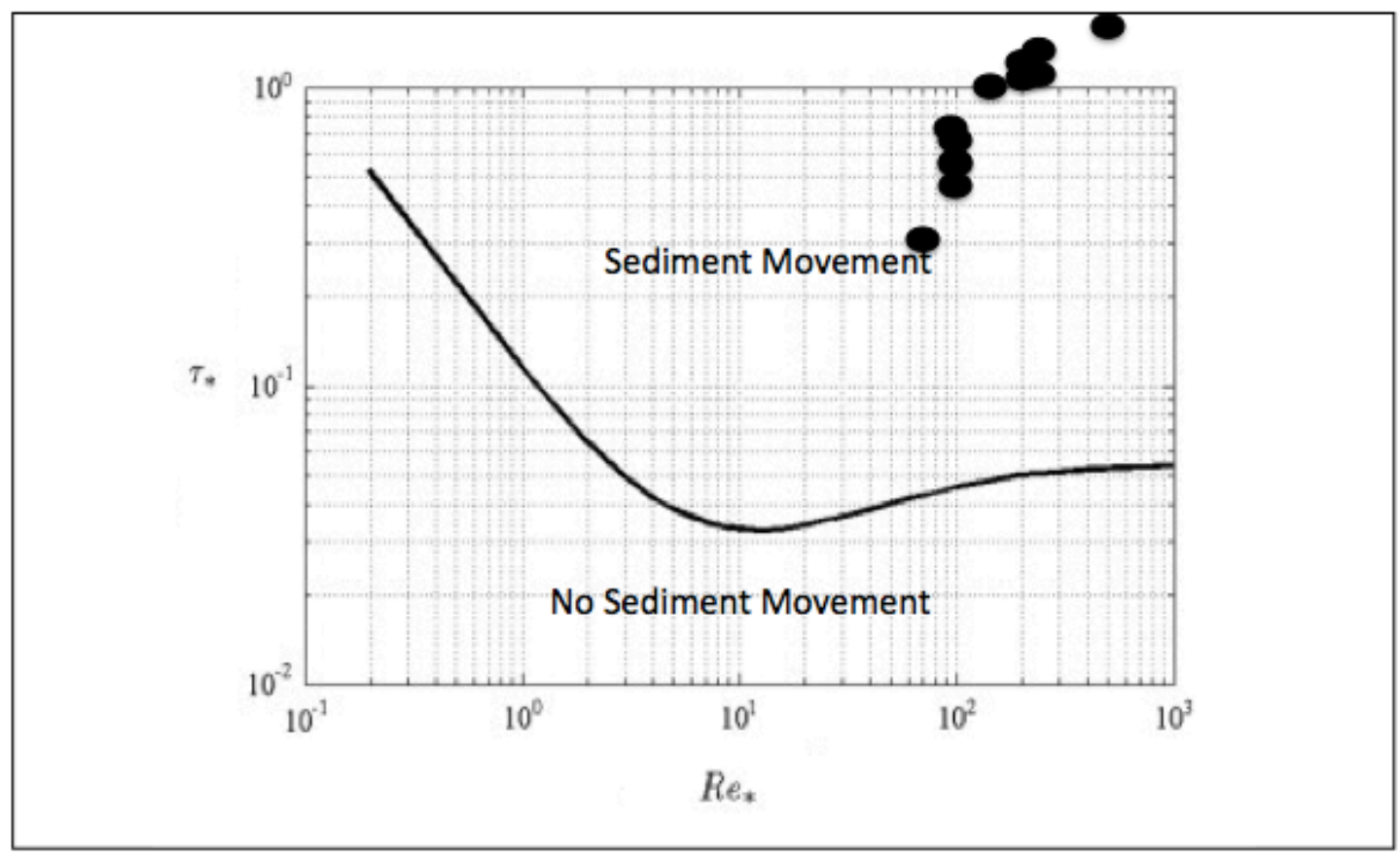

Figure 28. Shield's Diagram for Sediment in Water With Data. Illustrates Relationship Between Sediment Movement, Particle Reynolds Number, and Shield's Parameter. Adapted from The Hydraulics of Open Channel Flow by H. Chansen, 1999. John Wiley \& Sons.

Figure 28 shows that all of the mountain canals allow for particle movement. Sediment build-up is minimized. This suggests that the Inca designed the mountain canal system in a way that requires minimal maintenance and optimal efficiency.

\section{Agricultural Terraces}

There are agricultural terraces along the river up the entire valley. The major terrace complexes are mapped on Figure 29, the Terrace Map. These are not the only terraces in the valley, but they are ones that were observed in the field, and that correspond to the canals that were analyzed. 


\section{Mountain Terraces}

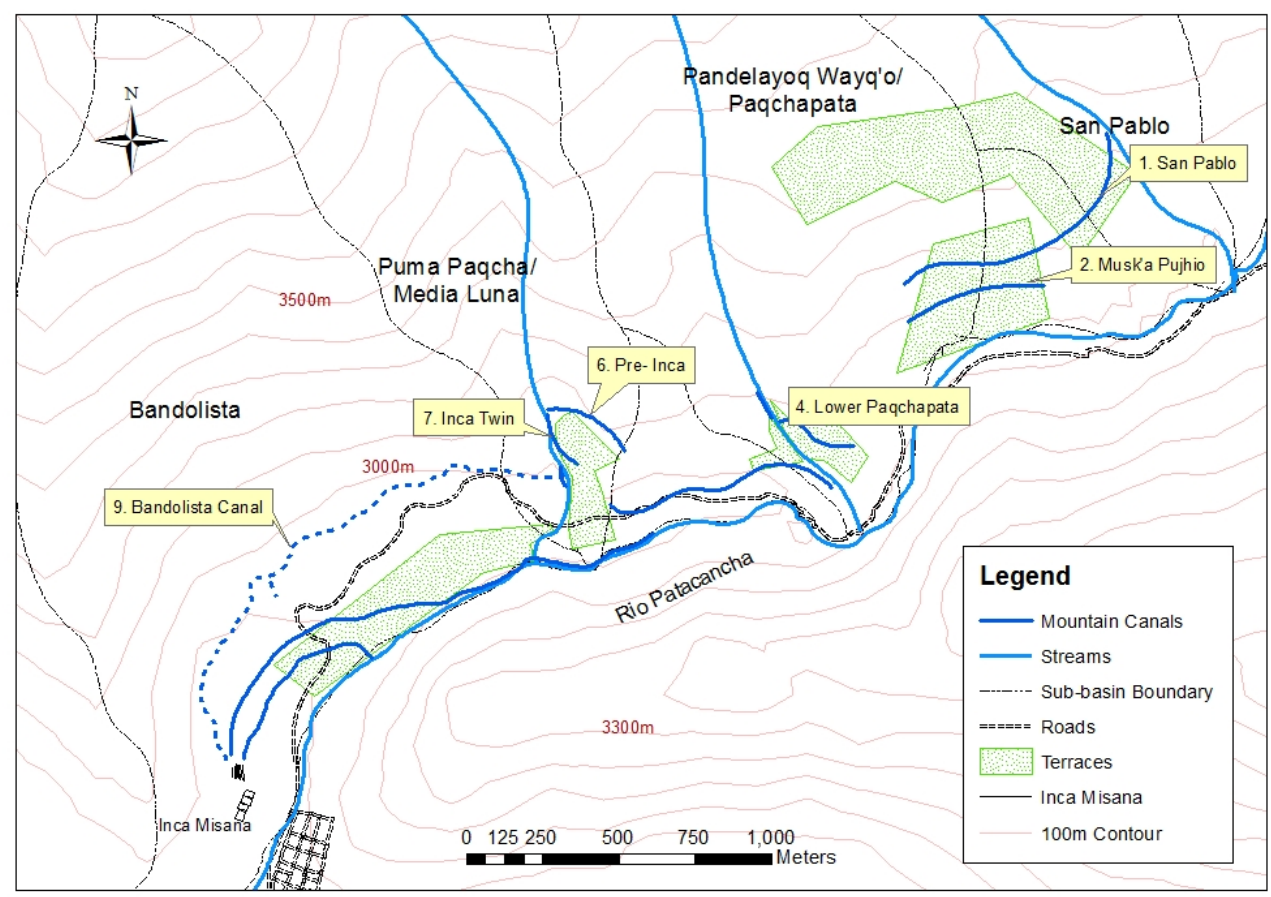

Figure 29. Terrace Map. Map of the Terraces Investigated in the Study.

The major crop grown on the terraces at Ollantaytambo was corn, and the daily evapotranspiration rates are shown in Table 15. The depth of water needed for corn to grow is different in different temperatures and in different stages of growth. 


\begin{tabular}{|c|c|c|c|c|}
\hline & $16^{\circ}-20^{\circ} \mathrm{C}$ & $21^{\circ}-26^{\circ} \mathrm{C}$ & $60^{\circ}-69^{\circ} \mathrm{F}$ & $70^{\circ}-79^{\circ} \mathrm{F}$ \\
\hline Week & $\begin{array}{l}\text { Water Use } \\
\text { (mm/day) }\end{array}$ & $\begin{array}{l}\text { Water Use } \\
\text { (mm/day) }\end{array}$ & $\begin{array}{l}\text { Water Use } \\
\text { (in/day) }\end{array}$ & $\begin{array}{l}\text { Water Use } \\
\text { (in/day) }\end{array}$ \\
\hline 1 & 0.51 & 0.76 & 0.02 & 0.03 \\
\hline 2 & 0.76 & 1.02 & 0.03 & 0.04 \\
\hline 3 & 1.02 & 1.27 & 0.04 & 0.05 \\
\hline 4 & 1.52 & 1.78 & 0.06 & 0.07 \\
\hline 5 & 2.01 & 2.54 & 0.08 & 0.1 \\
\hline 6 & 2.29 & 3.05 & 0.09 & 0.12 \\
\hline 7 & 2.79 & 3.81 & 0.11 & 0.15 \\
\hline 8 & 3.05 & 4.06 & 0.12 & 0.16 \\
\hline 9 & 3.30 & 4.32 & 0.13 & 0.17 \\
\hline 10 & 3.80 & 4.83 & 0.15 & 0.19 \\
\hline 11 & 3.56 & 4.83 & 0.14 & 0.19 \\
\hline 12 & 3.56 & 4.57 & 0.14 & 0.18 \\
\hline 13 & 3.30 & 4.32 & 0.13 & 0.17 \\
\hline 14 & 2.80 & 3.56 & 0.11 & 0.14 \\
\hline 15 & 2.29 & 2.79 & 0.09 & 0.11 \\
\hline 16 & 1.78 & 2.29 & 0.07 & 0.09 \\
\hline 17 & 1.52 & 1.78 & 0.06 & 0.07 \\
\hline 18 & 1.02 & 1.27 & 0.04 & 0.05 \\
\hline
\end{tabular}

Table 15: Corn Crop Demand Data for Various Temperatures. Full Potential of Daily ET By Week. Adapted from "Irrigation Scheduling"," by J. Wright, 1989, University of Minnesota Extension Service Bulletin FO-03875.

The growing season in South America is usually 9 months long, from September until April, and there are usually two or three cycles of crops (Cordonnier, 2011). The average daily rainfall was calculated for each month using average monthly rainfall and dividing by the number of days in each month. The water demand was estimated using evapotranspiration data in Table 15 and the typical corn season, and the results are shown in Table 16. 


\begin{tabular}{|l|r|r|}
\hline Month & $\begin{array}{l}\text { Daily Rainfall } \\
\text { (mm/day })\end{array}$ & $\begin{array}{l}\text { Water Demand } \\
(\mathrm{mm} / \text { day })\end{array}$ \\
\hline Jan & 4.9 & 4.8 \\
\hline Feb & 4.0 & 2.3 \\
\hline Mar & 3.1 & 1.2 \\
\hline Apr & 1.2 & 0 \\
\hline May & 0.2 & 0 \\
\hline Jun & 0.1 & 0 \\
\hline Jul & 0.1 & 1.8 \\
\hline Aug & 0.2 & 4.3 \\
\hline Sep & 0.7 & 4.8 \\
\hline Oct & 1.5 & 4.3 \\
\hline Nov & 2.3 & 0 \\
\hline Dec & 3.5 & 0 \\
\hline
\end{tabular}

Table 16: Daily Rainfall and Daily Agricultural Demand

The values in Table 16 show that the rainfall in Ollantaytambo was not adequate to sustain the crops under natural conditions. The irrigation canals would have been necessary for the Inca to grow corn on the terraces for the growing season that lasted from September until April.

The area of terraces in each sub-basin was calculated, and is shown in Table 17.

\begin{tabular}{|l|r|}
\hline Sub-Basin & $\begin{array}{l}\text { Area of Terraces } \\
\left(\mathrm{m}^{2}\right)\end{array}$ \\
\hline Bandolista & 61600 \\
\hline Puma Paqcha & 26800 \\
\hline Intermediate1 & 6000 \\
\hline Pandelayoq Wayq'o & 50800 \\
\hline Intermediate 2 & 46000 \\
\hline San Pablo & 24900 \\
\hline Intermediate 3 & 10600 \\
\hline Yuracmayo & 45680 \\
\hline
\end{tabular}

Table 17: Area of Terraces by Sub-Basin 
The data in Tables 14 and 15 were used to compute the water demand of the agricultural terraces. In this case, evapotranspiration is assumed to be the water demand. In reality, there may be other factors that would affect the overall water demand, but it would not change the results of the analysis. The daily crop demands in Table 14 were multiplied by the area of terraces in Table 15, to determine a water demand per day in each basin in each of these circumstances in each sub-basin. Figure 27 shows the locations of the main agricultural terraces.

Then, for each basin, a minimum demand, maximum demand, and the average demand were calculated, and can be seen in Table 18. For these calculations, water demand is assumed to be the gross evapotranspiration. The minimum demand is at low temperatures, between 16 and $20^{\circ} \mathrm{C}$, in the first week of growing, while the maximum demand is in warmer temperatures, between 21 and $26^{\circ} \mathrm{C}$, in the 10 th week of growing.

\begin{tabular}{|c|c|c|c|}
\hline Sub-Basin & $\begin{array}{c}\text { Min Demand } \\
{\left[\text { Week } 1,16^{\circ}-20^{\circ} \mathrm{C}\right]} \\
\left(\mathrm{m}^{3} / \text { day }\right)\end{array}$ & $\begin{array}{c}\text { Max Demand } \\
{\left[\text { Week } 10,21^{\circ}-26^{\circ} \mathrm{C}\right]} \\
\left(\mathrm{m}^{3} / \text { day }\right)\end{array}$ & $\begin{array}{c}\text { Average Demand } \\
\text { [Average demand for all } \\
\text { weeks, } 16^{\circ}-26^{\circ} \mathrm{C} \text { ] }\left(\mathrm{m}^{3} / \text { day }\right)\end{array}$ \\
\hline Bandolista & 31 & 297 & 160 \\
\hline Puma Paqcha & 14 & 129 & 70 \\
\hline Intermediate 1 & 3 & 29 & 16 \\
\hline $\begin{array}{l}\text { Pandelayoq } \\
\text { Wayq'o }\end{array}$ & 26 & 245 & 132 \\
\hline Intermediate 2 & 23 & 222 & 120 \\
\hline San Pablo & 13 & 120 & 65 \\
\hline Intermediate 3 & 5 & 51 & 28 \\
\hline Yuracmayo & 23 & 220 & 119 \\
\hline Total Demand & 138 & 1313 & 710 \\
\hline
\end{tabular}

Table 18: Water Demand of the Terraces

As can be see in the map in Figure 29, there are 6 canals that were likely used for irrigation. These canals are San Pablo, Musk'a Pujhio, Lower Patacancha, Pre-Inca, Inca Twin, and Bandolista, the capacities of these canals are reported in Table 19. 


\begin{tabular}{|c|c|c|c|c|}
\hline & $100 \%$ full & $80 \%$ full & $50 \%$ full & $30 \%$ full \\
\hline Canals & $\mathrm{Q}\left(\mathrm{m}^{3} /\right.$ day $)$ & $\mathrm{Q}\left(\mathrm{m}^{3} /\right.$ day $)$ & $\mathrm{Q}\left(\mathrm{m}^{3} /\right.$ day $)$ & $\mathrm{Q}\left(\mathrm{m}^{3} /\right.$ day $)$ \\
\hline 1. San Pablo & 17100 & 12800 & 6700 & 3200 \\
\hline 2. Musk'a Pujhio & 3200 & 2400 & 1300 & 620 \\
\hline $\begin{array}{l}\text { 4. Lower } \\
\text { Paqchapata }\end{array}$ & 8300 & 6200 & 3200 & 1500 \\
\hline 6. Pre-Inca & 8100 & 6000 & 3200 & 1500 \\
\hline 7. Inca Twin & 8100 & 6000 & 3200 & 1500 \\
\hline 9. Bandolista & 6400 & 4900 & 2700 & 1300 \\
\hline Total Capacity & 51200 & 38300 & 20300 & 9620 \\
\hline
\end{tabular}

Table 19: Canal Capacity $\mathrm{m}^{3} /$ day

A lot can be read from Tables 17 and Table 18. From solely comparing the totals, even at $30 \%$ full, the canals contain over 7 times the total water demand of the terraces. This indicates that there is more than adequate infrastructure to sustain the agricultural terraces. The San Pablo and Musk'a Pujhio canals serve the terraces in the San Pablo, Intermediate 2, and Pandelayoq Wayq'o Basins. The sum of the maximum evapotranspiration in those basins was estimated to be $590 \mathrm{~m}^{3} /$ day, and the San Pablo Canal, at $30 \%$ full discharged $3200 \mathrm{~m}^{3} /$ day, while the Musk'a Pujhio discharged at 620 $\mathrm{m}^{3} /$ day, these canals are adequate. The Lower Paqchapata supplied the Pandelayoq Wayq'o Basin only, which has a maximum demand of $245 \mathrm{~m}^{3} /$ day, and the Lower Paqchapata discharges at $1500 \mathrm{~m}^{3} /$ day at $30 \%$ full, so this is adequate. The Pre-Inca and Ina Twin Canals serve the terraces in the Puma Paqcha Basin, which have a maximum demand of $129 \mathrm{~m}^{3} /$ day, while these canals each discharge $1500 \mathrm{~m}^{3} /$ day at $30 \%$ full, meaning this canal is adequate. Finally, the Bandolista Canal services the Bandolista Basin terraces, that demand $297 \mathrm{~m}^{3} /$ day, while the Bandolista Canal discharges 1300 $\mathrm{m}^{3} /$ day at $30 \%$ full, meaning this canal is also adequate.

It seems clear that that even at $30 \%$ full, the canals have ample capacity to supply the crops at the maximum demand. This is important since rainfall alone in this area could not sustain all the crops. A comparison of Table 4, Rainfall Data, and Table 15, Corn Crop Demand shows that rainfall is not adequate to sustain the terraces. In both the wet and dry season seasons, there is more water demanded from the crops than rainfall. This justifies the pre-Inca and Inca people building this canal system, and how much water they could each carry.

The Bandolista Canal is the one that has been identified as a second possible source to the Incamisana. The stone-carved Bifurcation point allows $7 \mathrm{~L} / \mathrm{s}$, or $111 \mathrm{gal} / \mathrm{min}$ through the channel. If a $10 \%$ loss per $1 \mathrm{~km}$ is assumed, that means at least $8.05 \mathrm{~L} / \mathrm{s}$, or $128 \mathrm{gal} / \mathrm{min}$ is needed from the Bandolista Canal, and the capacity of the Bandolista 
Canal, at $30 \%$ full is about $15 \mathrm{~L} / \mathrm{s}$. The excess water in the Bandolista Canal, which was the other $7 \mathrm{~L} / \mathrm{s}$, or $604 \mathrm{~m}^{3} /$ day would have been available to irrigate the agricultural terraces in the Bandolista sector, that have a maximum demand of $297 \mathrm{~m}^{3} / \mathrm{day}$. This means the Bandolista Canal alone was able to supply the maximum amount of water to the Incamisana and irrigate the terraces at the time.

This is evidence that the Inca may have intended for the Bandolista Canal to supply the Incamisana, whether it ever actually did or not is unknown. What is apparent, is that it had sufficient capacity to serve as a single source of the Incamisana and that the Bandolista Canal pre-dated the Incamisana. It is likely that that the canal was there and functioning when the Inca arrived to Ollantaytambo, and they built the Incamisana where it is because of the location of the canal.

The canals that were not used for irrigation had other purposes. The Paqchapata Chute, which is what the Pandelayoq Wayq'o stream turns into before it reaches the Rio Patacancha. The Paqchapata Chute was likely constructed to dissipate energy and to provide adequate water to the canals it feeds, which are the Media Luna and the Lower Paqchapata. Although there were no terraces observed around the Media Luna Canal, it is still possible that there were terraces at one point in time that it may have fed. Ultimately, the purpose of the Media Luna Canal is unknown, but there is evidence that it ends before it reaches the Puma Paqcha, or Media Luna Stream. The Inca Diversion was only constructed to divert water from the Puma Paqcha into the Bandolista Canal. The purpose of the Bandolista Chute is unknown, although it may have been a diversion or a spillway. The Huaca Canal was and still is used for irrigation, but it is unknown which parts are Inca and which parts are modern, so it was removed it from the irrigation analysis altogether, and there is still an adequate amount of water directed to the terraces to support the crops. The Manyaraqui Canal is modern, so its purpose is not relevant in this analysis.

\section{Conclusion}

The Huaca Canal currently provides water to the Incamisana, and it likely did originally. It is located at the perfect grade, and the path from the Huaca Canal to the Bifurcation Point at the entrance of the Incamisana is beautiful, and there is evidence of this being the source of the Incamisana. The evidence includes the cut notch in Terrace Three, which is set perfectly to handle the flow from the Huaca Canal.

The Bandolista Canal may have provided water to the Incamisana. The only mountainside source for the Bandolista Canal is the Quebrada Puma Paqcha, locally referred to as the Media Luna Stream. This was the only mountain stream that could have supplied that Incamisana. The source for the Bandolista Canal, hence a likely source for the Incamisana is the Puma Paqcha Stream. It is not clear whether the Inca operated this Kilke canal or not, but if they did, it was able to supply the water to the Incamisana and irrigate the agricultural terraces.

The Incamisana Watershed contains remarkable Inca engineering. The Incamisana itself is an unbelievable masterpiece of hydraulic engineering, but there is evidence of their true genius throughout the valley. The Inca were successful at making a 
mountain valley in arid climate water-rich with plentiful water sources throughout the entire valley.

The canals have some consistencies in their design. Almost all of the canals have a 1 to $2 \%$ slope, which helped to control the flow, and likely made it easier for the Inca to stabilize the mountain. The widths of the mountain canals are between 30 to $45 \mathrm{~cm}$, or 12 to 18 inches, and the hydraulic radii are between 9 and $13 \mathrm{~cm}$, or 3.5 to 5 inches. This seems to be the typical design criteria for the ancient canals in the Incamisana Watershed. There are two constructed chutes in the area, the Paqchapata Chute and the Bandolista Chute. Both of these chutes have a 50\% slope and utilized hydraulic jumps. The flow in the canals are characterized as subcritical, with the exception of the canals that utilize hydraulic jumps, in which case the energy is dissipated to prevent supercritical flow for an extended length. These trends suggest that there was some cohesiveness in the construction of the channels and they were not independent projects.

It is common to find agricultural terraces located directly downhill of the canals. This was done for irrigation purposes, as water must run downhill from the canals to the terraces. The terraces also serve to stabilize the mountain, as this is an active mountain with evidence of many landslides. The irrigation canals have a capacity to carry 5 million gal/day at $50 \%$ full, while the average water demand of the agricultural terraces was about 190,000 gal/day. At 50\% capacity, there would have been over 4.5 million gal/day for domestic water or other uses.

The entire Incamisana Watershed was carefully and strategically planned. The canal system was both aesthetic and functional. The canals were built to last, and many of them did. The Incas understood hydraulics and the basic engineering principles explained in this paper. Of course they did not know the equations that engineers do today, but they understood that a continuous, gradual slope in a canal creates a flow that is easy to manage and prevent erosion. They also understood that hydraulic jumps dissipated energy and prevented erosion. They also understood that low-impact development is the most sustainable in the long run. The ability of the canals to allow for sediment movement means that these canals were dependable and the flows were not slowed by the build-up of sediment.

The Inca practiced low-impact development, a concept today's engineers struggle with. The Inca knew it was important to utilize the mountain streams because they were the only reliable sources of water on the mountain. The mountain streams were fed from runoff, springs, and groundwater. In the city, the Rio Patacancha was a reliable domestic water supply; this was fed from runoff, springs, groundwater, and glacier water. Rainfall was not adequate for agricultural purposes, and utilizing the stream and river water was vital for the communities that resided in Ollantaytambo. 


\section{References}

Chanson, H. (1999). The Hydraulics of Open Channel Flow. John Wiley \& Sons. New York, NY.

Coghlan, A. (2009). Clearnig Oasis Trees Felled Ancient Peru Civilization. Latin American Antiquity, Vol 20, p 303.

Cordonnier, M. (2011). Argentina Month-By Month Crop Cycles. Soybean and Corn Advisor. Found at http://www.soybeansandcorn.com/Argentina-Crop-Cycles.

Lindeburg, M. (2003). Civil Engineering Reference Manual for the PE Exam. Belmont, CA. Professional Publications.

Luzar, J. (2007). The Political Ecology of a "Forest Transition": Eucalyptus forestry in the Southern Peruvian Andes. Ethnobotany Research and Applications. Gainsville, FL.

MacQuarrie, K. (2007). Last Days of the Incas. Simon \& Schuster. New York, NY.

Mays, L. (2011). Water Resources Engineering. John Wiley \& Sons. Hoboken, NJ.

National Research Council Staff. (1989). Lost Crops of the Incas: Little-Known Plants of the Andes with Promise for Worldwide Cultivation. Washington, DC: National Academies Press.

Niles, S. (1987). Callachaca: Style and Status in an Inca Community. University of Iowa Press. Iowa City, IA.

Pumayalli, R. (2008). Watershed Modeling by Remote Sensing and AGWA-SWAT for Western Portion of Cusco Watershed-Peru.

United States Department of Agriculture. (June 1986). Urban Hydrology for Small Watersheds TR-55. [Table 2].

Wildfire, L., Miksad, R., Rosa, A., Culotti, A., Beckman E., Vranich, A., Wright, K. (2011). A Paleo-Hydrologic Analysis of a Rainfall-Runoff and Drainage of the Incan Ruins of Saqsaywaman.

Williams, S.J., Arsenault, M.A., Buczkowski, B.J., Reid, J.A., Flocks, J., Kulp, M.A., Penland, S., and Jenkins, C.J. (2006). Surficial sediment character of the Louisiana offshore Continental Shelf region: a GIS Compilation. U.S. Geological Survey Open-File Report 2006-1195, online at http://pubs.usgs.gov/of/2006/1195/index.htm.

Woodward, D., Hawkins, R., Hjelmfelt, A., Mullem, V., and Quan, Q. (1998) Curve Number Method: Origins, Applications, and Limitations. Derwood, MD. USDA. 
Wright, J. (1989). Irrigation Scheduling. University of Minnesota Extension Service Bulletin FO-03875.

Wright, K., and Zegarra, V. (2000). Machu Picchu: A Civil Engineering Marvel. Reston, VA. American Society of Civil Engineers.

Wright, K. (2006). Tipon: Water Engineering Masterpiece of the Inca Empire. Reston, VA. American Society of Civil Engineers.

Wright, K., Wright, R., Zegarra, A., and McEwan, G. (2011). Moray: Inca Engineering Mystery. Reston, VA. American Society of Civil Engineers.

Wurbs, R. and James, W. (2002). Water Resources Engineering. Prentice Hall. Upper Saddle River, NJ. 


\section{Appendix A}

The general method used for modeling the watershed in Arc GIS 10 is shown in the figure below. This model was created using Arc GIS's ModelBuilder feature by Jenna Sollner, and can be used to delineate sub-basins at other sites. The model was adapted from the technique outlined in Pumayalli's paper (2008).

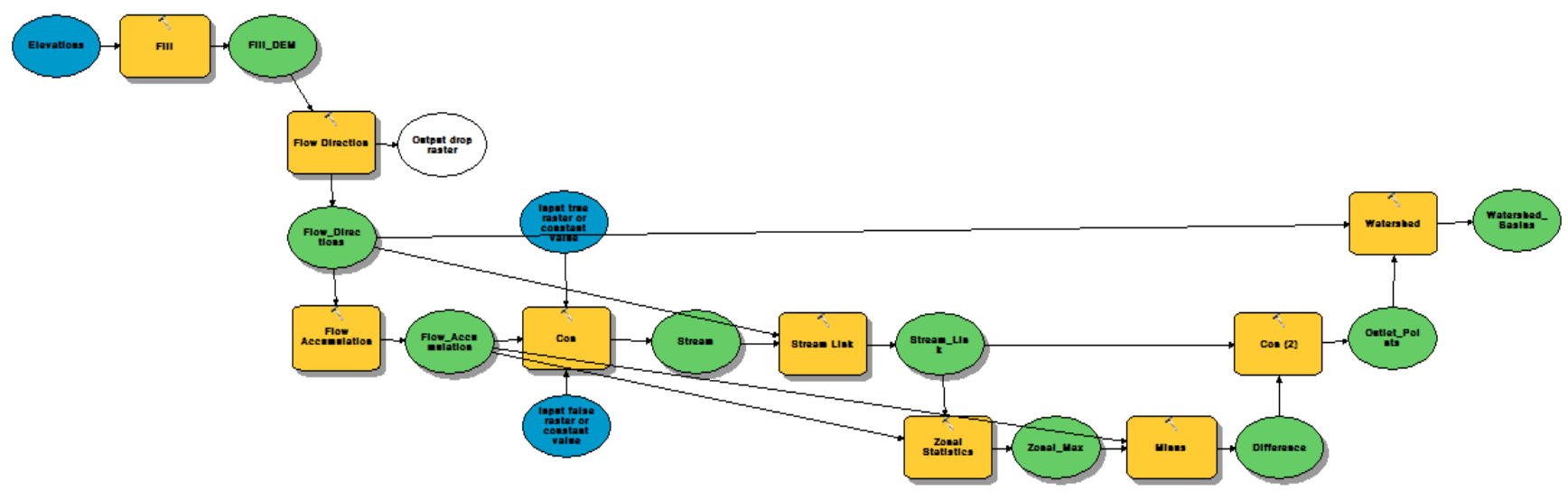

\section{Arc GIS ModelBuilder Model of watershed delineation}

Watershed modeling using GIS is relatively simple if you are even a little familiar with ArcGIS, I will outline the basic steps involved in creating a watershed map and delineating the drainage basins.

The Ministry of Economy, Trade and Industry of Japan (METI) and the National Aeronautics and Space Administration (NASA) Advanced Spaceborne Thermal Emission and Reflection Radiometer (ASTER) Global Digital Elevation Model Version 2 (GDEM V2) on October 17, 2011, which gives $30 \mathrm{~m}$ by $30 \mathrm{~m}$ resolution digital elevation models (DEMs). It can be found at http://www.jspacesystems.or.jp/ersdac/GDEM/E/index.html. You can download the entire global data set, or choose an area that you want the data for.

For Ollantaytambo, Peru, a block of data surrounding the location was downloaded, then the "Clip" feature was used in ArcGIS to get rid of excess data, and focus on the area of interest. For this case, I wanted to model the land from the Incamisana up to the Yuracmayo, and the sub-basins in between. Once you define your scope, use "Clip" for the excess data, it will not be needed. In order to do a watershed 
analysis, you will want to preserve area in your projection. This is done when importing the data set into your ArcGIS file; when it asks you what projection to use, choose one that is equal area. For the example in Peru, Albers Equal Area Projection for South America was used.

The next step is to use the "Conversion Tools" Toolbar to convert the DEM to a GRID raster in. This GRID raster can be interpolated using the Spatial Analyst Tool, which includes the Hydrology Tool in the Arc toolbox. The area covered by the DEM was more than what was needed for this problem, so the Clip feature was used to cut the excess data out, the piece of land used for the model was approximately 10 miles by 15 miles. The DEM should look something like the figure below.

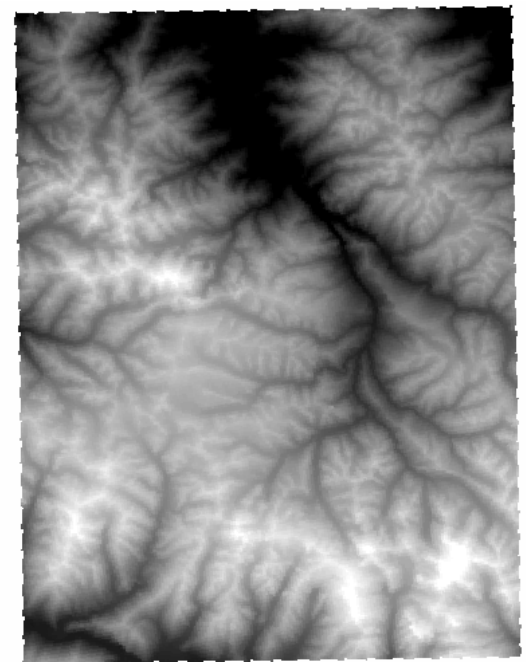

\section{DEM file}

From the elevation data, using the Spatial Analyst, a contour map of the study area can be created. To do this, first make sure the Spatial Analyst Toolbar is turned on. Under the View - Toolbar menu activate the Spatial Analyst Toolbar. Under the Tools Extension menu verify that the Spatial Analyst extension is activated. Now, on the Arc Toolbox, expand the Surface menu, then click contour (ArcToolbox $>$ Spatial Analyst $>$ 
Surface $>$ Contour). You will see the window below:

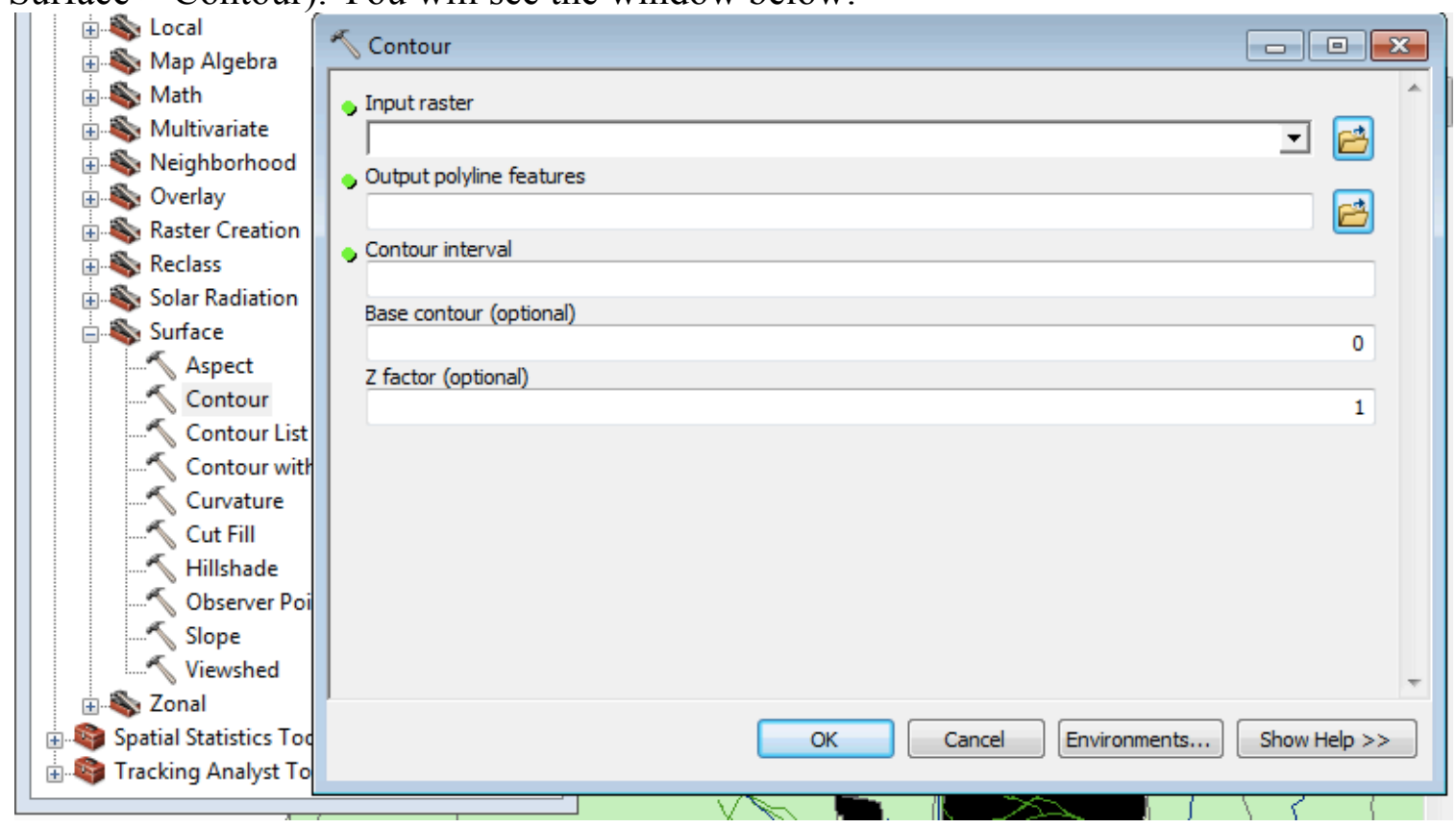

\section{Contour Dialog Box}

The input raster is the DEM file, and the output file will be what you want to name the contour layer. The contour interval is how many meters you would like between each contour. When you click OK, a contour layer will be created, similar to the one below, and drawn on the map, you can now turn this layer off and on as needed.

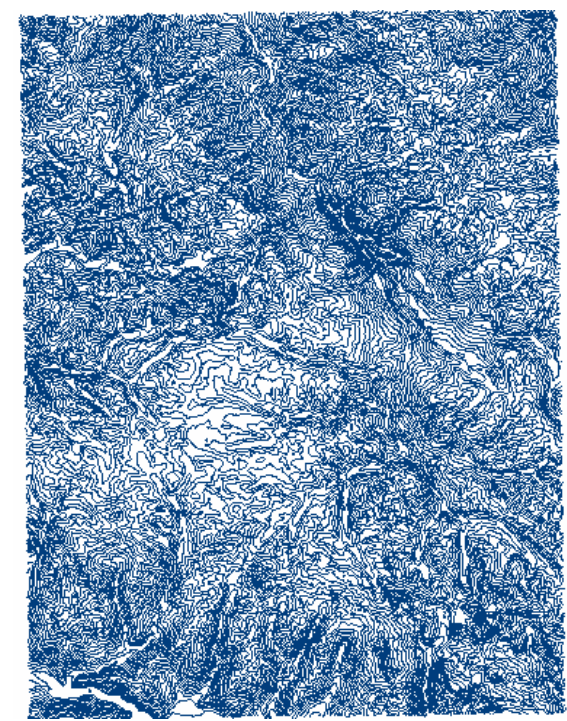

\section{Contour Map}

Another tool was used to fill pits in the raster that would otherwise cause errors in the analysis (ArcToolbox $>$ Spatial Analyst $>$ Hydrology $>$ Fill). You will see a window similar to the one for creating contours, again the input is the elevation DEM, and the output will be your "filled" DEM. This raster looks almost exactly like the elevation 
layer, but it is now prepared for hydrologic modeling. The next step is to create a flow model for the watershed, which shows which way water will flow if it lands at any location in the watershed area (ArcToolbox $>$ Spatial Analyst $>$ Hydrology $>$ Flow Direction). The input for the flow direction raster must be the "filled" DEM. The flow direction raster created will automatically assign a color to each flow direction. You can see a sample Flow Direction Raster below.

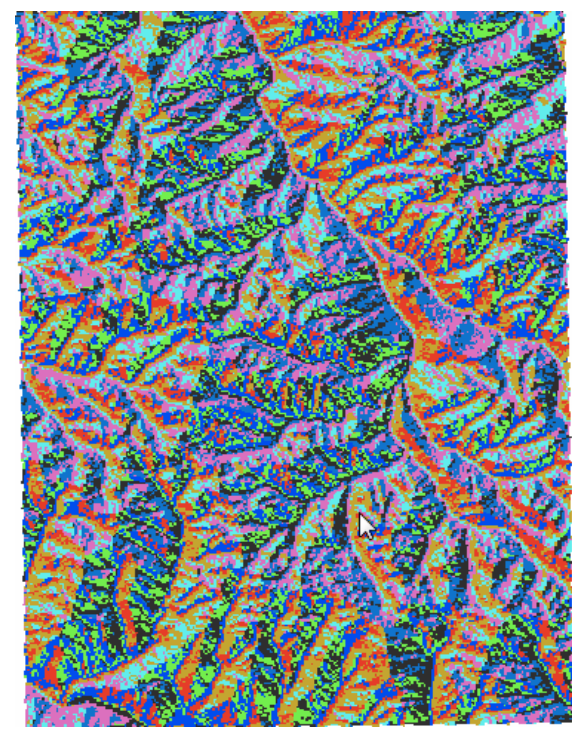

\section{Flow Direction Raster}

It will assign a number to each flow direction: 1-East, 2-Southeast, 4-South, 8Southwest, 16-West, 32-Northwest, 64-North, and 128- Northeast. It is helpful to assign these directions as the labels for each color. You can do this by right clicking on the Flow Direction raster on the Table of Contents on the left side of the screen, and click Properties, then select the Symbology tab, and change the labels there.

Next, use the Flow Accumulation tool, to differentiate upstream from downstream (ArcToolbox $>$ Spatial Analyst $>$ Hydrology $>$ Flow Accumulation). The input for flow accumulation is the flow direction raster. The flow accumulation grid shows the number of cells that flow into each cell. This grid shows the downhill accumulation of water into the streams. An example of this raster is shown below. 


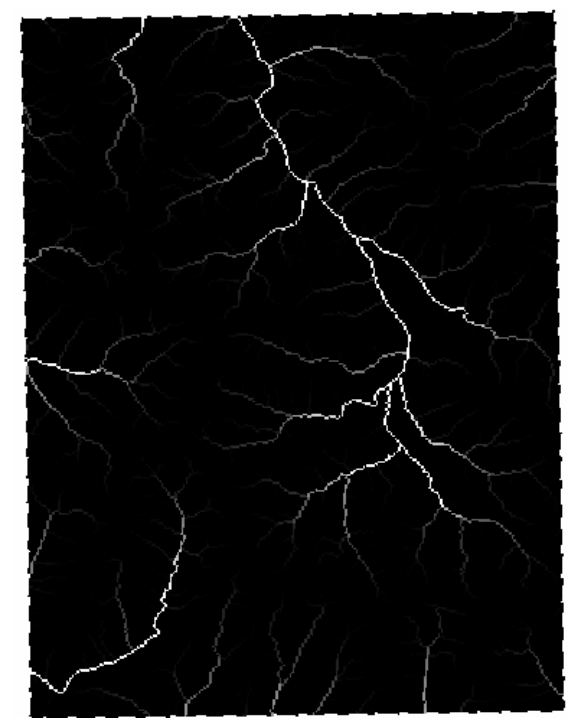

\section{Flow Accumulation}

The area around the streams is shown as darker cells, and the streams have higher values and are white, since there are varying values of accumulation and flow. Make sure the result agrees with the topography and location of known streams, do this by verifying the location of streams by adding a basemap to your file, or just looking at a Google Maps Aerial and making sure the location of streams is reasonable.

The streams can be defined from the result of flow accumulation. The value for a stream pixel can be determined by calculating the number of grid cells there are in the file, and any cell with a number higher than that would be defined as a stream. This can be done by knowing the area of your DEM, and dividing by the cell size, which is $30 \mathrm{~m}$ by $30 \mathrm{~m}$. The raster calculator will create this layer. To access the raster calculator, click the "Search" tab on the left side of the screen. Type "raster calculator" into the search bar, and click the first option that shows up. Next, type the expression as a conditional statement: "Con("(FlowAccumulation">\# of cells in grid,1)", click OK. You have now created a stream layer. The stream raster can then be created (ArcToolbox $>$ Spatial Analyst $>$ Hydrology $>$ Stream to Feature). The stream network can be derived from the flow directions and stream raster (ArcToolbox $>$ Spatial Analyst $>$ Hydrology $>$ Stream Link). The stream link layer will look something like the figure below. 


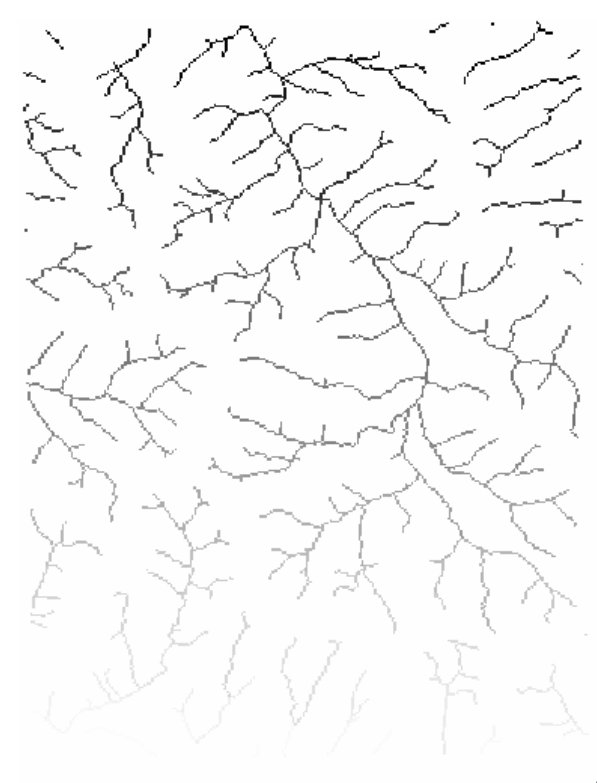

\section{Stream Feature Layer}

The pour points or outlets for the streams are then determined by identifying the maximum values of flow accumulation. Again, open the Raster Calculator, and type the expression "Zonal Statistics("StreamNetwork", "Value", "FlowAccumulation", "Maximum" ). Make sure there is a space after each comma, and you use the quotation marks. Also, the "StreamNetwork" and "FlowAccumulation" is the name of the layer. For example, if the Flow Accumulation layer is named something different, then that name needs to be the text within the quotation marks. The output for this layer should be ZonalMax. The raster calculator will needed once more, to define the outlet points. Type the expression: Con("ZonalMax"=="Flow_Accu","Streams_Network"), and make the output data set "OutletPoints."

You have now created many layers of data, it is important to keep the naming simple, so you know what file is what. All of these previous steps were necessary to delineate the watersheds, use (ArcToolbox $>$ Spatial Analyst $>$ Hydrology $>$ Watershed). For this, you will input streams, outlet points, and flow direction data. The last step is to convert the watershed raster to a polygon layer, which can be done using the Conversion Tools. You can play with the color options, or choose no color for the basins, so there is only an outline, overlaying your contours. Your file will look similar to the figure below. 


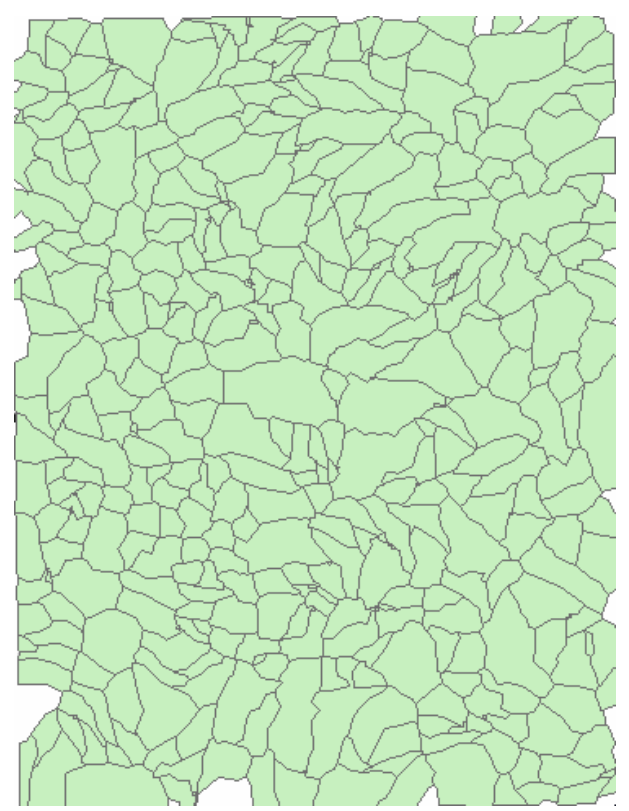

\section{Watershed Sub-Basins Layer}

To find the area of each basin, to use in runoff calculations, right click on the polygon layer of sub-basins, and click on Attribute Table. Create a new column, and label it "Area," then right click on the word Area and click "Calculate Geometry." You will now see the window below, and you can choose area, the data source, and the units you want to calculate the area in. When you click okay, you will see the values in the table.

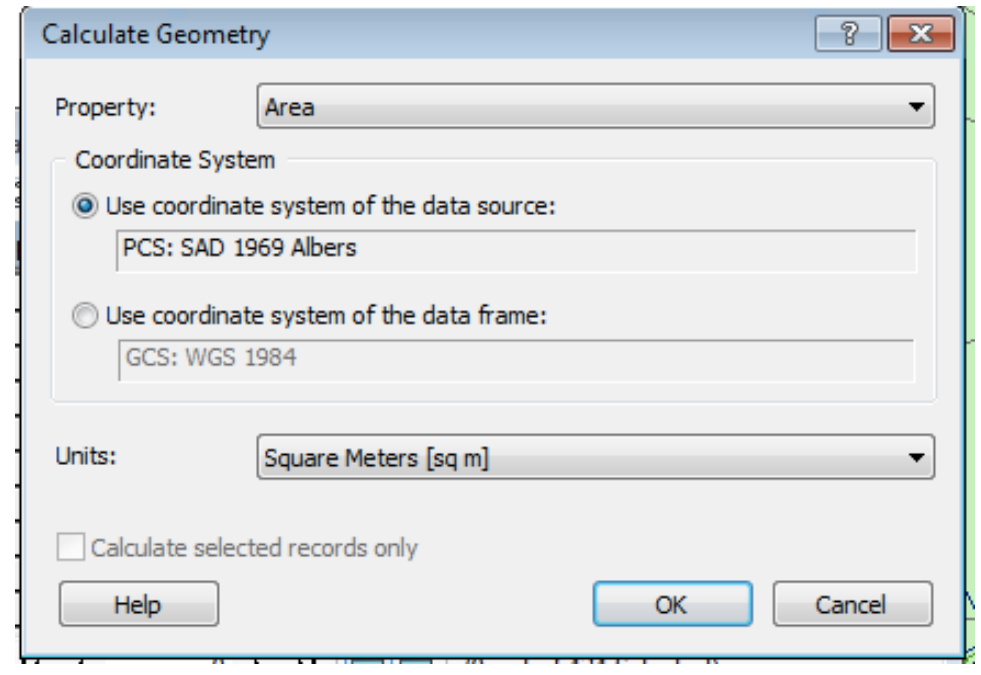

\section{Calculate Geometry Dialog Box}

Use the Layout View, which is the icon in the lower right-hand corner of the screen, to create publishable maps that include legends, north arrows, and map scales. There are many combinations, but in order to make a map, select the layers you would like to include, then go to Layout View and make it look however you want it to. You can 
always use the ArcGIS help feature, or simply use Google to find editing methods to create the right map for your needs. 


\section{Appendix B}

Canal Flow Rates in L/min

\begin{tabular}{|c|c|c|c|c|}
\hline & $100 \%$ full & $80 \%$ full & $50 \%$ full & $30 \%$ full \\
\hline Canals & $\mathrm{Q}(\mathrm{L} / \mathrm{min})$ & $\mathrm{Q}(\mathrm{L} / \mathrm{min})$ & $\mathrm{Q}(\mathrm{L} / \mathrm{min})$ & $\mathrm{Q}(\mathrm{L} / \mathrm{min})$ \\
\hline 1. San Pablo & 11900 & 8870 & 4640 & 2200 \\
\hline 2. Musk'a Pujhio & 2200 & 1660 & 890 & 430 \\
\hline 3.PaqchapataChute & 99670 & 70080 & 33000 & 16450 \\
\hline 4. Lower Paqchapata & 5760 & 4270 & 2200 & 1050 \\
\hline 5. Media Luna & 4040 & 3000 & 1600 & 770 \\
\hline 6. Pre-Inca & 5600 & 4180 & 2200 & 1050 \\
\hline 7. Inca Twin & 5600 & 4180 & 2200 & 1050 \\
\hline 8. Inca Diversion & 3100 & 2200 & 1200 & 460 \\
\hline 9. Bandolista Canal & 4480 & 3400 & 1800 & 920 \\
\hline 10. Bandolista Chute & 1840 & 1300 & 620 & 270 \\
\hline 11. Huaca Canal & 19800 & 14740 & 7700 & 3660 \\
\hline $\begin{array}{l}\text { 12. Manyaraqui } \\
\text { Canal }\end{array}$ & 82360 & 58400 & 27900 & 12000 \\
\hline
\end{tabular}


Canal Flow Rates in cfs

\begin{tabular}{|c|c|c|c|c|}
\hline & $100 \%$ full & $80 \%$ full & $50 \%$ full & $30 \%$ full \\
\hline Canals & $\mathrm{Q}(\mathrm{cfs})$ & $\mathrm{Q}(\mathrm{cfs})$ & $\mathrm{Q}(\mathrm{cfs})$ & $\mathrm{Q}(\mathrm{cfs})$ \\
\hline 1. San Pablo & 7.0 & 5.2 & 2.7 & 1.3 \\
\hline 2. Musk'a Pujhio & 1.3 & 1.0 & 0.5 & 0.3 \\
\hline 3.PaqchapataChute & 58.7 & 41.2 & 19.4 & 9.7 \\
\hline 4. Lower Paqchapata & 3.4 & 2.5 & 1.3 & 0.6 \\
\hline 5. Media Luna & 2.4 & 1.8 & 0.9 & 0.5 \\
\hline 6. Pre-Inca & 3.3 & 2.5 & 1.3 & 0.6 \\
\hline 7. Inca Twin & 3.3 & 2.5 & 1.3 & 0.6 \\
\hline 8. Inca Diversion & 1.8 & 1.3 & 0.6 & 0.3 \\
\hline 9. Bandolista Canal & 2.6 & 2.0 & 1.1 & 0.5 \\
\hline 10. Bandolista Chute & 1.1 & 0.8 & 0.4 & 0.2 \\
\hline 11. Huaca Canal & 11.7 & 8.7 & 4.5 & 2.2 \\
\hline $\begin{array}{l}\text { 12. Manyaraqui } \\
\text { Canal }\end{array}$ & 48.5 & 34.4 & 16.4 & 7.1 \\
\hline
\end{tabular}


Canal Flow Rates in L/s

\begin{tabular}{|c|c|c|c|c|}
\hline & $100 \%$ full & $80 \%$ full & $50 \%$ full & $30 \%$ full \\
\hline Canals & $\mathrm{Q}(\mathrm{L} / \mathrm{s})$ & $\mathrm{Q}(\mathrm{L} / \mathrm{s})$ & $\mathrm{Q}(\mathrm{L} / \mathrm{s})$ & $\mathrm{Q}(\mathrm{L} / \mathrm{s})$ \\
\hline 1. San Pablo & 198 & 148 & 77 & 37 \\
\hline 2. Musk'a Pujhio & 37 & 28 & 15 & 7 \\
\hline 3.PaqchapataChute & 1661 & 1168 & 550 & 274 \\
\hline 4. Lower Paqchapata & 96 & 71 & 37 & 18 \\
\hline 5. Media Luna & 67 & 50 & 27 & 13 \\
\hline 6. Pre-Inca & 93 & 70 & 37 & 17 \\
\hline 7. Inca Twin & 93 & 70 & 37 & 17 \\
\hline 8. Inca Diversion & 52 & 37 & 17 & 8 \\
\hline 9. Bandolista Canal & 75 & 57 & 31 & 15 \\
\hline 10. Bandolista Chute & 31 & 22 & 10 & 5 \\
\hline 11. Huaca Canal & 330 & 246 & 128 & 61 \\
\hline 12. Manyaraqui Canal & 1373 & 973 & 465 & 200 \\
\hline
\end{tabular}




\section{Appendix C}

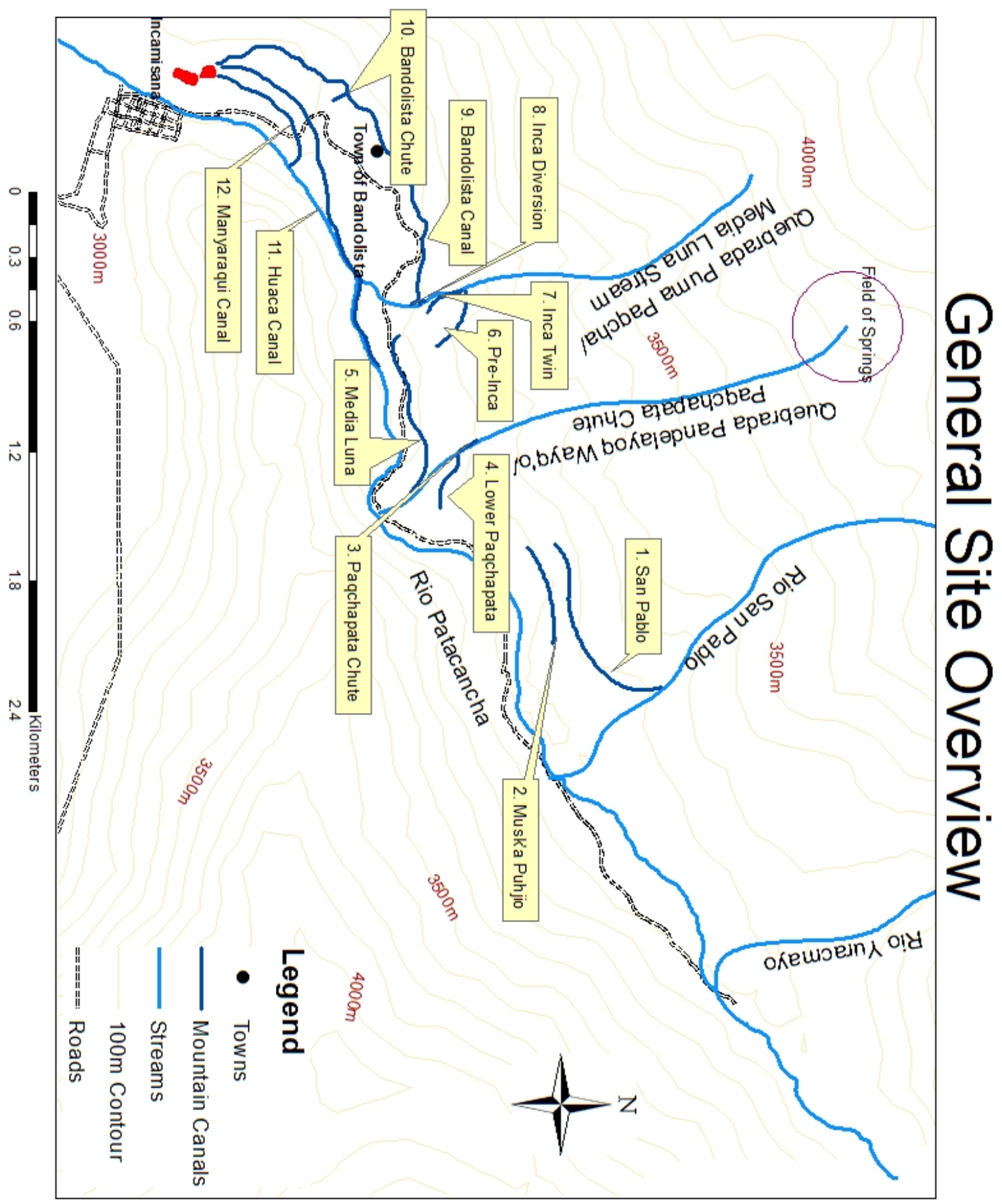




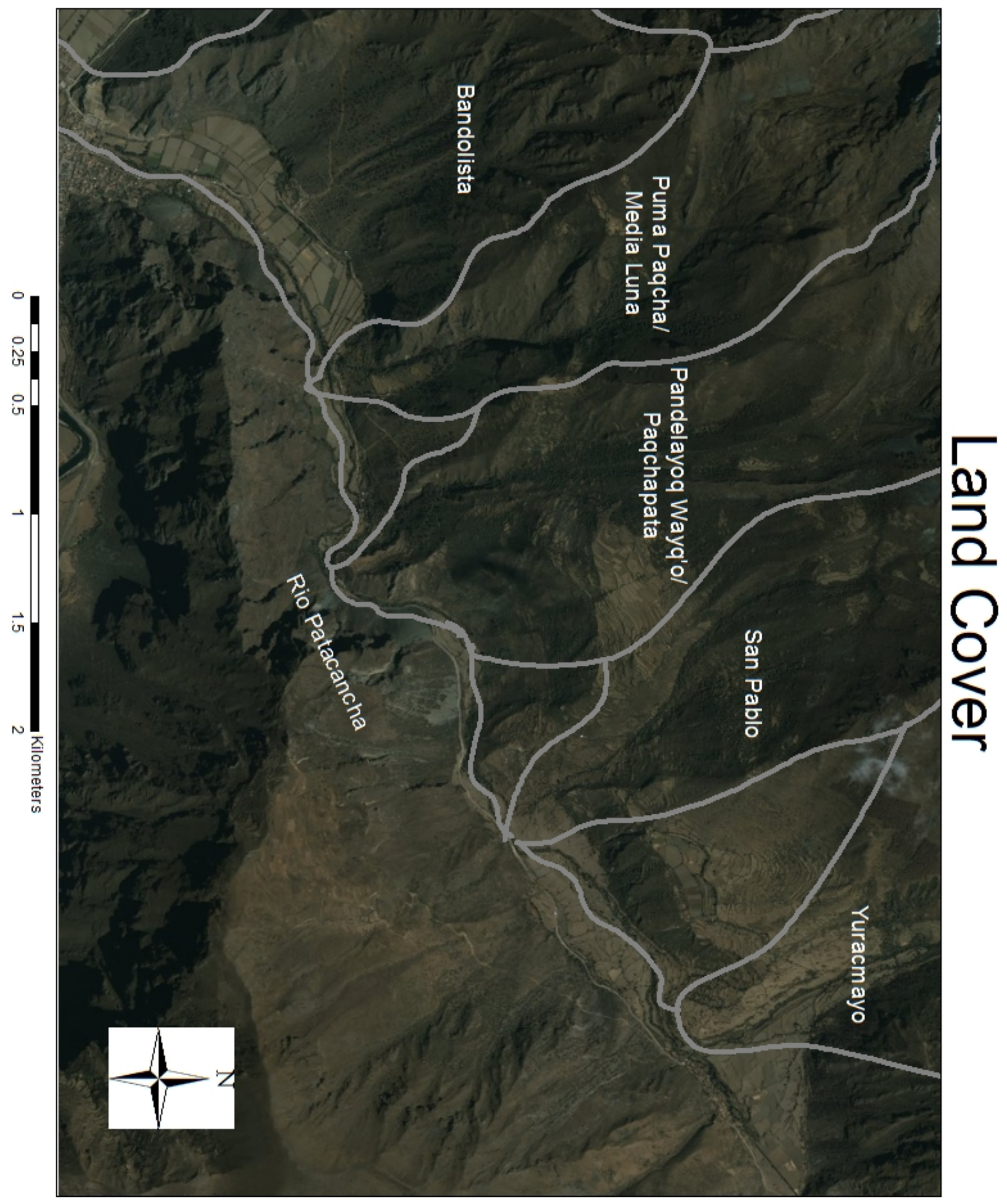




\section{Incamisana Watershed}

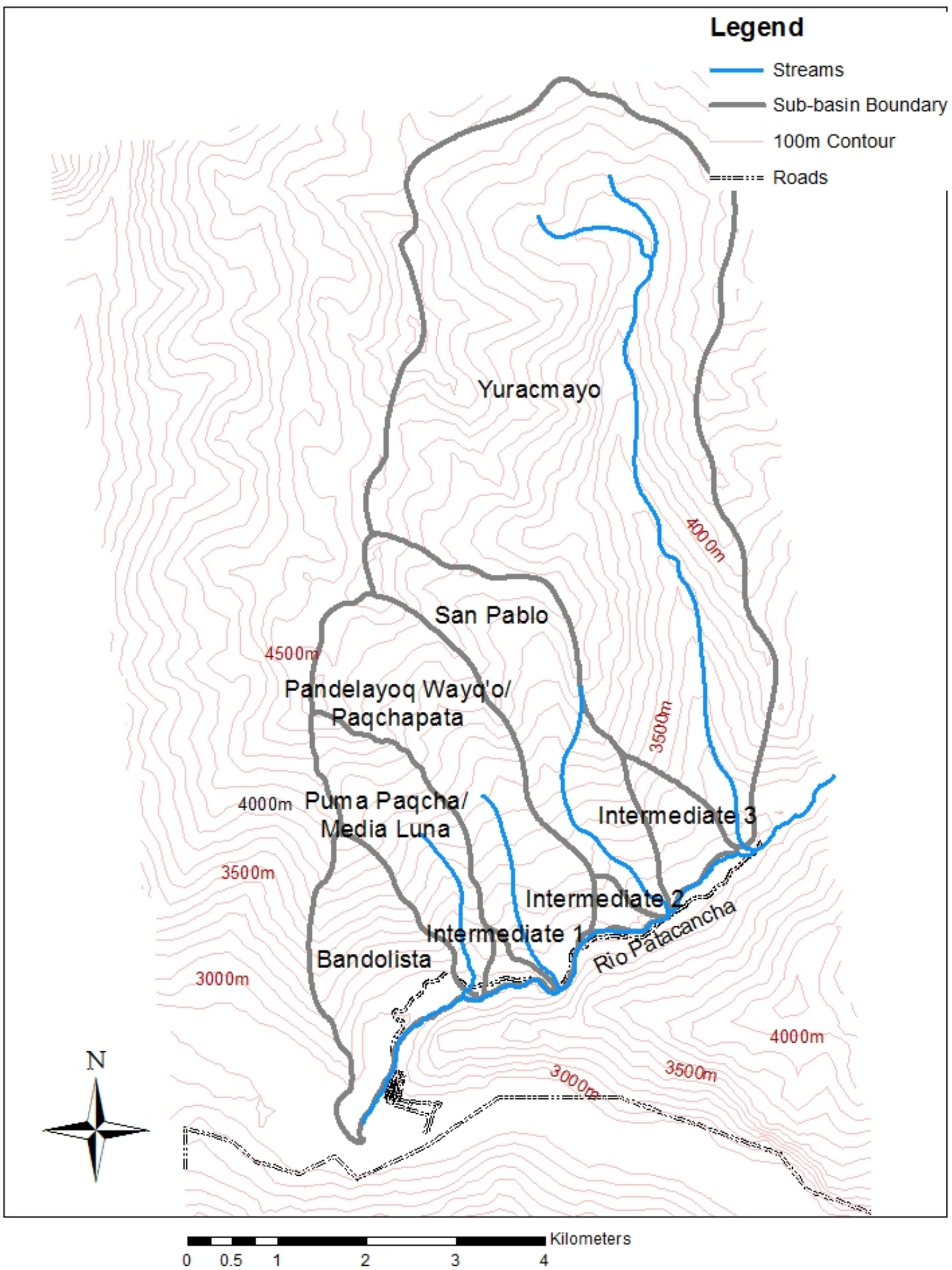




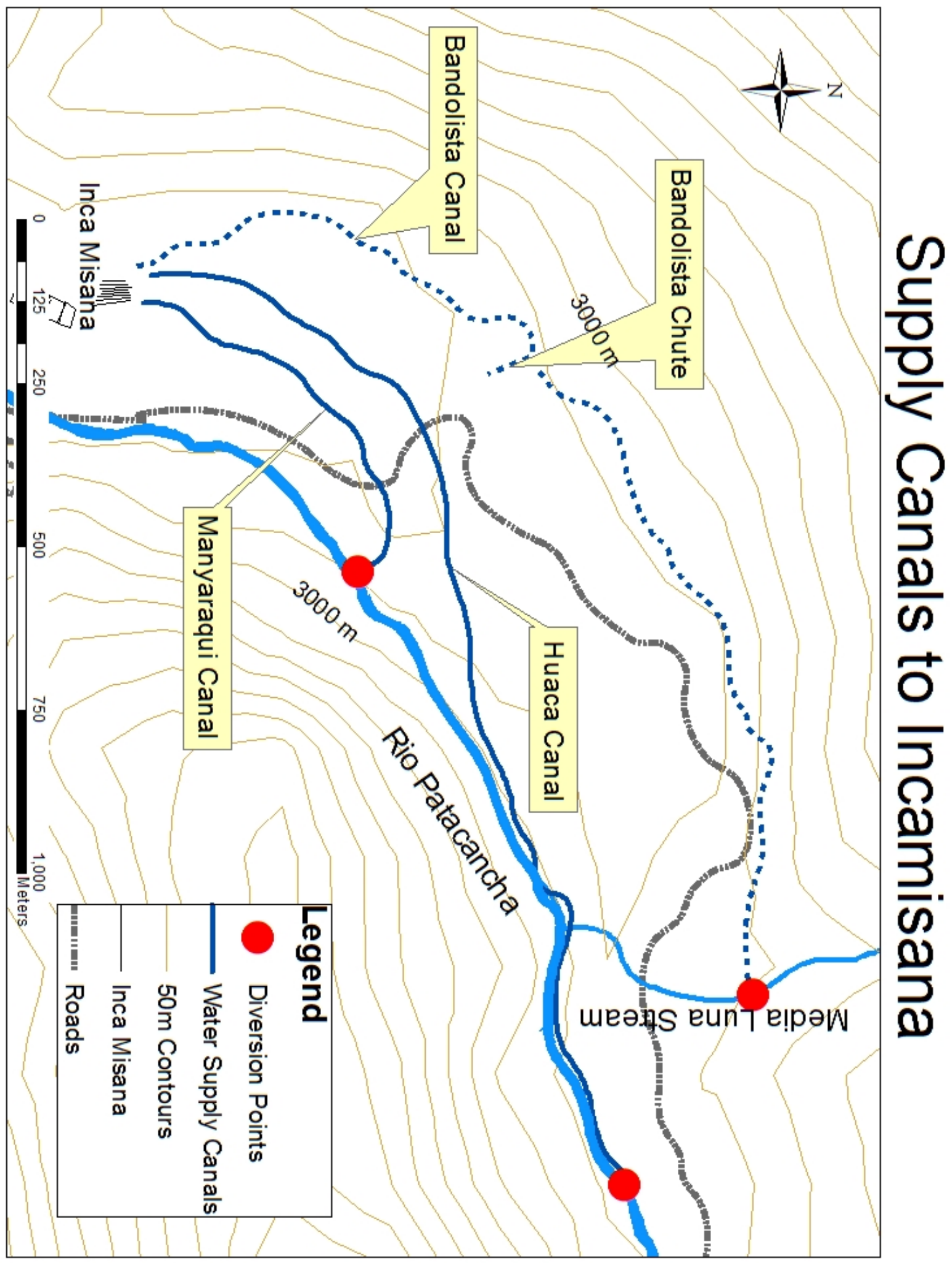




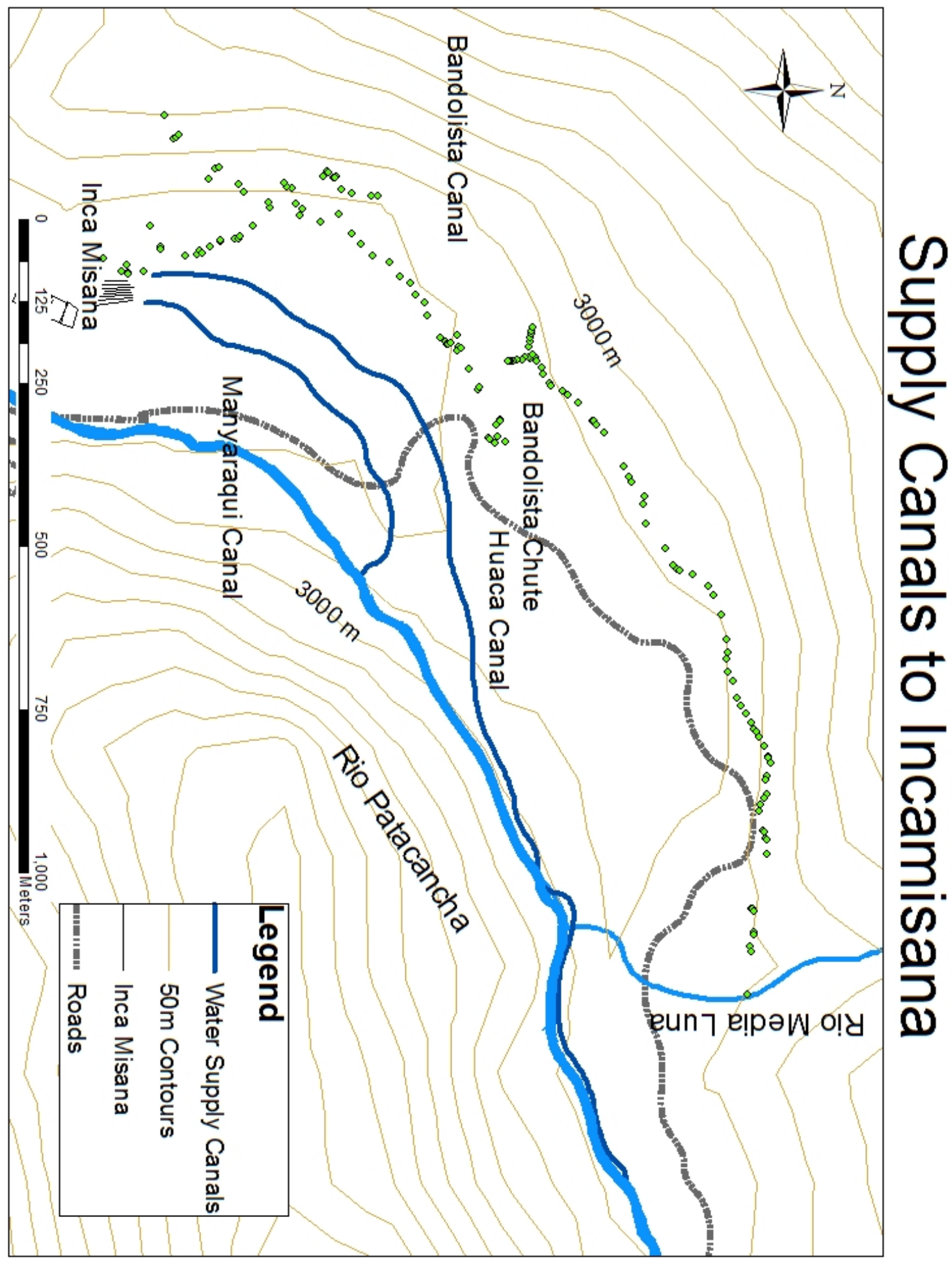




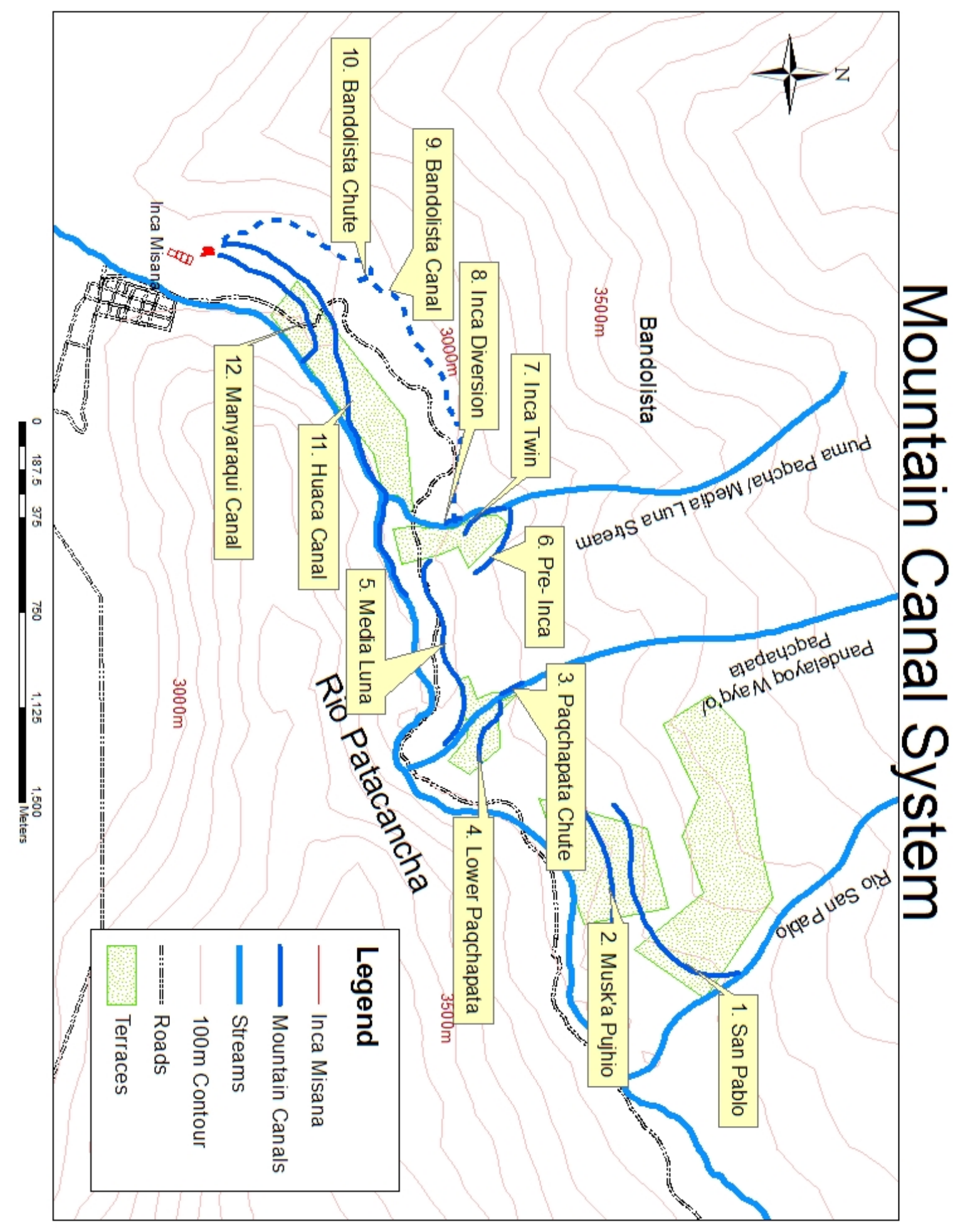




\section{Incamisana Watershed}

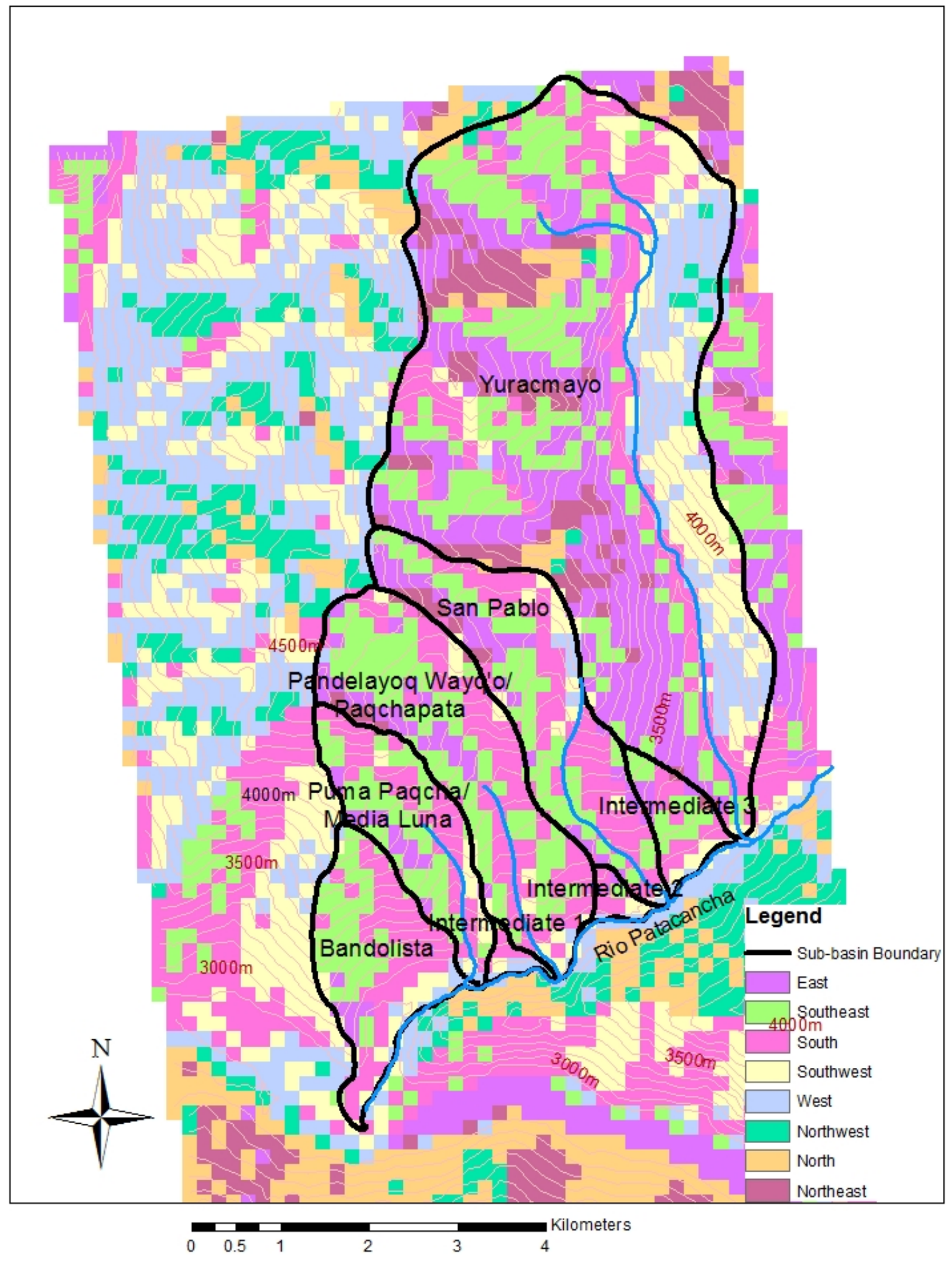




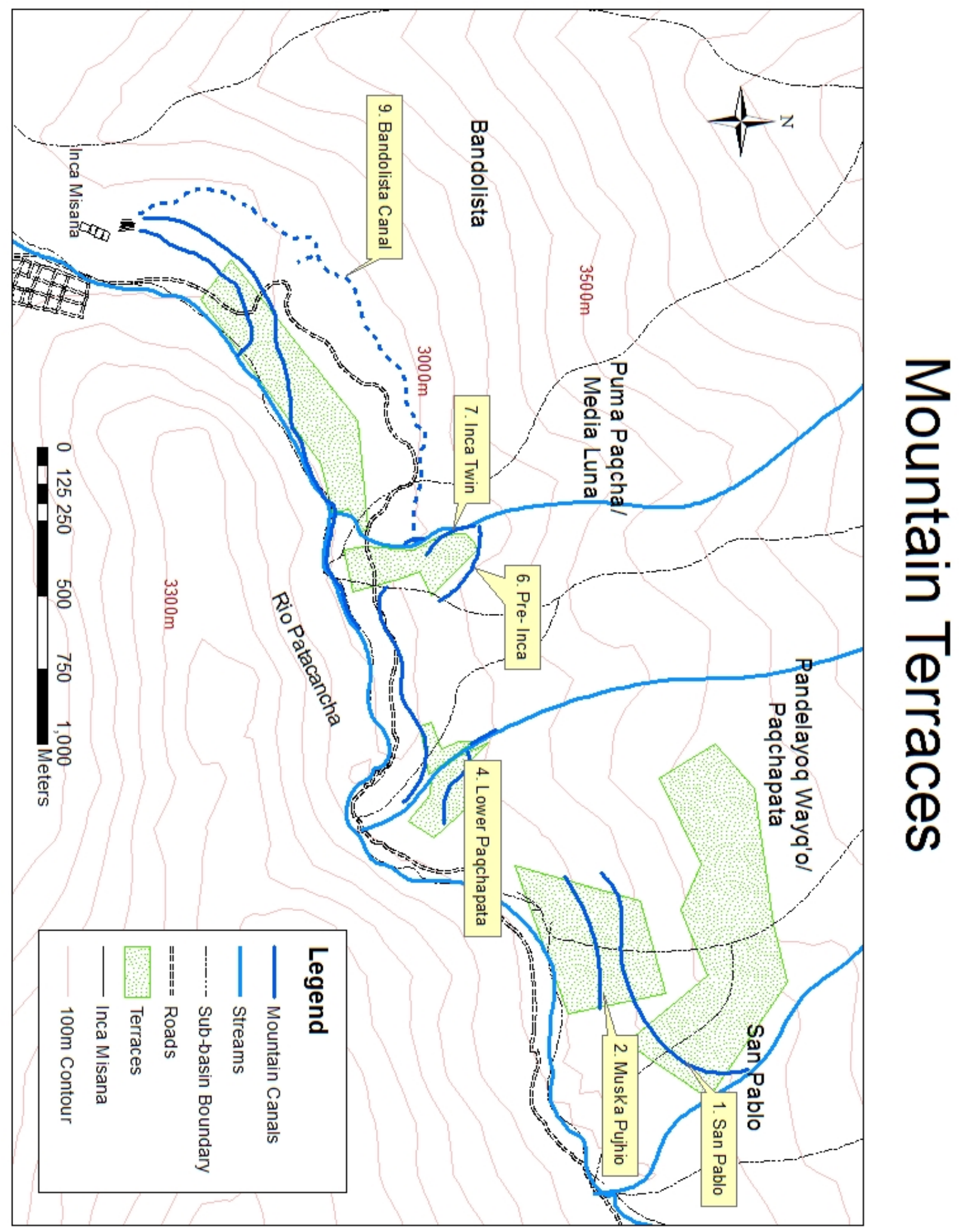

